\author{
UNIVERSIDADE DE SÃO PAULO \\ Faculdade de Ciências Farmacêuticas \\ Programa de Pós-Graduação em Fármacos e Medicamentos \\ Área de Produção e Controle de Fármacos
}

\title{
Avaliação ex vivo da inibição da peroxidação lipídica do estrato córneo promovida por filtros UVB
}

\author{
Paulo Vitor Gonçalves
}

Dissertação para a defesa do Título de

Mestre

Orientador:

Prof. Dr. André Rolim Baby

São Paulo

2019 


\author{
UNIVERSIDADE DE SÃO PAULO \\ Faculdade de Ciências Farmacêuticas \\ Programa de Pós-Graduação em Fármacos e Medicamentos \\ Área de Produção e Controle de Fármacos
}

\title{
Avaliação ex vivo da inibição da peroxidação lipídica do estrato córneo promovida por filtros UVB
}

\author{
Paulo Vitor Gonçalves
}

Versão Corrigida

Dissertação para a defesa do Título de

Mestre

Orientador:

Prof. Dr. André Rolim Baby

São Paulo

2019 
Ficha Catalográfica elaborada eletronicamente pelo autor, utilizando o programa desenvolvido pela Seção Técnica de Informática do ICMC/USP e adaptado para a Divisão de Biblioteca e Documentação do Conjunto das Químicas da USP

Bibliotecária responsável pela orientação de catalogação da publicação: Marlene Aparecida Vieira - CRB - 8/5562

Gonçalves, Paulo Vitor

Avaliação ex vivo da inibição da peroxidação lipídica do estrato córneo promovida por filtros UVB / Paulo Vitor Gonçalves. - São Paulo, 2019. $57 \mathrm{p}$.

Dissertação (mestrado) - Faculdade de Ciências Farmacêuticas da Universidade de São Paulo. Departamento de Farmácia. Orientador: Baby, Andre Rolim Baby

1. Peroxidação lipídica. 2. Ensaio ex vivo. 3. Malondialdeído. 4. TBARS. 5. Fotoproteção. I. T. II. Baby, Andre Rolim Baby, orientador. 
Paulo Vitor Gonçalves

Avaliação ex vivo da inibição da peroxidação lipídica do estrato córneo promovida por filtros UVB

Comissão Julgadora

da

Dissertação para obtenção do Título de Mestre

Prof. Dr. André Rolim Baby

Orientador / Presidente

$1^{\circ}$ examinador

$2^{\circ}$ examinador

$3^{\circ}$ examinador

São Paulo, de 


\section{DEDICATÓRIA}

Aos meus pais, Elcio e Maria Helena.

Aos meus irmãos, Luana e Guilherme.

Ao meu primo irmão Luis Henrique.

A minha amiga e namorada Kasia.

Às minhas tias, Rachel e Maria Teresa.

Ao meu orientador e amigo,

Prof. Dr. André Rolim Baby. 


\section{EPÍGRAFE}

How many roads must a man walk down

Before you call him a man?

How many seas must a white dove sail

Before she sleeps in the sand?

Yes, and how many times must the cannon balls fly

Before they're forever banned?

The answer, my friend, is blowin' in the wind The answer is blowin' in the wind" Blowin' In The Wind - Bob Dylan 


\section{AGRADECIMENTOS}

A todos os professores e professoras do Programa de Pós-Graduação em Fármacos e Medicamentos, que muito me ensinaram durante as disciplinas e reuniões. Em especial aos queridos Professores Dr. Paulo Chanel, Dr. Paulo Moreno e Dr. Felipe Rebello.

Ao meu orientador, amigo e mentor Professor André Rolim Baby, por compartilhar conhecimentos pessoais e profissionais. Especialmente pela confiança e carinho depositados durante esta árdua jornada.

Aos técnicos e amigos, Claudinéia e Edgar, pela atenção, dedicação e carinho.

Aos companheiros de laboratório e amigos Alberto, Amanda, André, Andressa, Camila Areias, Camila, Letícia, Daniele, Kamilla, Edilson, Fabiana, Felipe, Gabriela, Ingrid, Jesus, Michelli, Nadia, Rafael, Rebbeca, Tércio, Thalita, Thamires, Thomas, Victória e Yasmin.

Aos meus amigos e parceiros Fernandão, Cláudio e Luis Xoia.

Aos funcionários da FCF-USP, David, Alexandre, Irineu, Sueli, Dorinha e Jorge.

\section{À empresa BASF.}

À Faculdade de Ciências Farmacêuticas da Universidade de São Paulo, pelo acolhimento, estrutura e ensinamentos.

Ao CNPq, CAPES e FAPESP, pelos auxílios financeiros, diretos e indiretos, para a realização desta pesquisa.

etapa.

E a todos que contribuíram de alguma forma, para a conclusão desta 


\section{RESUMO}

GONÇALVES, P.V. Avaliação ex vivo da inibição da peroxidação lipídica do estrato córneo promovida por filtros UVB. 2018. 57p (Dissertação de Mestrado). Faculdade de Ciências Farmacêuticas, Universidade de São Paulo, São Paulo, 2018.

O aumento da incidência do câncer de pele está associado à maior exposição à luz solar e a adoção de ações de proteção ao Sol é uma estratégia para minimizar os níveis cumulativos de danos à pele. Os raios ultravioletas (UV), ao alcançarem o tecido cutâneo, podem causar eritema, inflamação, fotoenvelhecimento, formação de rugas e imunossupressão, entre outros, devido à formação de espécies reativas de oxigênio (ERO's). A formação de ERO's, como o oxigênio singleto, radical ânion superóxido, peróxido de hidrogênio e radical hidroxil, elevam o risco dos danos foto-oxidativos. O desequilíbrio entre a formação de ERO's e os mecanismos antioxidantes do organismo desencadeia o estresse oxidativo. Na pele, as ERO's são as responsáveis pelo dano oxidativo no DNA, proteínas e lipídeos. Identificar e quantificar biomarcadores do estresse oxidativo cutâneo é essencial para a correlação entre os raios UV e seus efeitos. Deve-se isto, em parte, à limitação de métodos para quantificar os parâmetros que são diretamente afetados pela exposição aos raios UV, tais como a peroxidação lipídica. São necessários métodos complementares para avaliação da eficácia de fotoprotetores perante os danos causados por este tipo de estresse. Esta pesquisa projeto compreendeu a avaliação ex vivo da eficácia de filtros solares UVB por meio da quantificação da peroxidação lipídica proveniente do estrato córneo removido por tape stripping. Foram preparados sistemas emulsionados do tipo O/A com os filtros octocrileno, metoxicinamato de octila e salicilato de octila. A caracterização funcional da eficácia fotoprotetora in vitro demonstrou que o filtro octocrileno manteve-se estável, mesmo após exposição solar artificial. Os filtros octocrileno $(10 \% \mathrm{p} / \mathrm{p})$, metoxicinamato de octila $(10 \% \mathrm{p} / \mathrm{p})$ e salicilato de octila $(5 \% \mathrm{p} / \mathrm{p})$ alcançaram, após irradiância, respectivamente, os valores de FPS 5,7 \pm 2,$1 ; 4,7 \pm 1,5$ e 1,0 0,0 . As formulações foram utilizadas na avaliação da eficácia fotoprotetora ex vivo. O método por CLAE, para quantificação da peroxidação lipídica no estrato córneo, possuiu linearidade e demonstrou exatidão e precisão satisfatórias. $O$ estresse pela radiação UV desencadeou a peroxidação lipídica no estrato córneo. Em função do protocolo aplicado, não houve diferenças entre as amostras. A eficácia, com relação à inibição da peroxidação lipídica, foi similar em todas as amostras.

Palavras-chave: TBARS, peroxidação lipídica, ex vivo, filtro solar UVB. 


\section{ABSTRACT}

GONÇALVES, P.V. Ex vivo evaluation of the inhibition of lipid peroxidation of the stratum corneum promoted by UVB filters. 2018. 57p (Dissertação de Mestrado). Faculdade de Ciências Farmacêuticas, Universidade de São Paulo, São Paulo, 2018.

The increasing of incidence of skin cancer is associated with greater exposure to sunlight and the adoption of sun protection actions is a strategy to minimize cumulative levels of skin damage. Ultraviolet (UV) rays, when they reach the cutaneous tissue, can cause erythema, inflammation, photoaging, wrinkling and immunosuppression, among other things, due to the formation of reactive oxygen species (ROS). The formation of ROS, such as singlet oxygen, superoxide anion radical, hydrogen peroxide and hydroxyl radical, raise the risk of photooxidative damage. The variation between the formation of ROS and the antioxidant mechanisms of the organism triggers oxidative stress. In the skin, ROS are responsible for oxidative damage in DNA, proteins and lipids. Identifying and quantifying biomarkers of cutaneous oxidative stress is essential for the correlation between UV rays and their effects. This is partially due to the limitation of methods for quantifying parameters that are directly affected by exposure to UV rays, such as lipid peroxidation. Complementary methods are needed to evaluate the effectiveness of photoprotectors because of the damage caused by this type of stress. This research project had the ex vivo evaluation of the efficacy of UVB sunscreens by quantifying the lipid peroxidation from the stratum corneum removed by tape stripping. Emulsified O/A type systems were prepared with the octocrylene, octyl methoxycinnamate and octyl salicylate filters. The functional characterization of photoprotective efficacy in vitro revealed that the octocrylene filter remained stable even after artificial sun exposure. Octocrylene $(10 \% \mathrm{w} / \mathrm{w})$, octyl methoxycinnamate $(10 \% \mathrm{w} / \mathrm{w})$ and octyl salicylate $(5 \% \mathrm{w} / \mathrm{w})$ respectively reached the values of FPS $5.7 \pm 2.1 ; 4.7 \pm 1.5$ and $1.0 \pm 0.0$. The formulations were used in the evaluation of ex vivo photoprotective efficacy. The method by HPLC, for quantification of the lipid peroxidation in the stratum corneum, had linearity and demonstrated satisfactory accuracy and precision. UV radiation stress triggered lipid peroxidation in the stratum corneum. Due to the protocol applied, there were no differences between the samples. The efficacy, compared to the inhibition of lipid peroxidation, was similar in all samples.

Keywords: TBARS, lipid peroxidation, ex vivo, UVB filters. 


\section{RELAÇÃO DE FIGURAS}

Figura 1. Intensidade da radiação solar e UV (RODRIGUES, STANIFORTH, STAVROS, 2017).

Figura 2. Efeitos da radiação UV na pele (SVOBODOVA et al., 2006)..................5

Figura 3. Estrutura molecular do MCO (ZAMBON, 2011) .................................

Figura 4. Espectro do octocrileno em UV-visível (POLONINI et al., 2014)............9

Figura 5. Estrutura molecular do octocrileno (BAKER, HORBURY, STAVROS; 2016).

Figura 6. Estrutura geral dos salicilatos (RIBEIRO, 2004). 10

Figura 7. Formação do MDA e do HNE por degradação de acido graxo poliinsaturado.

Figura 8. Reação do MDA após o processo de peroxidação lipídica (ALONSO et al., 2009). .14

Figura 9. Área de demarcação das fitas nos antebraços. .28

Figura 10. representação das áreas de demarcação e aplicação no voluntário. .28

Figura 11. Curva analítica do aduto MDA-TBA. 37

Figura 12. Cromatogramas individualmente sobrepostos dos interferentes do ensaio de TBARS. 39

Figura 13. Gráfico de valores Individuais dispersos de concentração pela condição.

Figura 14. Gráfico de comparação entre as médias das amostras com os valores individuais dispersos por grupo, somente amostras irradiadas.

Figura 15. Deslocalização e ligação de hidrogênio através do plano da estrutura geral dos salicilatos.

Figura 16. Deslocalização de elétron em molécula de cinamato. .45 


\section{RELAÇÃO DE QUADROS}

Quadro 1. Principais filtros UV utilizados em fotoprotetores (LOPES, CRUZ,

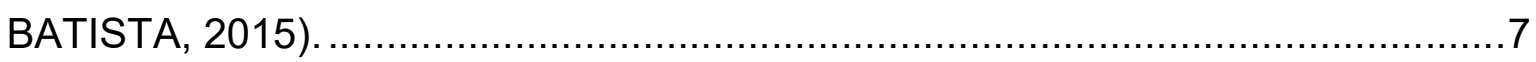

Quadro 2. Equipamentos utilizados nesta pesquisa................................. 17

Quadro 3. Matérias-primas e solventes utilizados na pesquisa.......................18

Quadro 4. Fototipos de pele segundo Fitzpatrick (FITZPATRICK, 1988)...........27 


\section{RELAÇÃO DE TABELAS}

Tabela 1. Concentrações de filtros nas formulações fotoprotetoras. 19

Tabela 2. Composição qualitativa e quantitativa (\%p/p) das formulações fotoprotetoras.

Tabela 3. Precisão esperada em função da concentração do analito na amostra25

Tabela 4. Recuperação esperada em função da concentração do analito na amostra .26

Tabela 5. Testes de centrifugação e estresse térmico aplicado as formulações fotoprotetoras.

Tabela 6. Características organolépticas e físico-químicas das formulações fotoprotetoras.

Tabela 7. Valores de FPS e comprimento de onda crítico in vitro das formulações fotoprotetoras.

Tabela 8. Dados utilizados na construção da curva analítica. .36

Tabela 9. Linearidade de acordo com a análise da regressão .37

Tabela 10. Áreas dos picos e média utilizados na precisão. 38

Tabela 11. Recuperação das concentrações do aduto MDA-TBA. .40

Tabela 12. Média das concentrações de adutos MDA-TBA nas amostras de tape stripping, do estrato córneo da pele sem formulação

Tabela 13. Concentração média do aduto MDA-TBA nas amostras. .43

Tabela 14. Resultados de FPS, comprimento de onda crítico e concentração do aduto MDA-TBA e valores de coeficiente de extinção molar da literatura. .46 


\section{EQUAÇÕES}

Equação 1. Fator de Proteção Solar in vitro (FPS estimado)...........................21

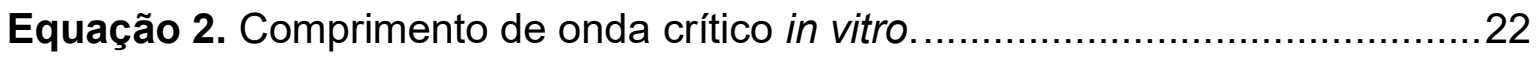

Equação 3. Precisão, calculada como desvio padrão relativo (DPR, \%). ............25

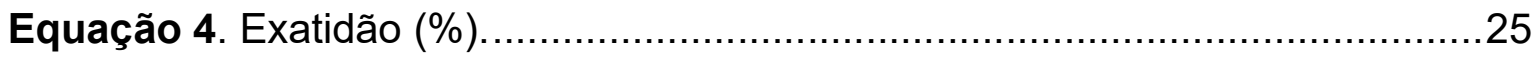




\section{LISTA DE ABREVIATURAS}

CLAE - Cromatografia à líquido de alta eficiência

COLIPA - The European Cosmetic and Perfumery Association

DNA - Ácido desoxirribonucleico

EC - Estrato Córneo

ERO's - Espécies reativas de oxigênio

HNE - 4-Hydroxynonenal

HOMO - Orbital molecular ocupado de maior energia

$\log \mathrm{P} \quad-\quad$ Coeficiente de partição

LUMO - Orbital desocupado de menor energia

MDA - Malondialdehyde

OCT - Octocrileno

MCO - Metoxicinamato de octila

PGE2 - Prostaglandina E2

RDC - Resolução da Diretoria Colegiada

TBA - Thiobarbituric acid

TBARS - Thiobarbituric acid reactive substances

USA - United States of America

UV - Ultravioleta

UVB - Ultravioleta B

$\lambda \quad-\quad$ Comprimento de onda 


\section{SUMÁRIO}

1. INTRODUÇÃO

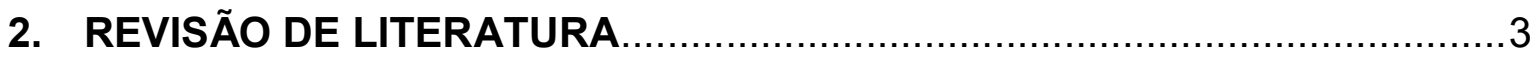

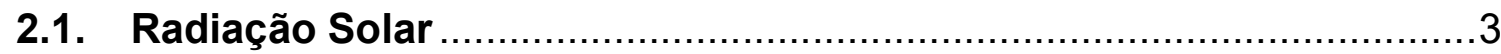

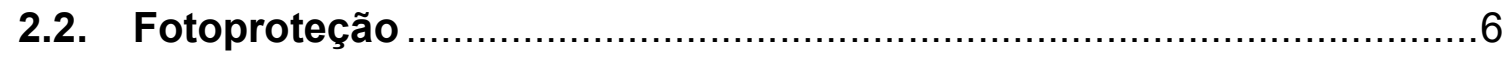

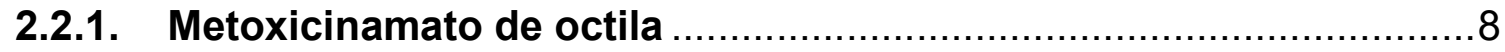

2.2.2. Octocrileno

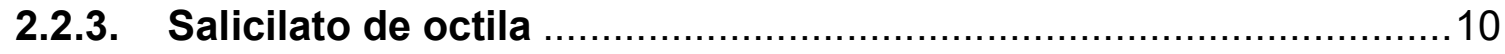

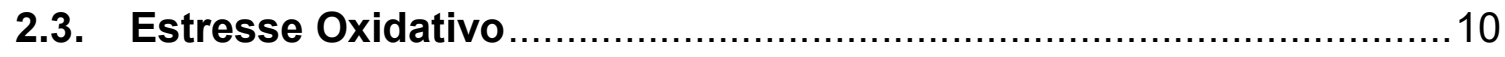

2.4. Ensaio do ácido tiobarbitúrico (TBARS) ………..........................11

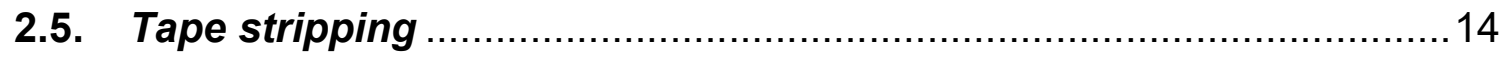

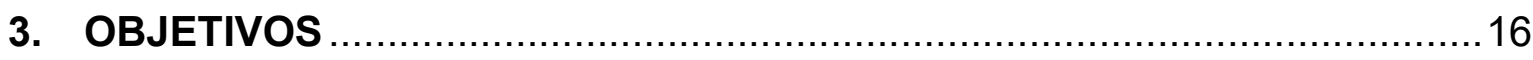

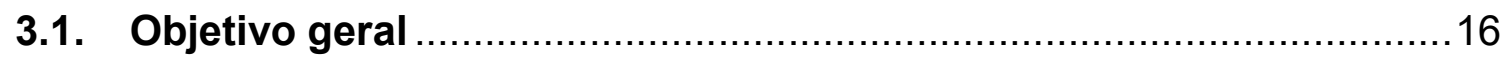

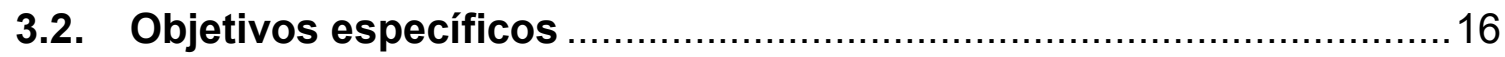

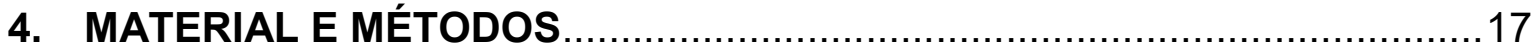

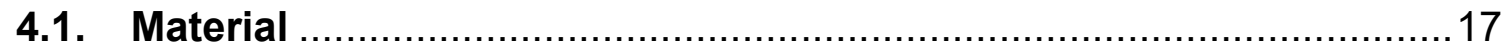

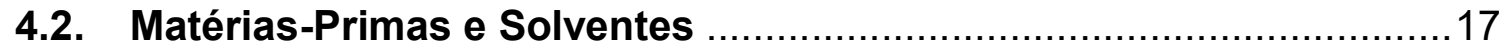

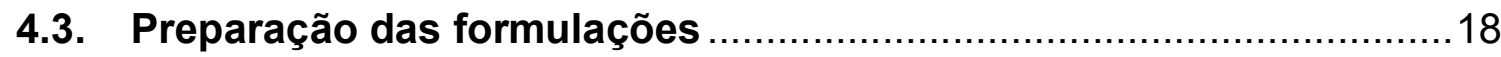

4.4. Estudo de Estabilidade Preliminar das formulações .........................20

4.5. Determinação do valor $\mathrm{pH}$ e das características organolépticas das

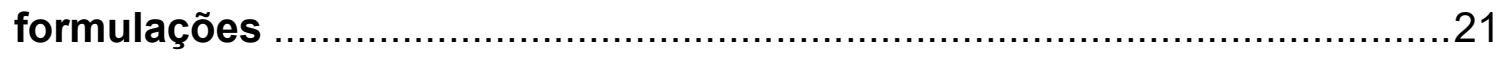

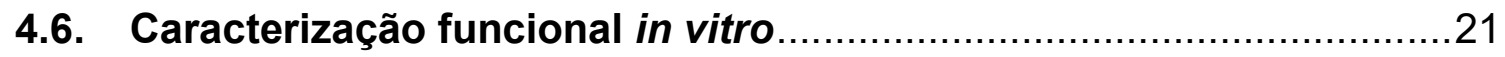

4.7. Espécies reativas do ácido tiobarbitúrico ………………..............22

4.7.1. Preparação da solução estoque de MDA ………….......................22

4.7.2. Método analítico para a quantificação do aduto dialdeído malônico

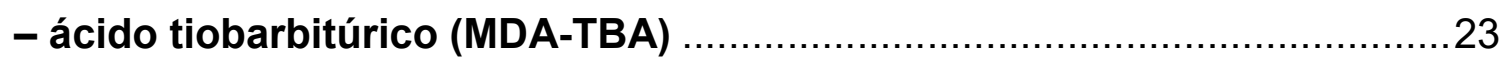

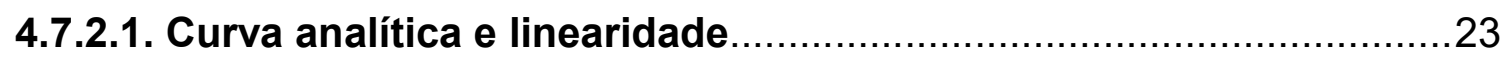

4.7.2.2. Especificidade e pesquisa de interferentes 23 
4.7.2.3. Precisão .24

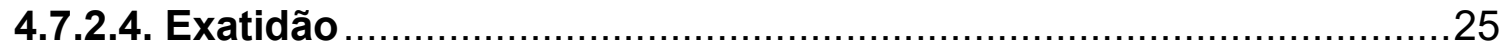

4.8. Ensaio ex vivo - Aspectos legais e éticos .................................26

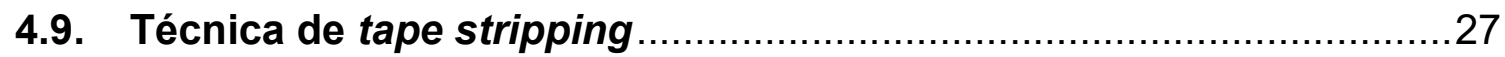

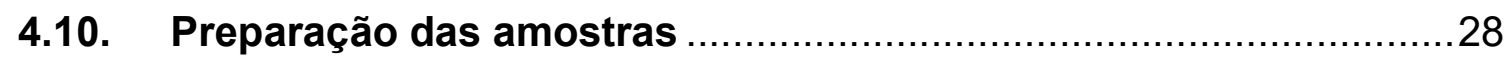

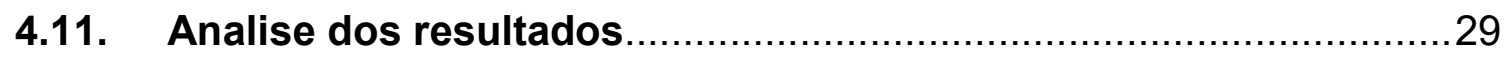

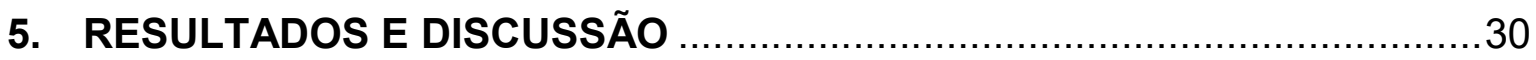

5.1. Preparação das formulações fotoprotetoras ............................... 30

5.2. Estudo de Estabilidade Preliminar das formulações fotoprotetoras 30

5.3. Determinação do valor de pH e das características organolépticas

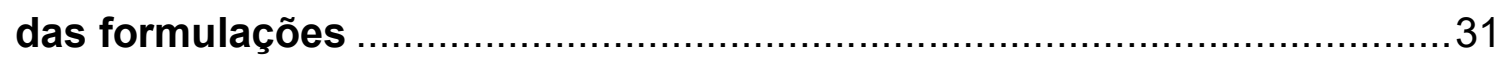

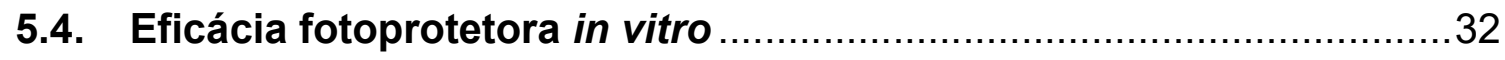

5.5. Método analítico para a quantificação do aduto dialdeído malônico -

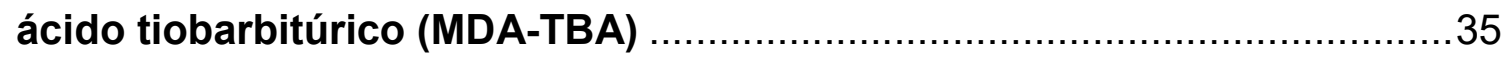

5.5.1. Curva analítica e Linearidade ........................................... 35

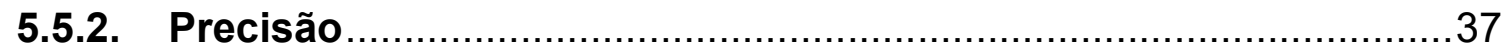

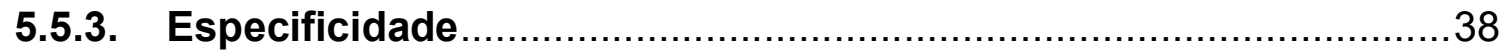

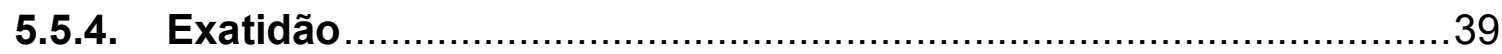

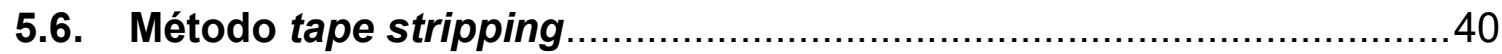

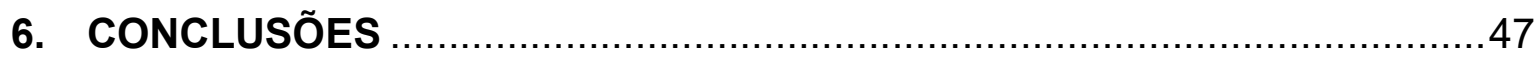

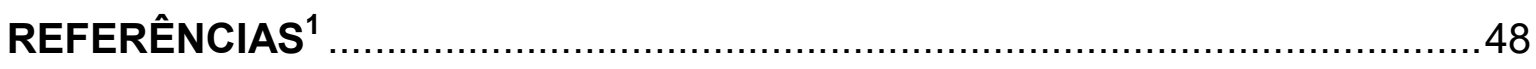

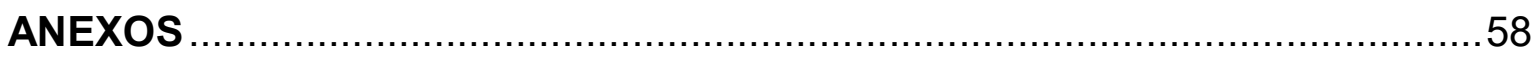




\section{INTRODUÇÃO}

A pele estabelece o limite entre o organismo interno humano e o ambiente, impedindo a perda excessiva de água e a ação de fatores externos, dentre mais funções. As principais funções da pele estão relacionadas com diferentes tipos de proteção: física, química, imunológica, contra radiação ultravioleta (UV) e espécies reativas de oxigênio (ERO's). A epiderme, camada mais externa, é composta basicamente de queratinócitos (90\%) e é rica em antioxidantes, como: superóxido dismutase, catalase, tioredoxina redutase, glutationa peroxidase e antioxidantes de baixo peso molecular, a saber, o tocoferol, a glutationa e o ácido ascórbico. Estes são a proteção natural da pele contra o estresse oxidativo, porém, sob os efeitos excessivos e crônicos à radiação UV, tornam-se insuficientes (ALONSO et al., 2009; BABY, 2007; BABY et al., 2009; NATARAJAN et al., 2014; THIELE et al., 2001).

Está estabelecido que, em excesso, a formação de ERO's é intrínseca à inflamação e a consequente produção de peróxidos lipídicos, provocando o estresse oxidativo. Na pele, a peroxidação lipídica induzida por UV aumenta a produção de prostaglandinas (PGE2), as quais desencadeiam a reação inflamatória. Os eventos associados aos danos causados pelos raios UV podem promover a imunossupressão, envelhecimento precoce e câncer de pele (ALONSO et al., 2009; BASTOS et al., 2012; LEVI, 2013).

Métodos de fotoproteção incluem evitar a exposição solar durante os períodos de maior incidência de radiação, utilizar vestimentas adequadas e usar fotoprotetores. Para prevenir e proteger contra os danos causados pela radiação solar, os protetores solares, fotoprotetores, são a principal abordagem (BABY et al., 2008; BALOGH et al., 2011; OLIVEIRA et al., 2015; VELASCO et al., 2008).

Estudos demonstraram estratégias antioxidantes, associadas aos fotoprotetores, como medida que previne a peroxidação lipídica e a desnaturação de proteínas da pele. $\mathrm{O}$ acúmulo de antioxidantes na epiderme, por meio do uso tópico, tem demonstrado importante função contra os fotodanos UV-induzidos. Estes danos oxidativos, de lipídeos e proteínas, ocorrem por meio de reações fotoquímicas como consequência imediata da exposição aos raios UV. A peroxidação lipídica na pele surge como resultado destes danos foto-oxidativos (IKEHATA, ONO, 2011; OLIVEIRA, 2015; PERES, 2015; RIBEIRO et al., 2006). 
Estratégias para prevenir e proteger contra os danos causados pela exposição solar estão se expandindo, porém, a eficácia destas pode ser insatisfatória. Identificar e quantificar biomarcadores do estresse oxidativo na pele é essencial para a correta correlação entre os raios UV e seus efeitos. Existe ampla investigação sobre os efeitos de danos UV e tratamentos à nível celular, entretanto, há diferentes métodos de quantificar estes efeitos induzidos por UV na pele. Deve-se isto, em parte, à falta de métodos para quantificar os parâmetros que são diretamente afetados pela exposição aos raios $U V$, tais como a peroxidação de lipídeos, alteração na quantidade de antioxidantes, atividade de enzimas antioxidantes e produtos da oxidação de proteínas e do DNA (GILBERT et al., 2013; LEVI, 2013; NATARAJAN et al., 2014). Portanto, apesar do uso de protetores solares ser uma realidade irretorquível, existe a necessidade de métodos complementares para a comprovação mais abrangente da eficácia desta classe de produtos. São necessários métodos para avaliação da eficácia de fotoprotetores perante os danos causados pelo estresse oxidativo.

O presente projeto envolveu o preparo de formulações fotoprotetoras contento filtros UVB. Foi realizada a avaliação da eficácia fotoprotetora in vitro e desenvolvido um método de avaliação da eficácia fotoprotetora ex vivo por meio da técnica de tape stripping. O novo método visou quantificar o quão os filtros UVB impedem a lipoperoxidação através do ensaio do ácido tiobarbitúrico (TBARS) por cromatografia à líquido de alta eficiência (CLAE). 


\section{REVISÃO DE LITERATURA}

\subsection{Radiação Solar}

Devido à degradação da camada de ozônio, o aumento da incidência de câncer de pele está associado à maior exposição à luz solar e a inclusão de ações de proteção ao sol é um meio relevante de minimizar os níveis cumulativos de exposição à radiação (CHANG et al., 2010; COLIPA, 2006; URASAKI et al., 2016).

O espectro contínuo de radiação eletromagnética, que compõe a luz solar, está dividido conforme o comprimento de onda $(\lambda)$ : infravermelho $(>780$ $\mathrm{nm})$, visível (780-400 nm) e radiação ultravioleta (UV) (400-100 nm). Didaticamente, a radiação UV está dividida em UVC (100-290 nm), UVB (290-320 nm), UVA II (320-340 nm) e UVA I (340-400 nm). A radiação UV está classificada de acordo com a Figura 1, sendo a sua intensidade destacada antes e após atingir a atmosfera terrestre (BALOGH et al., 2011; NASCIMENTO, SANTOS, AGUIAR, 2013; RODRIGUES, STANIFORTH, STAVROS, 2017; U.S., 2015a; U.S., 2015b). 
Figura 1. Intensidade da radiação solar e UV (RODRIGUES, STANIFORTH, STAVROS, 2017).

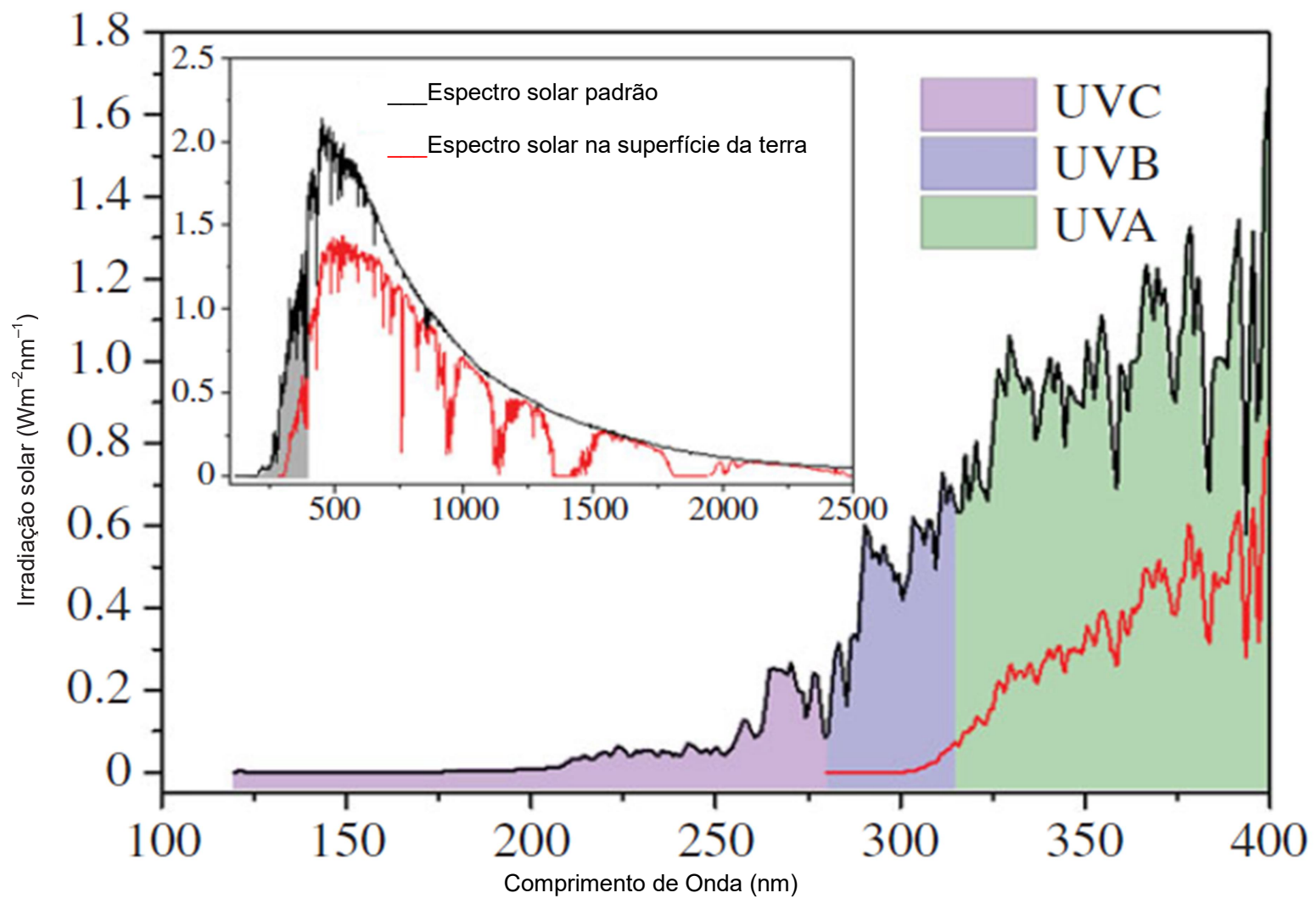

Legenda. Radiação UV dividida em UVA (verde), UVB (azul) e UVC (violeta) no espectro solar padrão, antes de atingir a superfície da Terra. A linha vermelha indica a intensidade do espectro solar após os efeitos da atmosfera. A inserção mostra o espectro solar total, com a região UV destacada em cinza.

A energia da radiação solar e o $\lambda$ são inversamente proporcionais. Os raios UV possuem menor $\lambda$, porém são os responsáveis pelas reações fotoquímicas geradas na pele. Os raios UVC não atingem a superfície da Terra, pois são bloqueados pela camada de ozônio, entretanto, os raios UVB e UVA atingem a pele em diferentes níveis de profundidade. O alcance dos raios UV na pele podem causar diversos efeitos deletérios (NASCIMENTO, SANTOS, AGUIAR, 2013; OLIVEIRA, 2015).

Os raios UVB, mais energéticos, alcançam somente a epiderme, causando eritema, inflamação e imunossupressão devido à formação de ERO's. Em função da penetração na derme, os raios UVA, com maior $\lambda$, causam o fotoenvelhecimento, formação de ERO's e de rugas, por alterarem estruturas do tecido conjuntivo. Ambos os espectros, UVA e UVB, por atuarem no DNA celular, a longo prazo, podem gerar mutações e aumento da predisposição ao câncer de pele. Entretanto, os raios UVA são os principais formadores de ERO's. A Figura 2 
ilustra os danos causados pela exposição solar à pele (BERNEBURG et al.,1999; GILBERT et al., 2013; PERES, 2015; SEITÉ et al., 2012; SVOBODOVA et al., 2006 VELASCO et al., 2007).

Figura 2. Efeitos da radiação UV na pele (SVOBODOVA et al., 2006).

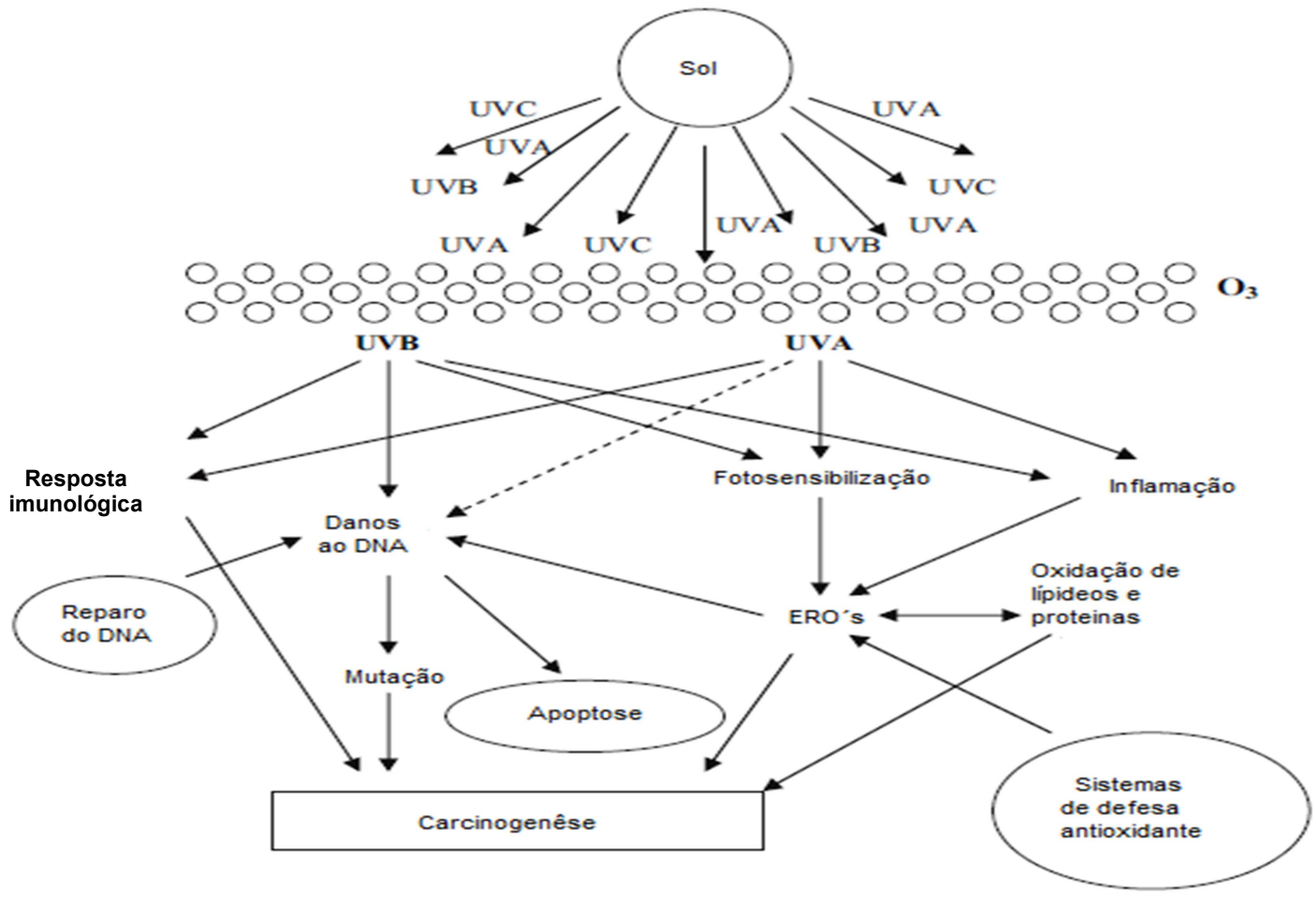

Devido à formação de ERO's, os raios UV representam ameaça ambiental à pele. A formação de ERO's, como o oxigênio singleto, radical ânion superóxido, peróxido de hidrogênio e radical hidroxil elevam o risco dos danos foto-oxidativos. As ERO's são produzidas pelo metabolismo celular sob condições fisiológicas normais. O desequilíbrio entre a formação de ERO's e os mecanismos antioxidantes do corpo desencadeia o estresse oxidativo. Na pele, as ERO's são as responsáveis pelo dano oxidativo no DNA, proteínas e lipídeos (ALONSO et al., 2009; OLIVEIRA, 2015; PERUZZI et al., 2015).

Após a exposição solar, os filtros utilizados em fotoprotetores se modificam física e quimicamente. Processos como a redistribuição vibracional intramolecular, fluorescência e fosforescência ocorrem em femtossegundos (10-15 segundos) e podem desencadear danos à pele. Entretanto, apesar dos estudos sobre as formulações fotoprotetoras visarem eficácia e compatibilidade dermatológica, existe a necessidade de compreender os fenômenos que ocorrem, 
a nível molecular, após a exposição da pele à radiação UV (RODRIGUES, STANIFORTH, STAVROS, 2017).

\subsection{Fotoproteção}

Os filtros solares absorvem, refletem ou dispersam os raios UV, sendo os protetores solares, a mistura de filtros em formulações cosméticas. Os protetores solares são a principal estratégia utilizada para a proteção frente à exposição aos raios solares (KRAUSE, et al., 2012; VELASCO et al., 2011).

Os fotoprotetores são compostos por filtros UV que agem por diferentes mecanismos. Os filtros são moléculas ou complexos moleculares categorizados como filtros orgânicos ou inorgânicos, sendo classificados, respectivamente, em filtros químicos e físicos. Os filtros orgânicos (químicos) absorvem a radiação UV. Os inorgânicos (físicos) refletem ou dispersam os raios UV, podendo, também, absorver, dependendo do tamanho da partícula (PEREIRA et al., 2015; SARRUF et al., 2013; VELASCO et al., 2007; VELASCO et al., 2011).

Os filtros solares podem exercer proteção frente à radiação UVA, filtros UVA; radiação UVB, filtros UVB; e proteção UVA/UVB filtros de amplo espectro. Os filtros UVB são efetivos e absorvem até $90 \%$ da radiação de $\lambda$ entre 290 e 320 $\mathrm{nm}$, no entanto, os filtros UVA e de amplo espectro são resultados de pesquisas mais recentes (BALOGH et al., 2011; DAMIANI, BASCHONG, GRECI, 2007).

A legislação brasileira, juntamente com o MERCOSUL, permite o uso de 38 filtros solares, que estão listados na resolução RDC $n^{\circ} 47$ de 16 de março de 2006. Entretanto, os filtros solares mais utilizados estão descritos no Quadro 1 (BRASIL, 2006; FLOR, DAVOLOS, CORREA, 2007; LOPES, CRUZ, BATISTA, 2015; PALM, O’DONOGHUE, 2007). 
Quadro 1. Principais filtros UV utilizados em fotoprotetores (LOPES, CRUZ, BATISTA, 2015).

\begin{tabular}{|c|l|c|}
\hline \hline Classe & \multicolumn{1}{|c|}{ Ingrediente } & $\begin{array}{c}\text { Faixa de Proteção } \\
\text { UV }\end{array}$ \\
\hline \hline \multirow{2}{*}{ Salicilatos } & $\begin{array}{l}\text { Salicilato de octila } \\
\text { Triazona de Etila } \\
\text { Homosalato }\end{array}$ & UVB \\
UVB \\
UVB
\end{tabular}

A radiação UVA é tão nociva quanto a radiação UVB e seu diferencial é o tempo para a ocorrência de seus efeitos danosos. A necessidade do uso de fotoprotetores de amplo espectro é uma medida de fotoproteção essencial, quer seja pela ação profilática contra o envelhecimento precoce, quer seja pela diminuição da incidência de câncer de pele (BALOGH et al., 2011; VELASCO et al., 2007).

O uso de protetores solares teve seu início por volta de 1930 e, embora tenha aumentado desde então, o melanoma também tem registrado um aumento em paralelo (KRAUSE et al., 2012; RUSZKIEWICZ et al., 2017).

Pesquisas sugerem que a incidência de câncer de pele elevou-se ao redor do mundo. Em 2020, prevê-se diagnosticar, aproximadamente, 15 milhões de novos casos mundialmente. Estimou-se que, em 2016, somente nos Estados Unidos, 144.866 novos casos de melanoma seriam diagnosticados, e destes, 76.380 invasivos. Já, no Brasil, o câncer de pele é a neoplasia de maior incidência. A carcinogênese, na pele, pode ser desencadeada por um dos principais danos causados pela exposição solar, a formação de espécies reativas com consequente degradação do DNA, proteínas e lipídeos (KRAUSE et al., 2012; MOHAN, CHANG, 2014; ROGERS et al., 2015; RUSZKIEWICZ, et al., 2017; URASAKI et al., 2016; STERN, 2010; SIEGEL, MILLER, JEMAL, 2016). 


\subsubsection{Metoxicinamato de octila}

O metoxicinamato de octila ( $\mathrm{MCO}$ ), também conhecido como etilhexil metoxicinamato, é um filtro solar UVB da classe dos cinamatos e amplamente utilizado em formulações fotoprotetoras, variando sua concentração máxima entre 7,5\% (COLIPA) e 10\% (USA). A Figura 3 ilustra a estrutura molecular do MCO (JENTZSCH et al., 2016; KRAUSE et al., 2012; LOPES, CRUZ, BATISTA, 2015; PATTANAARGSON, LIMPHONG, 2001; ZAMBON, 2011).

Figura 3. Estrutura molecular do MCO (ZAMBON, 2011)<smiles>CCCCC(CC)COC(=O)CCc1ccc(OC)cc1</smiles>

Estudos indicaram que o MCO pode ser detectado em sangue, urina e leite materno após aplicação tópica. Entretanto, o MCO é o filtro UVB mais utilizado (AXELSTAD et al., 2011; JANJUA et al., 2004; JENTZSCH et al., 2016; LOPES, CRUZ, BATISTA, 2015; SCHLUMPF et al., 2001).

\subsubsection{Octocrileno}

O octocrileno (OCT) é um filtro solar UVB, também com ação UVA reduzida, conforme Figura 4, da família dos cinamatos e está presente em vários produtos cosméticos de uso diário, sendo sua concentração máxima, permitida pela legislação ao redor do mundo, de 10\%. O OCT também é utilizado como estabilizador de outros filtros, como por exemplo, a avobenzona (BAKER, HORBURY, STAVROS, 2016; POLONINI et al., 2014). 
Figura 4. Espectro do octocrileno em UV-visível (POLONINI et al., 2014)

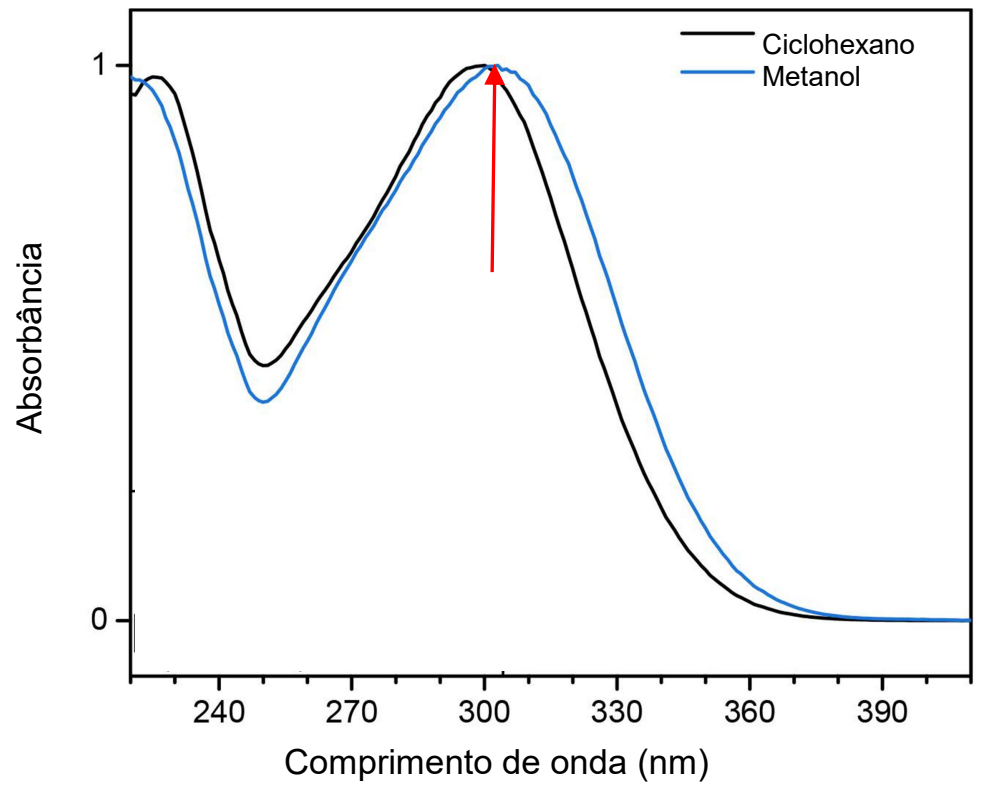

Legenda. A seta vermelha indica o pico característico do octocrileno. O perfil espectrofotométrico da figura foi obtido em dois solventes diferentes, metanol e ciclohexano. Em diferentes solventes, o pico do octocrileno destaca-se em $300 \mathrm{~nm}$.

Uma característica relevante no desenvolvimento de fotoprotetores é a solubilidade. Quanto maior o logP, maior a lipofilicidade da molécula, o OCT com $\log \mathrm{P}=6,9$, possui alta lipofilicidade devido à sua estrutura molecular, Figura 5, e esta característica apolar favorece o acúmulo e diminui sua biodegradabilidade em meios aquosos (BAKER, HORBURY, STAVROS,2016; BLÜTHGEN et al.,2014; POLONINI et al., 2014; WIJEKOON et al., 2013).

Figura 5. Estrutura molecular do octocrileno (BAKER, HORBURY, STAVROS; 2016).<smiles>CCCCC(CC)COC(=O)C(C#N)=C(c1ccccc1)c1ccccc1</smiles> 


\subsubsection{Salicilato de octila}

Os salicilatos possuem, geralmente, fraca absorção UVB, sendo o comprimento de onda máximo do salicilato de octila igual a $307 \mathrm{~nm}$, Figura 6. Entretanto, o salicilato de octila proporciona à outros ingredientes da formulação estabilidade e perfil seguro de uso (JIMÉNEZ-DÍAZ et al., 2013; LOPES, CRUZ, BATISTA, 2015; OLIVEIRA, ISAAC, 2016; RIBEIRO, 2004).

Figura 6. Estrutura geral dos salicilatos (RIBEIRO, 2004).

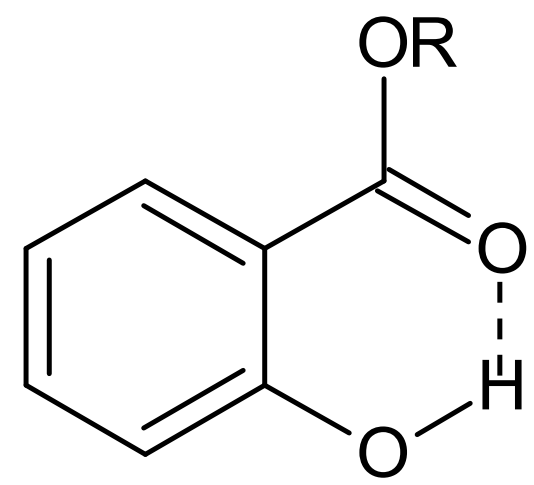

Legenda. A ligação pontilhada, na molécula geral de salicilatos, demonstra a interação intramolecular do oxigênio e do hidrogênio. Esta interação diminui a energia necessária para que os salicilatos atinjam seu estado excitatório.

\subsection{Estresse Oxidativo}

A oxidação de biomoléculas celulares por espécies reativas é um mecanismo geralmente reconhecido na patogênese de várias doenças, como por exemplo: distúrbios hepáticos, renais e pancreáticos, doenças inflamatórias reumáticas, respiratórias e cardiovasculares, além de doenças neurodegenerativas e câncer (KUNZ et al., 2008; GASCHLER, STOCKWELL, 2017; PLACHTA, BARTNIKOWSKA, OBARA, 1992).

Os mecanismos intrínsecos (metabolismo oxidativo) e extrínseco, (exposição ao ambiente) são responsáveis pela formação de espécies reativas na pele. Estes mecanismos podem desencadear a resposta inflamatória, envelhecimento precoce e redução da produção de antioxidantes. Além disso, a geração das matrizes de metaloproteinases, iniciadas a partir do desequilíbrio oxidativo, degradam proteínas de sustentação, como colágeno e elastina. Estimativas sugerem que mais de $20 \%$ da população sofre de vários distúrbios de 
pele resultantes da localização e composição alterada de lipídios e proteínas na epiderme (GHANI, 2017; LEPHART, 2016; NATARAJAN et al., 2014).

A peroxidação lipídica, uma das consequências do estresse oxidativo, gera alguns aldeídos, entre os mais estudados está o dialdeído malônico (MDA). O MDA é um marcador do dano oxidativo de lipídeos em sistemas fisiológicos. Dentre os métodos existentes para quantificar o MDA, destacam-se a cromatografia gasosa, eletroforese capilar, espectroscopia UV-visível e cromatografia líquida de alta eficiência (GHANI, 2017; LEPHART, 2016; PERES, 2015).

\subsection{Ensaio do ácido tiobarbitúrico (TBARS)}

A lesão oxidativa em várias doenças indica a necessidade na avaliação confiável da peroxidação lipídica. Entre os aldeídos produzidos durante a peroxidação lipídica, o MDA e o 4-hidroxinonenal (HNE) se destacam. O HNE possui alta atividade biológica e o MDA é produzido em niveis elevados, de modo que é comunte usado como medida do estresse oxidativo. O MDA é gerado por meio da peroxidação lipídica como produto final, primário ou secundário, de baixo peso molecular. Resumidamente, MDA e HNE se originam da peroxidação de ácidos graxos poli-insaturados (BARRERA et al., 2018).

A lipoperoxidação pode ser descrita, geralmente, como um processo no qual o oxidante, radicais livres ou espécies químicas não radicais atacam lipídios contendo ligações duplas de carbono-carbono. Este processo envolve a subtração de hidrogênio de um átomo de carbono e a inserção de oxigênio, resultando na formação de radicais peroxil e hidroperóxidos lipídicos, como ilustrado na Figura 7 (ALONSO et al., 2009; BARRERA et al., 2018; JANERO, 1990; KUNZ et al., 2008). 
Figura 7. Formação do MDA e do HNE por degradação de acido graxo poliinsaturado.

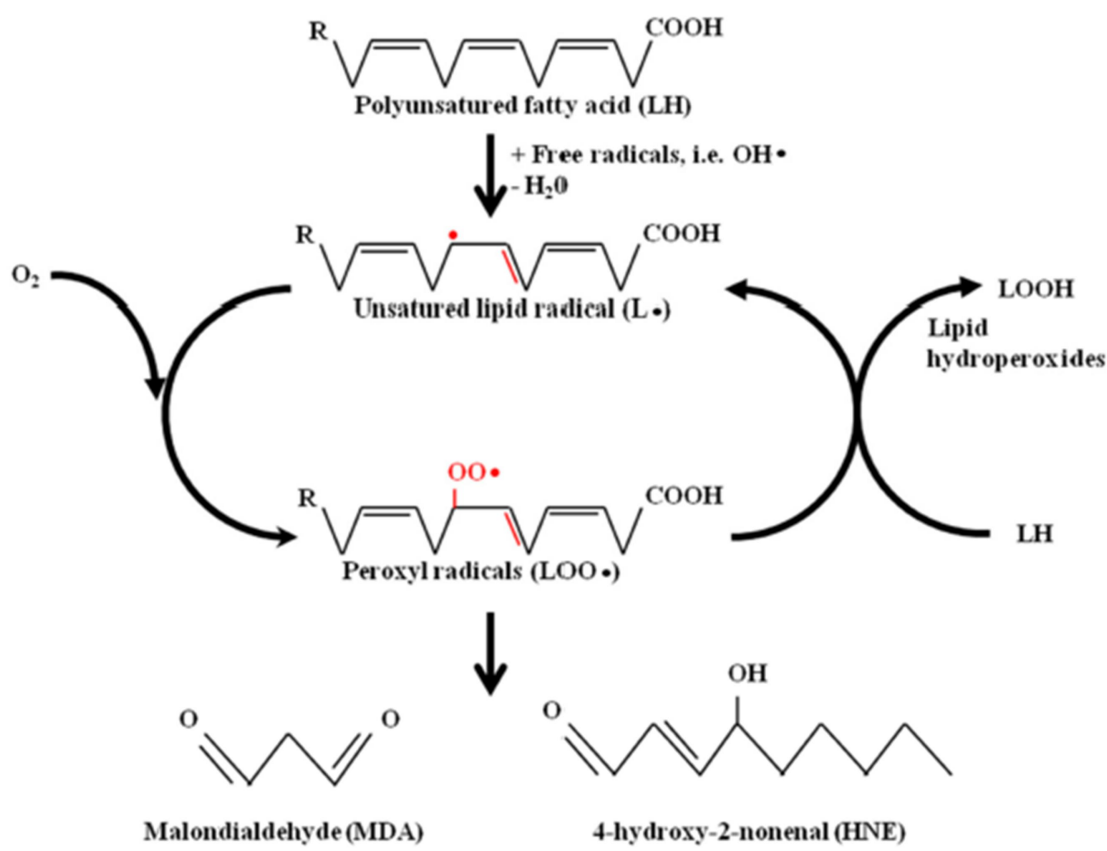

Legenda. Polyunsatured fatty acid: ácidos graxos poli-insaturados; Free radicals: radicais livres. Unsatured lipid radical: radical lipídico insaturado; Lipid hydroperoxides: Hidroperóxidos lipídicos; Peroxyl radicals: Radicais Peroxil; Malondialdehyde: Malondialdeído; 4-hydroxy-2-nonenal: 4hidroxi-2-nonenal.

Como os aldeídos têm alta reatividade química, os mamíferos desenvolveram um conjunto completo de enzimas convertendo-os em espécies químicas menos reativas e contribuindo para o controle de suas concentrações, que refletem o estado estacionário entre as taxas de formação por lipoperoxidação e catabolismo em compostos menos reativos. Uma vez formado, MDA e HNE podem ser reduzidos a álcoois por aldo-ceto redutases ou álcool desidrogenases, ou pode ser oxidado a ácidos por aldeído desidrogenases. Esta reação pode ocorrer espontaneamente ou pode ser catalisada por glutationa-stransferases. O MDA é capaz de afetar vários processos de sinalização sendo os efeitos mais deletérios a sua capacidade de ligar covalentemente a proteínas e DNA (ARGÜELLES, AYALA, MUÑOZ, 2014; BARRERA et al., 2018).

Os aldeídos derivados de lipoperoxidação, MDA e HNE, reagem facilmente com as proteínas, gerando uma variedade de adutos covalentes intermoleculares. Adutos são produtos da adição de duas ou mais moléculas diferentes, resultando em um único produto de reação contendo todos os átomos iniciais. Dependendo das características estruturais, eles podem formar bases 
Schiff (grupo funcional que contém um carbono ligado por meio de uma ligação dupla a um nitrogênio e este por sua vez a um grupo arila ou alquila, o que torna a base de Schiff uma imina estável) e / ou adutos de Michael (adição de um nucleófilo ao carbono $\beta$ de uma olefina elétron deficiente levando à formação do produto $\beta$-carbonil) com o grupo amino livre de lisina, o grupo imidazolina de histidina, o grupo guanidina da arginina e o grupo tiol da cisteína (ARGÜELLES, AYALA, MUÑOZ, 2014; BARRERA et al., 2018).

O MDA e o HNE podem formar adutos de proteína modificando especificamente os resíduos de lisil das proteínas e modificando biomoléculas, gerando neoepitopos a partir de epítopos próprios, capazes de induzir inatos indesejados e respostas imunes adaptativas, dentre as quais a aterosclerose (BARRERA et al., 2018).

Com o processo de envelhecimento, as concentrações de MDA e HNE nos eritrócitos e no plasma sanguíneo, desencadeiam ou aumentam a incidência de enfermidades, como aterosclerose, neurodegenerações, inflamações, câncer, síndrome mielodisplásica, imunossenescência, osteopenia e osteoporose. Estes adutos de aldéido a proteínas também foram detectados em tecidos cerebrais e fluidos corporais em doenças neurodegenerativas, como doença de Alzheimer, doença de Huntington, doença de Parkinson, esclerose lateral amiotrófica e síndrome de Down (ARGÜELLES, AYALA, MUÑOZ, 2014; BARRERA et al., 2018).

Os radicais hidroxil podem reagir com hidrocarbonetos formando radicais de hidrocarbonetos, e estes podem reagir novamente com oxigênio, formando radicais peróxidos ou alcóxis, desencadeando a peroxidação lipídica e a formação de subprodutos, como o MDA. Sob baixo valor de $\mathrm{pH}$ e temperatura elevada, o MDA forma adutos fluorescentes com o ácido tiobarbitúrico (TBA) na proporção de 2:1, Figura 8, sendo possível sua quantificação por meio do ensaio do ácido tiobarbitúrico (TBARS). O TBARS é um dos índices mais utilizados em ensaios clínicos no estudo do estresse oxidativo em lipídeos (ALONSO et al., 2009; BUEGE, AUST, 1978; DAMIANI, BASCHONG, GRECI, 2007; FRANTZEN et al., 2016; HONG et al., 2000; JANERO, 1990; SELJESKOG, HERVIG, MANSOOR, 2006; PESCIA et al., 2012; POPRAC et al., 2017). 
Figura 8. Reação do MDA após o processo de peroxidação lipídica (ALONSO et al., 2009).<smiles>CC(C)(C)C[14C](=O)OC(C)(C)C</smiles>

Legenda: MDA: dialdeído malônico; TBA: ácido tiobarbitúrico.

\subsection{Tape stripping}

A epiderme consiste, basicamente, em uma barreira imunológica, física e biológica, sendo o estrato córneo (EC), sua camada superficial, responsável pela proteção física (ALONSO et al., 2009; EZERSKAIA, 2017; DICKEL, 2017).

A técnica de tape stripping é um método utilizado para avaliar a função barreira, enfermidades e quantificar a penetração de moléculas na pele. O método consiste na remoção de camadas microscópicas $(0,5-1 \mu \mathrm{m})$ do $E C$, utilizando fitas adesivas aplicadas sequencialmente no EC, com pressão uniforme e velocidade constante. A pressão uniforme e a velocidade durante a aplicação e retirada das fitas são fatores básicos cruciais. A remoção e a quantidade do estrato córneo estão diretamente ligadas à pressão e velocidade exercidas durante as retiradas das fitas (DICKEL, 2017; EZERSKAIA, 2017; LADEMANN, 2009).

Há fatores intrínsecos e extrínsecos que afetam a quantidade removida de EC. Os fatores intrínsecos são parâmetros da pele, como idade, hidratação, valor de $\mathrm{pH}$ e etnia. Além disso, o sítio de remoção influenciará no número e quantidade de corneócitos e quantidade e composição dos lipídeos. Entre os fatores extrínsecos, encontram-se a quantidade de EC removido por fita, o tipo de fita, pressão de remoção e a composição do produto aplicado na pele (LADEMANN, 2009).

A região de aplicação necessita de cuidados, visando garantir a uniformidade durante a aplicação da fita. Diversas fitas são usadas na aplicação da técnica de tape stripping. A fita utilizada deve garantir uma composição uniforme e uma distribuição homogênea do adesivo, sendo que o tamanho da 
área da fita deve ser padronizado e possuir uma compatibilidade dérmica adequada. A região deve estar livre de pelos terminais, velos e áreas irregulares, como cicatrizes e músculos adjacentes. Diversas fitas são usadas na aplicação da técnica de tape stripping (ESCOBAR-CHAVEZ et al., 2008; LADEMANN, 2009).

O tape stripping, apesar das variáveis, apresenta-se como um método robusto e simples para estudos relacionados ao EC. Apesar da topografia da pele não favorecer uma remoção homogênea do $E C$, pode-se usar rolos auxiliares durante as aplicações para garantir a uniformidade. Uma forma de evitar e diminuir a influência das variáveis do método é determinar a quantidade de estrato córneo retirado em cada fita (ESCOBAR-CHAVEZ et al., 2008; LADEMANN, 2009). 


\section{OBJETIVOS}

\subsection{Objetivo geral}

O projeto de pesquisa compreendeu a avaliação ex vivo da eficácia de filtros solares UVB.

\subsection{Objetivos específicos}

O projeto de pesquisa apreciou atingir as seguintes metas:

(i) preparo de amostras em emulsão O/A contendo $p$ metoxicinamato de octila, salicilato de octila ou octocrileno isoladamente;

(ii) caracterização e eficácia funcional in vitro das preparações por espectrofotometria de refletância difusa com esfera de integração;

(iii) validação de método analítico por cromatografia à líquido de alta eficiência (CLAE) para a quantificação do MDA gerado por peroxidação lipídica;

(iv) determinação da eficácia ex vivo dos filtros solares UVB por meio do doseamento da lipoperoxidação a partir do estrato córneo obtido por tape stripping. 


\section{MATERIAL E MÉTODOS}

\subsection{Material}

Os equipamentos e aparatos utilizados na pesquisa estão relacionados no Quadro 2.

Quadro 2. Equipamentos utilizados nesta pesquisa.

\begin{tabular}{|c|c|}
\hline Equipamento & Marcas e Modelos \\
\hline Agitador mecânico & $\mathrm{IKA}^{(\mathbb{B})} \mathrm{RW} 20 \mathrm{n}$ \\
\hline Balança analítica & Shimadzu $^{\circledR}$ AUY 220 \\
\hline Balança semi-analítica & Gehaka $^{\circledR}$ BG 4000 \\
\hline Centrífuga & Hitachi $^{\circledR} \mathrm{RX2}$ \\
\hline Peagâmetro & Quimis $^{\circledast}$ Q400 AS \\
\hline Espectrofotômetro & ThermoScientific ${ }^{\circledR}$ Evolution 600 \\
\hline Banho termostatizado & Nova Ética ${ }^{\circledR}$ N480 \\
\hline Câmara de fotoestabilidade & Atlas Suntest ${ }^{\circledR}$ CPS + \\
\hline Centrífuga & Centrífuga Hitachi ${ }^{\otimes}$ RX2 \\
\hline $\begin{array}{l}\text { Espectrofotômetro de refletância } \\
\text { difusa com esfera de integração }\end{array}$ & Labsphere $^{\circledR}$ UV-2000S \\
\hline Fitas adesivas para tape stripping & $3 \mathrm{M}^{\circledR}$ Scotch MagicTM Tape \\
\hline Micropipetas monocanal & Eppendorf $^{\circledR} 100-1000 \mu \mathrm{L}$ e $1,0-10,0 \mathrm{~mL}$ \\
\hline Refrigerador & Consul ${ }^{\otimes}$ Frost Free 60 \\
\hline Sistema purificador de água & Merck Millipore ${ }^{\circledR}$ Mili- $Q^{\circledR}{ }^{\circledR}$ Simplicity UV \\
\hline Espectrofotômetro & Thermo Scientific ${ }^{\circledR}$ Evolution 600 \\
\hline Termômetro digital & JProlab $^{\circledR}$ \\
\hline Placas de polimetilmetacrilato (PMMA) & HelioScreen $^{\otimes}$ Helioplate HD 6 \\
\hline Banho de ultrassom & Unique ${ }^{\circledR}$ UltraCleaner $1600 \mathrm{~A}$ \\
\hline
\end{tabular}

\subsection{Matérias-Primas e Solventes}

As matérias-primas utilizadas na preparação das formulações fotoprotetoras possuíam grau de pureza farmacêutico ou cosmético. Os solvente utilizados possuíam grau analítico. As matérias-primas e o solvente utilizados nesta pesquisa estão relacionados no Quadro 3. 
Quadro 3. Matérias-primas e solventes utilizados na pesquisa.

\begin{tabular}{|c|c|c|}
\hline $\begin{array}{c}\text { Matéria-prima/ solvente } \\
\text { (nome comercial) }\end{array}$ & Nomenclatura INCI & $\begin{array}{l}\text { Fornecedorl } \\
\text { Fabricante }\end{array}$ \\
\hline Salicilato de octila & Ethylhexyl salicylate & Fagron \\
\hline Octocrileno & Octocrylene & Basf \\
\hline Metoxicinamato de octila & Octyl methoxycinnamate & Basf \\
\hline Trietanolamina & Triethanolamine & Volp \\
\hline Propilenoglicol & Propyleneglycol & Emfal \\
\hline EDTA dissódico & $\begin{array}{l}\text { Ethylenediaminetetraacetic } \\
\text { disodium }\end{array}$ & Fagron \\
\hline Aristoflex ${ }^{\circledR}$ AVC & $\begin{array}{l}\text { Ammoniumacryloyldimethyltaura } \\
\text { te/VP copolymer }\end{array}$ & PharmaSpecial \\
\hline Euxyl ${ }^{\circledR}$ PE 9010 & $\begin{array}{l}\text { Phenoxyethanol (and) } \\
\text { ethylhexylglycerin }\end{array}$ & Schülke Inc. \\
\hline Etanol & Ethanol & Synth \\
\hline Hidroxitolueno butilado & Butylated hydroxytoluene & $\begin{array}{l}\text { Vital } \\
\text { Especialidades }^{\circledR}\end{array}$ \\
\hline Ácido tiobarbitúrico & 2-Thiobarbituric acid & Merck \\
\hline Metanol & Methanol & Merck \\
\hline Ácido fosfórico & Phosphoric acid & Sigma Aldrich \\
\hline Cloreto de sódio & Sodium chloride & Pharma Special \\
\hline $\begin{array}{l}\text { Potássio fosfato } \\
\text { monobásico }\end{array}$ & $\begin{array}{l}\text { Potassium monobasic } \\
\text { phosphate }\end{array}$ & QM \\
\hline Cloreto de potássio & Potassium Chloride & Galena \\
\hline $\begin{array}{l}1,1,3,3 \\
\text { tetrametoxipropano }\end{array}$ & $\begin{array}{l}\text { 1,1,3,3 - tetramethoxypropane } \\
\text { (TEP) }\end{array}$ & Aldrich \\
\hline Álcool n-butílico & N-butyl alcohol & Synth \\
\hline
\end{tabular}

Legenda: Nomenclatura conforme INCI (International Nomenclature of Cosmetic Ingredients).

\subsection{Preparação das formulações}

A base para a incorporação dos filtros foi obtida utilizando o polímero Aristoflex ${ }^{\circledR}$ AVC. Partindo da base, foram preparados emusões contendo os filtros salicilato de octila, octocrileno e metoxicinamato de octila em suas respectivas 
concentrações máximas permitidas pela legislação, 5,0;10,0; e 10,0\% (p/p), respectivamente. Ademais das formulações com os filtros solares, foi preparada uma amostra contendo apenas a base, ausente dos filtros (BRASIL, 2006). A Tabela 1 apresenta as concentrações utilizadas nas formulações.

Tabela 1. Concentrações de filtros nas formulações fotoprotetoras.

\begin{tabular}{c|c|c|c}
\hline \hline \multirow{2}{*}{ Formulações } & \multicolumn{3}{|c}{ Proporção (\%p/p) } \\
\cline { 2 - 4 } & $\begin{array}{c}\text { Metoxicinamato de } \\
\text { octila }\end{array}$ & Salicilato de octila & Octocrileno \\
\hline \hline F1 & - & - & 10,0 \\
\hline F2 & 10,0 & - & - \\
\hline F3 & - & 5,0 & - \\
\hline F4 & - & - & - \\
\hline \hline
\end{tabular}

Legenda. Concentração de filtros nas formulações. (-) composto não adicionado.

A Tabela 2 apresenta as matérias-primas, classe cosmética e suas concentrações nas preparações. Os filtros foram selecionados de acordo com a segurança de uso, e os demais componentes da formulação foram adicionados visando à estabilidade das amostras.

Tabela 2. Composição qualitativa e quantitativa (\%p/p) das formulações fotoprotetoras.

\begin{tabular}{c|c|c|c|c|c}
\hline \hline \multirow{2}{*}{ Composição } & \multirow{2}{*}{ Função } & \multicolumn{4}{|c}{ Proporção (\%p/p) } \\
\cline { 3 - 6 } & & F1 & F2 & F3 & F4 \\
\hline \hline Propilenoglicol & Emoliente & 5,0 & 5,0 & 5,0 & 5,0 \\
\hline Água purificada & Veículo & 81,8 & 81,8 & 86,8 & 91,8 \\
\hline EDTA dissódico & Sequestrante & 0,2 & 0,2 & 0,2 & 0,2 \\
\hline Aristoflex ${ }^{\circledR}$ AVC & Polímero & 2,5 & 2,5 & 2,5 & 2,5 \\
\hline Octocrileno & Filtro UVB & 10,0 & - & - & - \\
\hline $\begin{array}{c}\text { Metoxicinamato de } \\
\text { octila }\end{array}$ & Filtro UVB & - & 10,0 & - & - \\
\hline Salicilato de octila & Filtro UVB & - & - & 5,0 & - \\
\hline Euxyl ${ }^{\circledR}$ PE9010 & Conservante & 0,5 & 0,5 & 0,5 & 0,5 \\
\hline Trietonolamina & Corretor de pH & q.s. & q.s. & q.s. & q.s. \\
\hline \hline
\end{tabular}

Legenda: q.s.: quantidade suficiente; (-): matéria-prima não adicionada. O INCl foi descrito no Quadro 2. 
O modo de preparo das formulações é descrito a seguir:

1) Dissolveu-se o EDTA dissódico na solução de propilenoglicol e água sob agitação. Após total homogeneização, adicionou-se o Aristoflex ${ }^{\circledR}$ AVC, sob agitação de 500 rpm até formação do gel.

2) Após a formação do gel, adicionaram-se os filtros UV, isoladamente, sob a agitação de 1000 rpm por 5 minutos. Ao final, adicionou-se o agente conservante, agitou por 2 minutos à $500 \mathrm{rpm}$ e ajustou-se o valor de pH com trietanolamina $(\mathrm{pH}=6,5 \pm 0,5)$.

As amostras foram acondicionadas em potes opacos de polietileno, capacidade de $30 \mathrm{~g}$.

\subsection{Estudo de Estabilidade Preliminar das formulações}

As formulações foram submetidas ao Estudo de Estabilidade Preliminar (EEP). O EEP evidencia possíveis sinais de instabilidade. Foram realizados ensaios de Centrifugação e Estresse Térmico, após 48 horas do preparo das formulações (BABY, 2008; BRASIL, 2004).

Para a realização do teste de centrifugação, foram pesados $10 \mathrm{~g}$ de cada amostra em tubos de centrífuga. As condições experimentais durante o teste foram: temperatura ambiente $\left(25,0 \pm 2,0{ }^{\circ} \mathrm{C}\right)$; velocidade de rotação de $3.000 \mathrm{rpm}$; e tempo de teste de 30 minutos (BABY, 2008; BRASIL, 2004).

Para a realização do estresse térmico foram pesados $5 \mathrm{~g}$ de cada formulação em tubos de ensaio. Os tubos foram submetidos ao banho termostatizado elevando-se a temperatura gradativamente, por períodos controlados, a partir do valor inicial. A temperatura inicial foi de $40^{\circ} \mathrm{C}$ e a temperatura final de $80^{\circ} \mathrm{C}$. A cada 30 minutos a temperatura era elevada $10^{\circ} \mathrm{C}$ (BABY, 2008; BRASIL, 2004).

Após repouso das formulações, por um período de 60 minutos, foram avaliadas possíveis alterações visuais, como separação de fases, coalescência ou presença de precipitados. As formulações foram classificadas como normais (N) ou modificadas (M) e aprovadas em caso de classificação $\mathrm{N}$ em ambos testes (BRASIL, 2004, BRASIL, 2012a). 


\subsection{Determinação do valor pH e das características} organolépticas das formulações

O valor de $\mathrm{pH}$ das formulações foi ajustado $(6,5 \pm 0,5)$ com trietanolamina, visando meio compatível com a epiderme. $\mathrm{O}$ valor do $\mathrm{pH}$ foi determinado em peagâmetro pela imersão direta do eletrodo no sistema emulsionado à temperatura ambiente $\left(25,0 \pm 2,0^{\circ} \mathrm{C}\right)$. As características organolépticas (cor, odor e aspecto) também foram determinadas.

\subsection{Caracterização funcional in vitro}

A eficácia da atividade fotoprotetora in vitro, fator de proteção solar (FPS), foi determinada por espectrofotometria de refletância difusa com esfera de integração (Labsphere ${ }^{\circledR}$ UV 2000 S Ultraviolet Transmittance Analyzer). Os valores espectrofotométricos foram gerados a partir da aplicação das amostras, em forma de filme $\left(1,3 \mathrm{mg} / \mathrm{cm}^{2}\right)$, sobre o substrato que mimetiza a rugosidade da pele humana (placas de $25 \mathrm{~cm}^{2}$ de PMMA) e submetidas, após intervalo de 20 minutos, à leitura espectrofotométrica compreendendo o intervalo de comprimento de onda $(\lambda, \mathrm{nm})$ entre 290 e $400 \mathrm{~nm}$ e registros a cada 1,0 nm. Foi empregado como branco uma placa de PMMA sem as amostras (BRASIL, 2012c; CHOQUENET et al., 2009; OLIVEIRA et al., 2015; SPRINGSTEEN et al., 1999; VELASCO et al., 2008).

O programa de análise, UV $2000^{\circledR}$, registrou os valores espectrofotométricos e converteu em valores de FPS estimado (Equação 1). Foram utilizadas réplicas de três e, no mínimo, cinco registros de transmitância para cada amostra (COLIPA, 2006; U.S., 2015; SPRINGSTEEN et al., 1999).

$$
F P S=\frac{\int_{280 \mathrm{~nm}}^{400 \mathrm{~nm}} E_{\lambda} S_{\lambda} d \lambda}{\int_{280 \mathrm{~nm}}^{400 \mathrm{~nm}} E_{\lambda} S_{\lambda} T_{\lambda} d \lambda}
$$

Equação 1. Fator de Proteção Solar in vitro (FPS estimado).

Legenda. $\mathrm{E}_{\lambda}=$ eficácia eritematógena espectral da $\mathrm{CIE}$ (Commission Internationale de l'Eclairage); $\mathrm{S}_{\lambda}=$ irradiância solar espectral; $\mathrm{T}_{\lambda}=$ transmitância espectral da amostra; $\mathrm{d} \lambda=$ intervalo dos comprimentos de onda.

O comprimento de onda crítico estimado é calculado pelo software, conforme Equação 2. 


$$
\int_{290}^{\lambda c} A(\lambda) d \lambda=0.9 \int_{290}^{400} A(\lambda) d \lambda
$$

Equação 2. Comprimento de onda crítico in vitro.

Legenda. $A(\lambda)=$ absorbância espectral da amostra; $d(\lambda)=$ intervalo dos comprimentos de onda.

O ensaio para determinação da fotoestabilidade dos filtros utilizou condições analíticas e substratos idênticos aos empregados nas análises de FPS, com a etapa adicional de 1 hora de irradiação em câmara de fotoestabilidade (Atlas Suntest ${ }^{\circledR}$ CPS+) (COLIPA, 2006; U.S., 2015).

A irradiância mantida foi de $580,08 \mathrm{~W} / \mathrm{m}^{2}(300-800 \mathrm{~nm})$, correspondente a irradiância no UV de $55 \mathrm{~W} / \mathrm{m}^{2}$ (Dose $=198 \mathrm{~kJ} / \mathrm{m}^{2}$ ). Os parâmetros FPS e comprimento de onda crítico foram analisados e comparados, pré-irradiação e pós-irradiação. Foram utilizadas réplicas de três e, no mínimo, cinco registros de transmitância para cada amostra.

\subsection{Espécies reativas do ácido tiobarbitúrico}

Os peróxidos lipídicos foram quantificados pelo ensaio de ácido tiobarbitúrico (TBA) com algumas modificações, por cromatografia à líquido de alta eficiência (CLAE).

\subsubsection{Preparação da solução estoque de MDA}

A solução estoque de MDA foi preparada por meio da adição de $22 \mu \mathrm{L}$ de 1,1,3,3 - tetrametoxypropane em $10 \mathrm{~mL}$ de solução a 1,0\% de ácido sulfúrico $\left(\mathrm{H}_{2} \mathrm{SO}_{4}\right)$. Após período de duas horas, tempo necessário para a hidrólise ácida, adicionaram-se $17 \mu \mathrm{L}$ desta solução e completou-se com $5 \mathrm{~mL}$ de 1,0\% de ácido sulfúrico $\left(\mathrm{H}_{2} \mathrm{SO}_{4}\right)$ em balão volumétrico. A concentração da solução estoque foi determinada por meio da leitura da absorbância por espectrofotômetro UV $\left(245 \mathrm{~nm}=13700 \mathrm{M}^{-1} \mathrm{~cm}^{-1}\right)$, sendo o branco $\mathrm{O} \mathrm{H}_{2} \mathrm{SO}_{4}$ a $1,0 \%$ (ALONSO et al., 2009). 


\subsubsection{Método analítico para a quantificação do aduto dialdeído malônico - ácido tiobarbitúrico (MDA-TBA)}

\subsubsection{Curva analítica e linearidade}

O sistema CLAE Shimadzu ${ }^{\circledR}$ Prominence composto por detector espectrofotométrico de arranjo de diodos modelo SPD-M20A e forno de colunas modelo CTO-20A foi utilizado para a quantificação $(\mu \mathrm{g} / \mathrm{mL})$ dos adutos de MDATBA. Os dados obtidos foram analisados pelo programa LC-Solution ${ }^{\circledR}$ Multi-PDA. A fase móvel foi constituída por solução de metanol e tampão de fosfato potássico $(35: 65, \mathrm{v} / \mathrm{v}$ em $\mathrm{pH} 7,0)$ e vazão de $1,0 \mathrm{~mL} / \mathrm{min}$. Utilizou-se a coluna de fase reversa C-18 $\left(4,6 \mathrm{~mm} \times 25,0 \mathrm{~cm}\right.$, Shimadzu $\left.{ }^{\circledR}\right)$. A detecção foi obtida em $532 \mathrm{~nm}$, à temperatura de $30,0 \pm 1,0^{\circ} \mathrm{C}$. A linearidade do método foi avaliada por meio da curva analítica com diferentes concentrações de MDA $(0,075 ; 0,25 ; 0,5 ; 1,0 ; 1,5$; 2,0 M) (BRASIL, 2003; BASTOS et al., 2012; OLIVEIRA, 2015; U.S., 2015; U.S., 2003; U.S. 2006).

Partindo-se da concentração encontrada da solução estoque, foram obtidas as concentrações de interesse para a realização da curva analítica. As concentrações das soluções da curva analítica foram de 0,$075 ; 0,25 ; 0,5 ; 1,0 ; 1,5$; 2,0 $\mu \mathrm{M}$, sendo o branco, metanol. Foram adicionados $144 \mu \mathrm{L}$ de $0,2 \%$ de BHT e $400 \mu \mathrm{L}$ de $\mathrm{H}_{3} \mathrm{PO}_{4}$ 0,44 $\mathrm{M}$ em tubos contendo $1 \mathrm{~mL}$ das soluções. Após agitação em vórtex, os tubos repousaram à temperatura ambiente por 10 minutos e, posteriormente, adicionados de $600 \mu \mathrm{L}$ de solução contendo 0,6\% TBA em $\mathrm{H}_{3} \mathrm{PO}_{4}$ $(0,44 \mathrm{M})$. Após adição de $0,6 \%$ de TBA os tubos ficaram em banho-maria por 45 minutos a $90^{\circ} \mathrm{C}$. Posterior ao período de incubação, os tubos foram resfriados à temperatura ambiente e a extração foi realizada por $600 \mu \mathrm{L}$ de $\mathrm{n}$-butanol seguidos de centrifugação de 3000 g por 10 minutos. Um volume de $40 \mu \mathrm{L}$ da camada de $\mathrm{n}$ butanol foi filtrado em membrana de 0,45 $\mu \mathrm{m}$ e injetado no sistema CLAE. Durante todas as etapas, as reações foram protegidas da luz ambiente. A curva foi construída a partir da média das absorbâncias em função da concentração de MDA (BASTOS et al., 2012; BRASIL, 2003).

\subsubsection{Especificidade e pesquisa de interferentes}

A especificidade é definida como a capacidade do método de medir e diferenciar o analito de componentes que possam estar presentes na amostra, 
tais como metabólitos, impurezas, compostos de degradação ou componentes da matriz (pele) (BRASIL, 2003).

Os possíveis interferentes foram analisados partindo de amostras em branco, sem estrato córneo, e amostras com alíquotas de 2,0 mg de cada uma das formulações. Além das amostras, todos os solventes foram analisados individualmente.

Vinte fitas irradiadas e não irradiadas, de cada amostra, foram adicionadas em um béquer de $250 \mathrm{~mL}$ com $10 \mathrm{~mL}$ de metanol. Os béqueres foram fechados com filme plástico e colocados no ultrassom por 15 minutos.

Uma alíquota de $1 \mathrm{~mL}$ das amostras (irradiadas e não irradiadas) foram colocadas em um tubo de vidro com tampa e foram adicionados $144 \mu \mathrm{L}$ de $0,2 \%$ de $\mathrm{BHT}$ e $400 \mu \mathrm{L}$ de $\mathrm{H}_{3} \mathrm{PO}_{4}$ 0,44M. Após agitação em vórtex, os tubos repousaram à temperatura ambiente por 10 minutos e, posteriormente, foram adicionados de $600 \mu \mathrm{L}$ de solução contendo 0,6\% TBA em $\mathrm{H}_{3} \mathrm{PO}_{4}(0,44 \mathrm{M})$. Após esta adição, os tubos ficaram em banho-maria por 45 minutos a $90^{\circ} \mathrm{C}$. Após incubação, os tubos foram resfriados à temperatura ambiente e foi adicionado 600 $\mu \mathrm{L}$ de $\mathrm{n}$-butanol seguido de centrifugação de $3000 \mathrm{~g}$ por 10 minutos. Um volume de $40 \mu \mathrm{L}$ da camada de n-butanol foi filtrado em membrana de 0,45 $\mu \mathrm{m}$ e injetado no sistema CLAE.

Todos os solventes foram filtrados em membrana de $0,22 \mu \mathrm{m}$ e foram inseridos individualmente em frascos utilizando as mesmas condições do ensaio de TBARS no sistema CLAE.

Os cromatogramas foram analisados para verificação do desempenho do método perante comparação visual dos espectros de absorção de amostras e do padrão.

\subsubsection{Precisão}

Precisão é a avaliação da proximidade dos resultados obtidos em uma série de medidas. Dois níveis de precisão foram considerados, a repetibilidade, concordância entre os resultados dentro de um curto período de tempo, com o mesmo analista e mesma instrumentação e a precisão intermediária, concordância entre os resultados obtidos em dias distintos de análise. Os valores de concentração de adutos de TBA-MDA utilizados para o cálculo foram 0,025 , 0,05 e $0,075 \mu \mathrm{M}$. 
A precisão foi calculada como desvio padrão relativo (DPR, \%), em réplicas de três, para cada valor de concentração, segundo Equação 3 (BRASIL, 2003; USA, 2005):

$$
\operatorname{DPR}(\%)=\frac{\mathrm{DP}}{\mathrm{C}} \times 100
$$

Equação 3. Precisão, calculada como desvio padrão relativo (DPR, \%).

Legenda. DP é desvio padrão e $C$ é a média das concentrações.

O critério de aceitação, utilizado para precisão, foi o DPR (\%) = $30 \%$ de acordo com a concentração da Tabela 3 American Association of Official Analytical Chemists (AOAC, 2016; CHANDRAN, SINGH, 2007).

Tabela 3. Precisão esperada em função da concentração do analito na amostra

\begin{tabular}{c|c|c|c}
\hline \hline \% Analito & Fração da massa & Unidade & DPR (\%) \\
\hline 0,00001 & $10^{-7}$ & $100 \mathrm{ppb}(\mu \mathrm{g} / \mathrm{kg})$ & 15 \\
\hline 0,000001 & $10^{-8}$ & $10 \mathrm{ppb}(\mu \mathrm{g} / \mathrm{kg})$ & 21 \\
\hline 0,0000001 & $10^{-9}$ & $1 \mathrm{ppb}(\mu \mathrm{g} / \mathrm{kg})$ & 30 \\
\hline \hline
\end{tabular}

Legenda. Tabela retirada do Guia de padronização de métodos AOAC.

\subsubsection{Exatidão}

A proximidade dos resultados obtidos pelo método em estudo em relação ao valor verdadeiro é representada pelo método analítico da exatidão (BRASIL, 2003; USA, 2005). A exatidão (\%) foi realizada em réplicas de três, envolvendo ensaios intra-dias (Equação 4).

$$
\text { EXATIDÃO }(\%)=\frac{C}{C T} \times 100
$$

Equação 4. Exatidão (\%).

Legenda. C é a média das concentrações e CT é a concentração teórica.

A exatidão foi calculada de acordo com a média da taxa de recuperação, em porcentagem (\%). O critério utilizado na exatidão foi de acordo com a concentração do analito na amostra, conforme Tabela 4 (AOAC, 2016). 
Tabela 4. Recuperação esperada em função da concentração do analito na amostra

\begin{tabular}{c|c|c|c}
\hline \% Analito & Fração da massa & Unidade & Recuperação (\%) \\
\hline 0,001 & $10^{-5}$ & $10 \mathrm{ppm}(\mathrm{mg} / \mathrm{kg})$ & \multirow{2}{*}{$80-100$} \\
\hline 0,0001 & $10^{-6}$ & $1 \mathrm{ppm}(\mathrm{mg} / \mathrm{kg})$ & \multirow{2}{*}{$60-115$} \\
\hline 0,00001 & $10^{-7}$ & $100 \mathrm{ppb}(\mu \mathrm{gg} / \mathrm{kg})$ & $40-120$ \\
\hline 0,000001 & $10^{-8}$ & $10 \mathrm{ppb}(\mu \mathrm{g} / \mathrm{kg})$ & $1 \mathrm{ppb}(\mu \mathrm{g} / \mathrm{kg})$ \\
\hline 0,0000001 & $10^{-9}$ & & \\
\hline \hline
\end{tabular}

Legenda. Tabela retirada do Guia de padronização de métodos AOAC.

\subsection{Ensaio ex vivo - Aspectos legais e éticos}

O projeto foi submetido ao Comitê de Ética em Pesquisa (CEP) da Faculdade de Ciências Farmacêuticas da Universidade de São Paulo, em função da realização dos ensaios ex vivo com voluntários. Os ensaios foram realizados em acordo com a Legislação Brasileira vigente, após a obtenção da aprovação do CEP, regulamentado pelo Conselho Nacional de Ética em Pesquisa, número do parecer, 1.996.575 (CONEP) (BRASIL, 2012b).

Os participantes desta pesquisa receberam as informações e esclarecimentos necessários. O consentimento de cada participante deu-se por meio da assinatura do Termo de Consentimento Livre e Esclarecido (TCLE).

Prévio ao ensaio, 9 (nove) voluntários, foram entrevistados e avaliados considerando os critérios de inclusão e exclusão exigidos pela legislação vigente. A não-inclusão ocorreu caso o sujeito se encontrasse em terapia medicamentosa tópica ou sistêmica que apresentasse possibilidade de ocasionar alterações fisiológicas após exposição solar; casos relatados de sensibilidade a produtos de uso tópico e reações inesperadas em resposta à luz. Além de que, após a avaliação clínica, há exclusão se for identificado a presença de eritema ou queimadura solar, bronzeamento, cicatrizes, lesões cutâneas e distribuição melânica irregular na área de aplicação das amostras (BRASIL, 2012b, PERES, 2015). 
Adicionalmente aos critérios impostos por legislação, foi considerado como critério de inclusão o fototipo de pele entre I e III, Quadro 4, de acordo com a escala de Fitzpatrick (BRASIL, 2012b; FITZPATRICK, 1988; SAMBANDAN, RATNER, 2011).

Quadro 4. Fototipos de pele segundo Fitzpatrick (FITZPATRICK, 1988).

\begin{tabular}{|c|c|c|c|}
\hline \hline Coloração & Tipo & Queimadura & Bronzeamento \\
\hline \hline Branca & I & Sim & Não \\
\hline Branca & II & Sim & Mínimo \\
\hline Branca & III & Sim & Sim \\
\hline Branca/Morena clara & IV & Não & Sim \\
\hline Morena & V & Não & Sim \\
\hline Escura & VI & Não & Sim \\
\hline \hline
\end{tabular}

\subsection{Técnica de tape stripping}

A técnica de tape stripping consiste na aplicação de uma formulação em área da pele previamente demarcada, distribuição homogênea da amostra, aplicação de fita adesiva e pressão sob a área e retirada da camada córnea da epiderme através da retirada da fita (PERES, 2015).

O antebraço foi limpo com compressa cirúrgica de gaze hidrófila, dobrada até a dimensão de $4 \times 3 \mathrm{~cm}$, umedecida em água destilada. As marcações foram realizadas nas dimensões de $2 \times 5 \mathrm{~cm}$ com intervalos de $1 \mathrm{~cm}$ entre amostras e de $2,5 \mathrm{~cm}$ a partir do pulso e cotovelo. Após a limpeza e demarcação, houve a aplicação das amostras. Os sete pontos amostrais foram esquematizados conforme a Figura 9, variando os locais de aplicação. 
Figura 9. Área de demarcação das fitas nos antebraços.
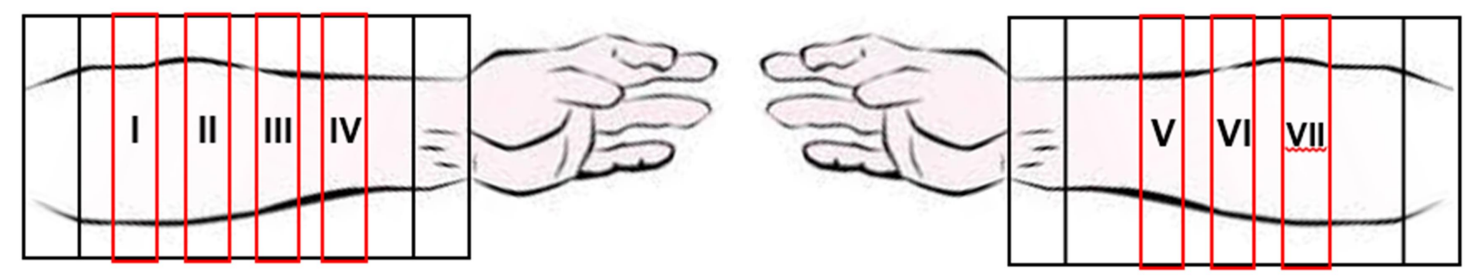

Legenda. Representação ilustrativa das regiões demarcadas nos antebraços. A sequência em algarismos romanos representa os pontos amostrais.

Foram aplicadas alíquotas de $2,0 \mathrm{mg} / \mathrm{cm}^{2}$, totalizando $20 \mathrm{mg}$ em cada área, previamente delimitadas em $10 \mathrm{~cm}^{2}(2 \times 5 \mathrm{~cm})$ na pele (Figura 10). Após a aplicação das amostras, os voluntários permaneceram em ambiente com temperatura de $21^{\circ} \mathrm{C}$.

Figura 10. representação das áreas de demarcação e aplicação no voluntário.

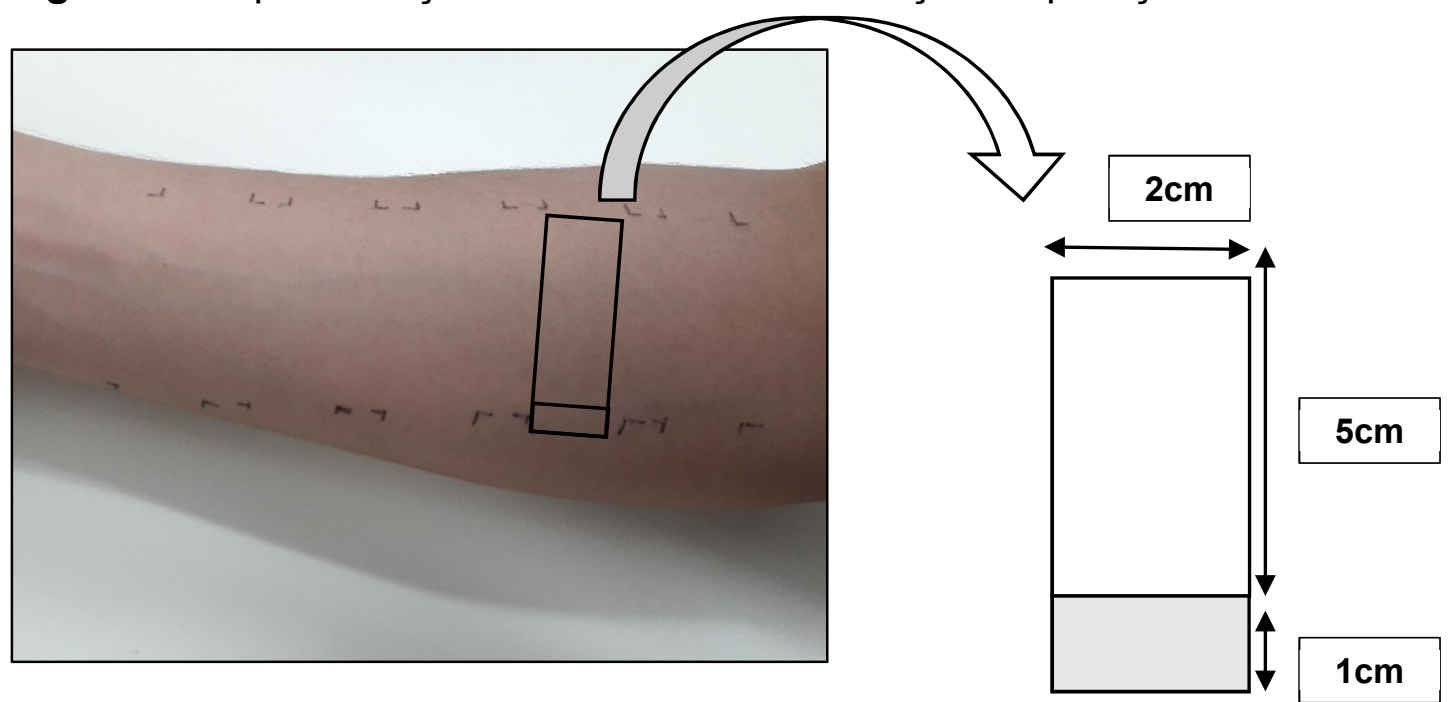

Legenda. Braço direito previamente demarcado antes da aplicação, identificação e retiradas das amostras pelo método de tape stripping. Na ampliação há o dimensionamento das fitas. A parte em cinza representa a área segura de contato para aplicação e retirada da fita.

\subsection{Preparação das amostras}

Duas horas após a última aplicação no antebraço, foi efetuada a técnica de tape stripping para remoção do estrato córneo do antebraço dos voluntários.

Para obtenção do estrato córneo irradiado, as placas com as fitas removidas foram submetidas a radiação UV em câmara de fotoestabilidade equipada com lâmpada de xenônio e filtro de vidro responsável por mimetizar a 
radiação UV, permitindo a passagem apenas de comprimentos de onda acima de $290 \mathrm{~nm}$ (ALONSO et al., 2009).

As amostras irradiadas e não irradiadas foram transferidas para béquer de $250 \mathrm{~mL}$. Os béqueres foram fechados com filme plástico contendo $10 \mathrm{~mL}$ de solvente extrator e colocados no ultrassom por 15 minutos. Em tubos de vidro com tampa, foram adicionados $1 \mathrm{~mL}$ da solução do béquer e $144 \mu \mathrm{L}$ de $0,2 \%$ de BHT e $400 \mu \mathrm{L}$ de $\mathrm{H}_{3} \mathrm{PO}_{4}$ 0,44M.

Após agitação em vórtex, os tubos repousaram à temperatura ambiente por 10 minutos e, posteriormente, adicionou-se $600 \mu \mathrm{L}$ de solução contendo $0,6 \%$ TBA em $\mathrm{H}_{3} \mathrm{PO}_{4}(0,44 \mathrm{M})$. Após adição de $0,6 \%$ de TBA, os tubos ficaram em banho-maria por 45 minutos a $90^{\circ} \mathrm{C}$. Posterior ao período de incubação, os tubos foram resfriados à temperatura ambiente e a extração foi realizada por $600 \mu \mathrm{L}$ de n-butanol seguidos de centrifugação de $3000 \mathrm{~g}$ por 10 minutos. Um volume de 40 $\mu \mathrm{L}$ da camada de $\mathrm{n}$-butanol foi filtrado em membrana de $0,45 \mu \mathrm{m}$ e colocados em vials âmbar com insert. Desde a retirada da amostra do béquer até 0 preenchimento dos vials, todas as etapas foram protegidas da luz.

\subsection{Analise dos resultados}

Com o intuito de determinar diferenças intra e entre grupos, os resultados foram analisados estatíticamente por meio do teste de análise de variância (ANOVA) seguido do teste de Tukey. A comparação foi realizada utilizando-se o Teste $t$ para duas médias. O programa utilizado foi o MiniTab ${ }^{\circledR}$ versão 18. 


\section{RESULTADOS E DISCUSSÃO}

\subsection{Preparação das formulações fotoprotetoras}

A emulsão foi obtida a partir da adição dos filtros no gel do polímero emulsificante. Sendo os filtros no estado líquido em temperatura ambiente, o processo foi realizado sem a necessidade de aquecimento. Na formulação F4 não houve adição de filtros UVB.

A quantidade de energia, neste caso a temperatura no processo de emulsão, está relacionada ao tempo de estabilidade das emulsões. Sistemas emulsionados gerados com menor energia possuem maior tempo de vida útil (SCHULTZ, et al., 2004).

A obtenção de formulações macroscopicamente estáveis baseou-se nas interações entre os filtros incorporados isoladamente (octocrileno, salicilato de octila e metoxicinamato de octila) na base polimérica.

5.2. Estudo de Estabilidade Preliminar das formulações fotoprotetoras

A verificação da estabilidade foi realizada por meio dos testes de centrifugação e estresse térmico. A finalidade destes é acelerar possíveis mecanismos de instabilidade inerente aos sistemas emulsionados. Os resultados de ambos testes estão descritos na Tabela 5.

Tabela 5. Testes de centrifugação e estresse térmico aplicado as formulações fotoprotetoras.

\begin{tabular}{c|c|c}
\hline \hline \multirow{2}{*}{ Formulações } & \multicolumn{2}{|c}{ Estudo de Estabilidade Preliminar } \\
\cline { 2 - 3 } & Centrifugação & Estresse Térmico \\
\hline \hline F1 & $\mathrm{N}$ & $\mathrm{N}$ \\
\hline F2 & $\mathrm{N}$ & $\mathrm{N}$ \\
\hline F3 & $\mathrm{N}$ & $\mathrm{N}$ \\
\hline F4 & $\mathrm{N}$ & $\mathrm{N}$ \\
\hline \hline
\end{tabular}

Legenda. N: Normal; F1: Octocrileno; F2: Metoxicinamato de octila; F3: Salicilato de octila; F4: Base sem filtros. 
As emulsões estão sujeitas a coalescência, amadurecimento ou maturação de Ostwald (Ostwald ripening) e inversão de fases, ademais dos processos de floculação e cremeação. A coalescência pode ser vista a olho nu devido à separação de fases impulsionada pela distribuição do tamanho das gotículas da emulsão, já, a maturação de Ostwald, é caracterizada pela dissolução de gotículas menores formando gotículas maiores que desestabilizam o sistema emulsionado. Quando as gotículas formam aglomerados reversíveis na emulsão, caracteriza-se a floculação, sendo a cremeação a dispersão das fases devido à diferença de densidade (GALVÃO, 2015; PERES, 2017; PERES, 2015).

Nas formulações, devido à compatibilidade dos filtros na base polimérica e a estabilidade proporcionada pela concentração do polímero, não ocorreram alterações visíveis na estabilidade das amostras (CLARIANT, 2013). Conforme a Tabela 5, as formulações não apresentaram alterações após o estudo da estabilidade preliminar, sendo, portanto aprovadas.

\subsection{Determinação do valor de $\mathrm{pH}$ e das características} organolépticas das formulações

A separação de dispersões óleo/água é um processo complexo sob ponto de vista físico-químico. Majoritariamente dominado pelos mecanismos de coalescência e colisão de gotículas, o processo de separação de fases ainda é um desafio a ser completamente elucidado. O processo de coalescência envolve ampla escala de tempo e estabilidade do sistema (BREMOND, THIAM, BIBETTE, 2008; FIROOZ et al, 2016; FRISING, NOÏK, DALMAZZONE, 2006).

As formulações foram analisadas visualmente, $48 \mathrm{~h}$ após o preparo quanto ao aspecto, cor e odor. O tempo de $48 \mathrm{~h}$ de repouso faz-se necessário devido à necessidade da finalização e estabilidade do processo de emulsificação. Ademais, foi mensurado o valor de $\mathrm{pH}$ das amostras (BABY, 2007; BRASIL, 2004). A Tabela 6 descreve os resultados obtidos. 
Tabela 6. Características organolépticas e físico-químicas das formulações fotoprotetoras.

\begin{tabular}{c|l|c}
\hline \hline Formulações & \multicolumn{1}{|c|}{ Aspecto } & Valor de pH \\
\hline $\mathbf{F 1}$ & $\begin{array}{l}\text { Emulsão homogênea, de coloração } \\
\text { branca e odor caracteristico }\end{array}$ & $6,1 \pm 0,05$ \\
\hline $\mathbf{F 2}$ & $\begin{array}{l}\text { Emulsão homogênea, de coloração } \\
\text { branca e odor caracteristico }\end{array}$ & $6,2 \pm 0,08$ \\
\hline $\mathbf{F 3}$ & $\begin{array}{l}\text { Emulsão homogênea, de coloração } \\
\text { branca e odor caracteristico }\end{array}$ & $6,2 \pm 0,08$ \\
\hline $\mathbf{F 4}$ & $\begin{array}{l}\text { Base polimérica transparente e odor } \\
\text { característico }\end{array}$ & $6,7 \pm 0,16$ \\
\hline \hline
\end{tabular}

Legenda. N: Normal. F1: Octocrileno; F2: Metoxicinamato de octila; F3: Salicilato de octila; F4: Base sem filtros. Valores de $\mathrm{pH}$ foram realizados em triplicata e acompanhados do desvio padrão.

O aspecto das formulações fotoprotetoras foi considerado adequado. Não houve alterações que indicassem instabilidade e o odor foi característico, de acordo com o filtro empregado na base. A variação do valor de $\mathrm{pH}$ das formulações ocorreu devido aos ajustes que foram realizados durante a técnica de preparo. O polímero, utilizado nas preparações, apresenta-se estável no intervalo de valor de $\mathrm{pH}$ de 4,0 a 9,0 e nas concentrações de 0,5 a 5,0\%; foi utilizado a concentração de 2,5\% nas formulações (BRASIL, 2004; CLARIANT, 2013).

$\mathrm{Na}$ pele, o valor de $\mathrm{pH}$ contribui para a função barreira, homeostase e adesão das células no estrato córneo, ademais de atividade antimicrobiana. Formulações direcionadas à utilização na epiderme, sem a intenção de ultrapassar a barreira cutânea, necessitam de valores de pH que não interfiram na sua fisiologia. Os valores de $\mathrm{pH}$, ajustados nas formulações, apresentaram-se compatíveis para a estabilidade e aplicação na epiderme. Portanto, os parâmetros analisados estavam de acordo com a manutenção da biocompatibilidade da pele (FIROOZ, 2016; JANG, 2016; SARRUF, 2013).

\subsection{Eficácia fotoprotetora in vitro}

A determinação da eficácia fotoprotetora in vitro foi realizada por meio de espectrofotometria de refletância difusa com esfera de integração. Os dados 
foram tratados pelo programa acoplado ao equipamento $\left(U V^{\circledR} 2000\right)$. $O U^{\circledR} 2000$ converteu os valores de transmitância em resultados estimados de FPS e comprimento de onda crítico $(\mathrm{nm})$ das formulações.

Todos os filtros (F1: Octocrileno; F2: Metoxicinamato de octila; F3: Salicilato de octila) utilizados nas formulações possuem apenas proteção UVB (290-320 nm). A radiação UVB, segundo Filip e colaboradores (2011), é a responsável pelos maiores danos nas células, devido aos anéis aromáticos do DNA, como as purinas. A formação de dímeros de timina, gerados devido à fotodegradação do DNA, são os principais responsáveis por desencadear o processo de mutagênese. A radiação UVB também é responsável por desencadear a peroxidação lipídica na pele. O FPS e o comprimento de onda crítico de F1, F2 e F3 foram obtidos in vitro e estão descritos na Tabela 7 (BRIASCO et al., 2017; FILIP et al., 2011; ZEGARSKA et al., 2017).

Tabela 7. Valores de FPS e comprimento de onda crítico in vitro das formulações fotoprotetoras.

\begin{tabular}{c|c|c|c|c}
\hline \multirow{2}{*}{ Formulações } & \multicolumn{2}{|c|}{$\begin{array}{c}\text { Fator de Proteção Estimado } \\
\text { (FPS) }\end{array}$} & \multicolumn{2}{|l}{ Comprimento de onda crítico (nm) } \\
\cline { 2 - 5 } & Pré-Irradiação & Pós-irradiação & Pré-Irradiação & Pós-irradiação \\
\hline F1 & $6,7 \pm 2,1^{a}$ & $5,7 \pm 2,1^{a}$ & $360,3 \pm 3,8^{b}$ & $358,0 \pm 3,5^{b}$ \\
\hline F2 & $8,0 \pm 3,6^{b}$ & $4,7 \pm 1,5^{c}$ & $343,3 \pm 3,4^{a}$ & $340,7 \pm 1,6^{d}$ \\
\hline F3 & $1,9 \pm 0,2^{c}$ & $1,0 \pm 0,0^{b}$ & $347,7 \pm 8,1^{d}$ & $334,3 \pm 6,6^{a}$ \\
\hline F4 & & & N.A. & \\
\hline \hline
\end{tabular}

Legenda: N.A: Não aplica; F1: Octocrileno; F2: Metoxicinamato de octila; F3: Salicilato de octila; F4: Base sem filtros. Valores de comprimento de onda e FPS foram realizados em triplicata. Os resultados pré e pós irradiação foram avaliados de acordo com o teste $t$-student pareado para comparação entre as médias (nível de significância $=0,05$ ). Letras diferentes na mesma coluna indicam diferença estatística significativa entre os resultados. 
Foi realizado o teste $t$-student para as médias antes e após irradiação, tanto para o FPS quanto para o comprimento de onda crítico. Houve diferenças significativas entre as amostras F2 e F3, antes e após irradiação, porém, não houve diferenças na amostra F1.

A amostra F2 possui um filtro UVB que reduz a sua capacidade de proteção frente aos raios UV quando exposto à luz. Em filtros solares contendo grupamentos na posição para-substituídos, como ilustrado na Figura 3, após absorverem energia, passam de um estado orbital de alta energia (HOMO) para um orbital de baixa energia (LUMO). Esta transferência de estados orbitais tem influência no comprimento de onda e retorno ao estado fundamental após irradiação. A instabilidade, após a irradiação, modifica a estrutura formando o isômero cis, como consequência, compromete a absorção de raios UV. Entretanto, essa isomerização trans/cis não pode ser considerada como um mecanismo de instabilidade. A alteração estrutural, após irradiação, pode desencadear resposta eficiente na dispersão dos raios UV (CHATELAIN, GABARD, 2001; PERES et al., 2017; SANTOS, 2014).

Couteau e colaboradores (2007) avaliaram a fotoestabilidade de 18 fórmulas contendo filtros isolados, entre eles o octocrileno $10 \%$, metoxicinamato de octila $10 \%$ e o salicilato de octila $5 \%$. As fórmulas foram aplicadas em placas de PMMA e submetidas à irradiação artificial em câmara de fotoestabilidade. O octocrileno e o metoxicinamato de octila foram considerados fotoestáveis, de acordo com o tempo necessário, em horas de exposição, para o decaimento de $10 \%$ do FPS inicial. No entanto, o salicilato de octila, foi considerado fotoinstável, por não manter-se por um período mínimo de 2 horas (COUTEAU et al., 2007).

Apesar das diferenças estatísticas entre as médias da amostra F2, antes e após irradiação, este filtro é considerado estável. A amostra F3, composta por salicilato de octila e base, foi considerada instável quando comparado com os cinamatos, e a amostra F1 manteve-se estável, antes e após irradiação. O FPS diminuiu $14,9 \%, 42,3 \%$ e $50,0 \%$, respectivamente, para as amostras $\mathrm{F} 1$, F2, e F3 (COUTEAU et al., 2007; NICULAE et al., 2013; RODIL et al., 2009). 
5.5. Método analítico para a quantificação do aduto dialdeído malônico - ácido tiobarbitúrico (MDA-TBA)

\subsubsection{Curva analítica e Linearidade}

O ensaio de TBARS é um ensaio espectrofotométrico ou espectrofluorimétrico dos produtos gerados por formação do aduto MDA-TBA, entretanto, além do MDA, outros aldeídos podem reagir com MDA e interferir nas concentrações deste. A análise por CLAE melhora a especificidade e confiabilidade desta técnica e o aduto MDA-TBA é quantificado separadamente de outros cromóforos formados (BASTOS et al., 2012; HONG et al., 2000). A Tabela 8 apresenta os dados obtidos para a realização da curva analítica, sendo esta ilustrada na Figura 11. O método apresentou linearidade em função das áreas dos picos e as concentrações de MDA. A Tabela 9 apresenta a equação da reta e o coeficiente de correção linear. 
Tabela 8. Dados utilizados na construção da curva analítica.

\begin{tabular}{|c|c|c|c|c|}
\hline \multirow{2}{*}{$\begin{array}{l}\text { Concentração } \\
\text { teórica do aduto } \\
\text { MDA - TBA ( } \mu \mathrm{M})\end{array}$} & \multicolumn{4}{|c|}{ Área dos picos } \\
\hline & A1 & A2 & A3 & $A_{\text {média } \pm D P}$ \\
\hline 0,025 & 27387 & 22287 & 24444 & $24706,0 \pm 1787,3$ \\
\hline 0,05 & 31061 & 36767 & 41776 & $36534,7 \pm 3649,1$ \\
\hline 0,075 & 51266 & 52336 & 40834 & $48145,3 \pm 4874,2$ \\
\hline 0,1 & 50972 & 64956 & 59522 & $58483,3 \pm 5007,5$ \\
\hline 0,25 & 103797 & 113657 & 88009 & $101821,0 \pm 9208,0$ \\
\hline 0,5 & 168399 & 205245 & 196036 & $189893,3 \pm 14329,6$ \\
\hline 0,75 & 215546 & 256146 & 322003 & $264565,0 \pm 38292,0$ \\
\hline
\end{tabular}

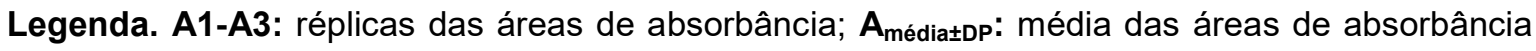
mais ou menos o desvio padrão. 
Figura 11. Curva analítica do aduto MDA-TBA.

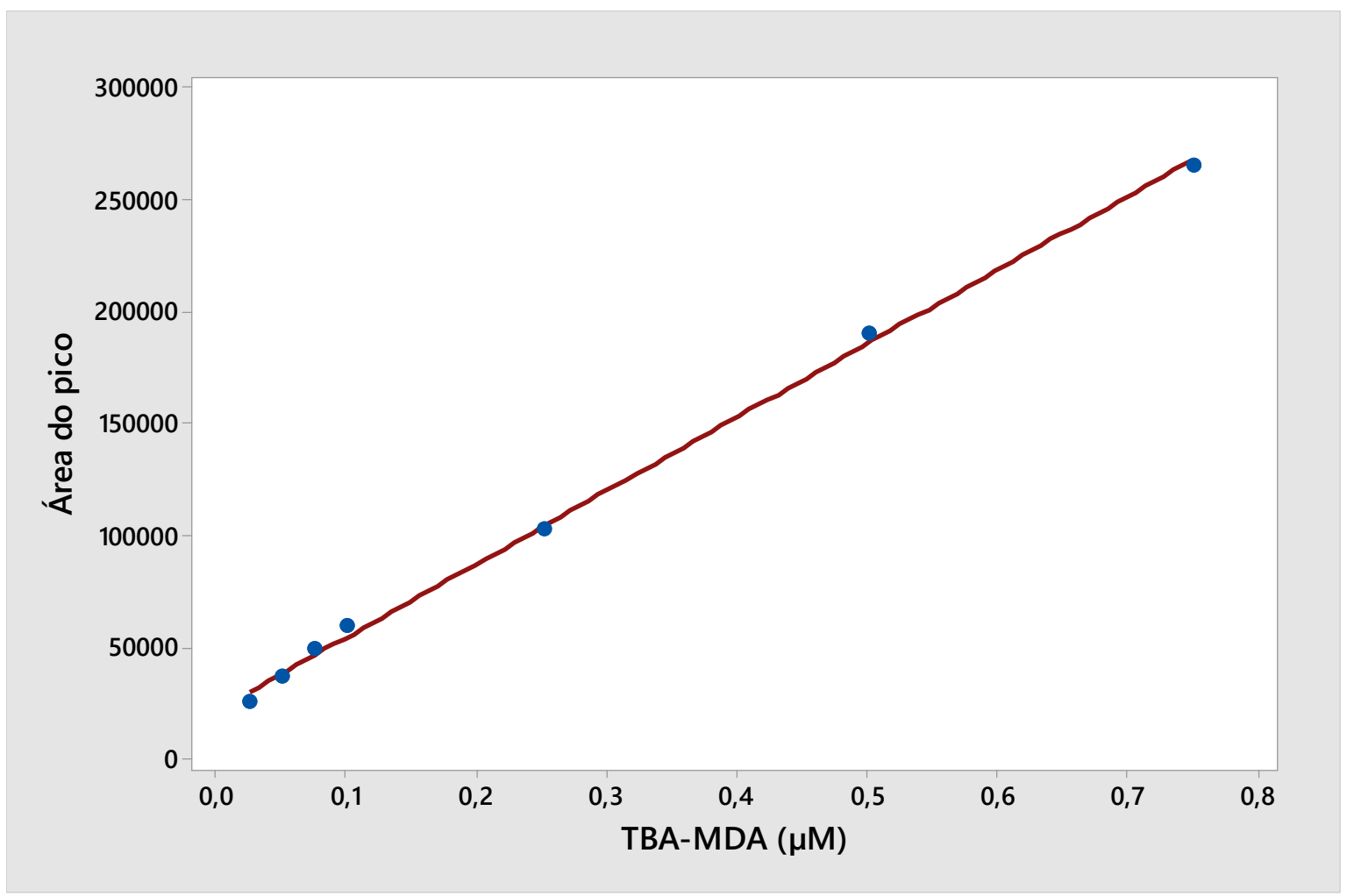

Legenda. As concentrações de MDA utilizadas na construção da curva foram 0,$025 ; 0,05 ; 0,075$; 0,$1 ; 0,25 ; 0,5 ; 0,75 \mu \mathrm{M}$, sendo o solvente branco, o metanol. O coeficiente de correlação linear utilizado foi $R^{2}=0,9984$ e a equação da reta é $y=21427+328092 x$.

Tabela 9. Linearidade de acordo com a análise da regressão

\begin{tabular}{c|c}
\hline \multicolumn{2}{|c}{ Regressão linear } \\
\hline Equação da reta & Área do pico =21427+328092(concentração do aduto TBA-MDA $\mu$ M) \\
\hline $\begin{array}{c}\text { Coeficiente de } \\
\text { correlação linear }\left(\mathbf{R}^{2}\right)\end{array}$ & 0,9984 \\
\hline
\end{tabular}

\subsubsection{Precisão}

A precisão foi calculada de acordo com a Equação 3 e os dados apresentados na Tabela 10 (TORMAN, COSTER, RIBOLDI, 2012). 
Tabela 10. Áreas dos picos e média utilizados na precisão.

\begin{tabular}{|c|c|c|c|c|}
\hline \multirow{2}{*}{$\begin{array}{l}\text { Concentração } \\
\text { teórica do aduto } \\
\text { MDA - TBA ( } \mu \text { M) }\end{array}$} & \multicolumn{4}{|c|}{ Área dos picos e média } \\
\hline & A1 & A2 & A3 & $A_{\text {média } \pm D P}$ \\
\hline 0,025 & 27387 & 22287 & 24444 & $24706 \pm 1787$ \\
\hline 0,05 & 31061 & 36767 & 41776 & $36535 \pm 3649$ \\
\hline 0,075 & 51266 & 52336 & 40834 & $48145 \pm 4874$ \\
\hline
\end{tabular}

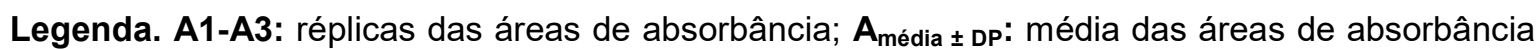
mais ou menos o desvio padrão.

A precisão encontrada foi de $30,3 \%$ entre as respostas de normalização das áreas dos picos (RIBANI et al., 2004).

\subsubsection{Especificidade}

O método mostrou-se capaz de medir o aduto MDA-TBA (leitura em $532 \mathrm{~nm}$ ). De acordo com a Figura 12, os picos encontrados durante a pesquisa de interferentes não ocorreram no mesmo tempo de retenção do aduto MDA-TBA (ALONSO et al., 2009). 
Figura 12. Cromatogramas individualmente sobrepostos dos interferentes do ensaio de TBARS.

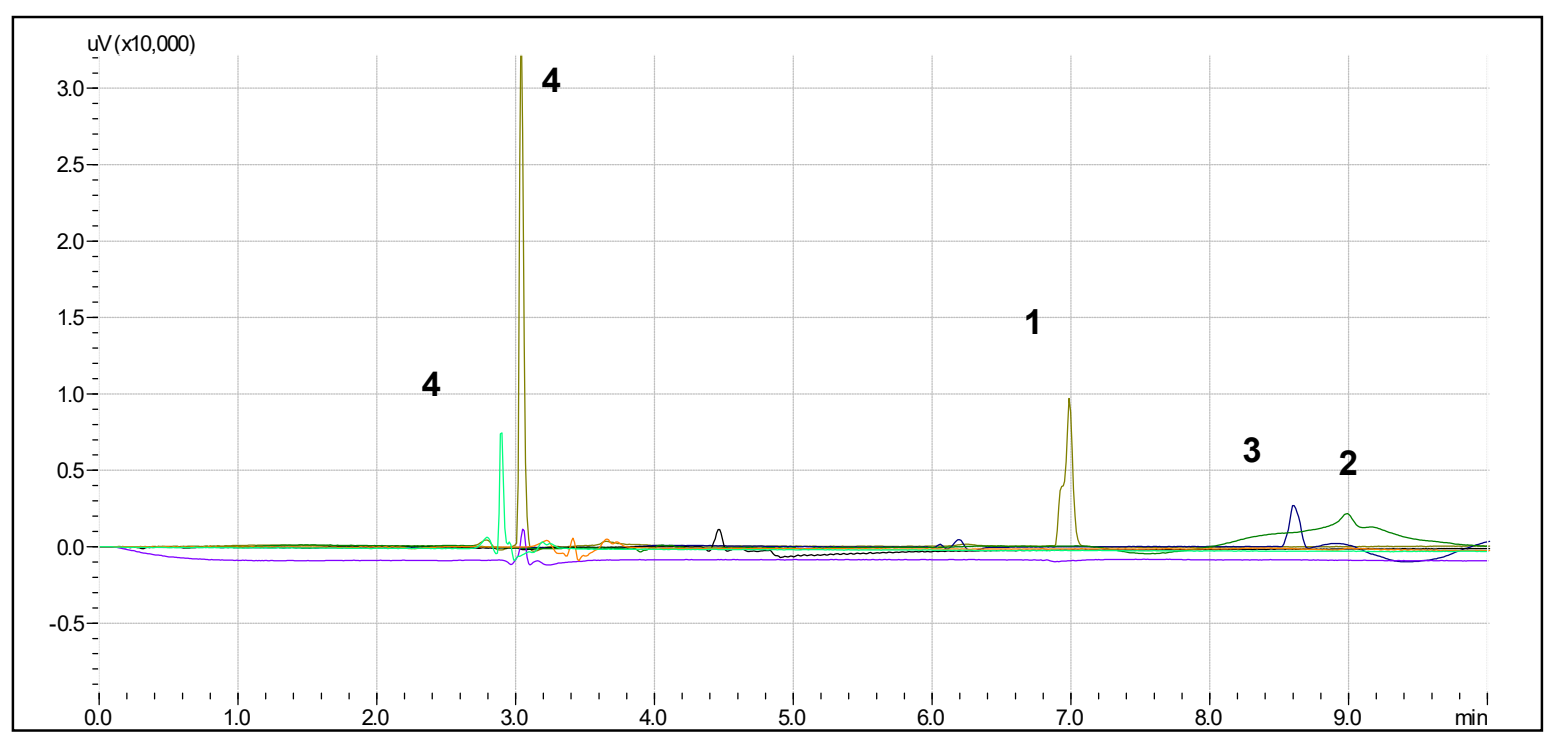

Legenda: 1: reação de TBARS; 2: fitas do tape stripping sem pele; 3: n-butanol; 4: sobreposição de cromatogramas de solventes utilizados no método $\left(0,2 \% \mathrm{BHT}, \mathrm{H}_{3} \mathrm{PO}_{4} 0,44 \mathrm{M}, 1 \% \mathrm{H}_{2} \mathrm{SO}_{4}\right)$ e das formulações com filtros.

\subsubsection{Exatidão}

A exatidão de um método analítico é a proximidade de um resultado obtido para o valor verdadeiro. A exatidão pode ser expressa pela taxa de recuperação de um resultado em função de uma concentração conhecida (CHANDRAN, SINGH, 2007).

A exatidão foi calculada conforme a Equação 4 e os valores encontrados foram analisados individualmente e de acordo com as médias das concentrações das réplicas. $O$ método possuiu valores de exatidão na faixa de especificação de concentração da tabela da AOAC. De acordo com as concentrações, os valores de recuperação do total das concentrações por réplica foram, respectivamente, $\mathrm{R} 1=89,82 \%, \mathrm{R} 2=111,95 \mathrm{R} 3=104,80$. As recuperações individuais e médias por concentração estão na Tabela 11 (AOAC, 2016; CHANDRAN, SINGH, 2007). 
Tabela 11. Recuperação das concentrações do aduto MDA-TBA

\begin{tabular}{|c|c|c|c|c|c|c|c|}
\hline \multirow{2}{*}{$\begin{array}{c}\text { Concentração } \\
\text { teórica do } \\
\text { aduto MDA - } \\
\text { TBA }(\mu \mathrm{M})\end{array}$} & \multicolumn{7}{|c|}{ Área dos picos e normalidade dos dados } \\
\hline & C1 ( $\mu \mathrm{M})$ & R1 (\%) & $\mathrm{C} 2(\boldsymbol{M M})$ & R2 (\%) & C3 ( $(\mu \mathrm{M})$ & R3 (\%) & $\begin{array}{l}\mathbf{R}(\%) \\
\text { média }\end{array}$ \\
\hline 0,05 & 0,0294 & 58,73 & 0,0468 & 93,51 & 0,0620 & 124,04 & 92,09 \\
\hline 0,075 & 0,0909 & 121,26 & 0,0942 & 125,61 & 0,0592 & 78,87 & 108,58 \\
\hline 0,1 & 0,0901 & 90,05 & 0,1327 & 132,67 & 0,1161 & 116,11 & 112,94 \\
\hline 0,25 & 0,2511 & 100,42 & 0,2811 & 112,44 & 0,2029 & 81,17 & 98,01 \\
\hline 0,5 & 0,4480 & 89,59 & 0,5603 & 112,05 & 0,5322 & 106,44 & 102,69 \\
\hline 0,75 & 0,5917 & 78,89 & 0,7154 & 95,39 & 0,9161 & 122,15 & 98,81 \\
\hline
\end{tabular}

Legenda. C1-C3: réplicas das concentrações expressão em $\mu \mathrm{M}$; R1-R3: recuperação conforme réplica da concentração expressa em porcentagem de recuperação; $\mathbf{R}(\%)$ média: recuperação média de cada concentração.

\subsection{Método tape stripping}

A quantificação do aduto de TBA-MDA foi realizada por meio da técnica de tape stripping, com modificações, conforme descrito por Alonso e colaboradores (2009). A quantificação da peroxidação lipídica, pelo aduto, teve como intuito avaliar as formulações com filtros solares e analisar a possível capacidade dos filtros de conter a peroxidação lipídica.

Foram selecionados nove voluntários, de acordo com os termos de inclusão e exclusão estabelecidos para o estudo, com idade entre 21 e 45 anos e fototipo de pele entre I e III. Após a retirada das fitas, não houve relato de sensação de desconforto e a camada córnea removida foi extraída com metanol para injeção em sistema CLAE. Os resultados de concentração, calculados 
conforme equação descrita na Tabela 9, estão descritos na Tabela 12 e expressos na Figura 13.

Tabela 12. Média das concentrações de adutos MDA-TBA nas amostras de tape stripping, do estrato córneo da pele sem formulação.

\begin{tabular}{c|c|c}
\hline \hline Formulações & Condição & $\begin{array}{c}\text { Concentração Média } \pm \\
\text { Desvio padrão }(\mu \mathrm{M})\end{array}$ \\
\hline BRANCO & IR & $0,08 \pm 0,02^{\mathrm{a}}$ \\
\hline BRANCO & $\mathrm{NI}$ & $0,02 \pm 0,02^{\mathrm{b}}$ \\
\hline \hline
\end{tabular}

Legenda. IR: Amostras irradiadas; NI: Amostras não irradiadas; BRANCO: Pele sem formulação. Os resultados não irradiados e irradiados foram avaliados de acordo com o teste $t$ pareado entre os valores (nível de significância $=0,05$ ). Letras diferentes na mesma coluna indicam diferença estatística significativa entre os resultados.

Figura 13. Gráfico de valores Individuais dispersos de concentração pela condição.

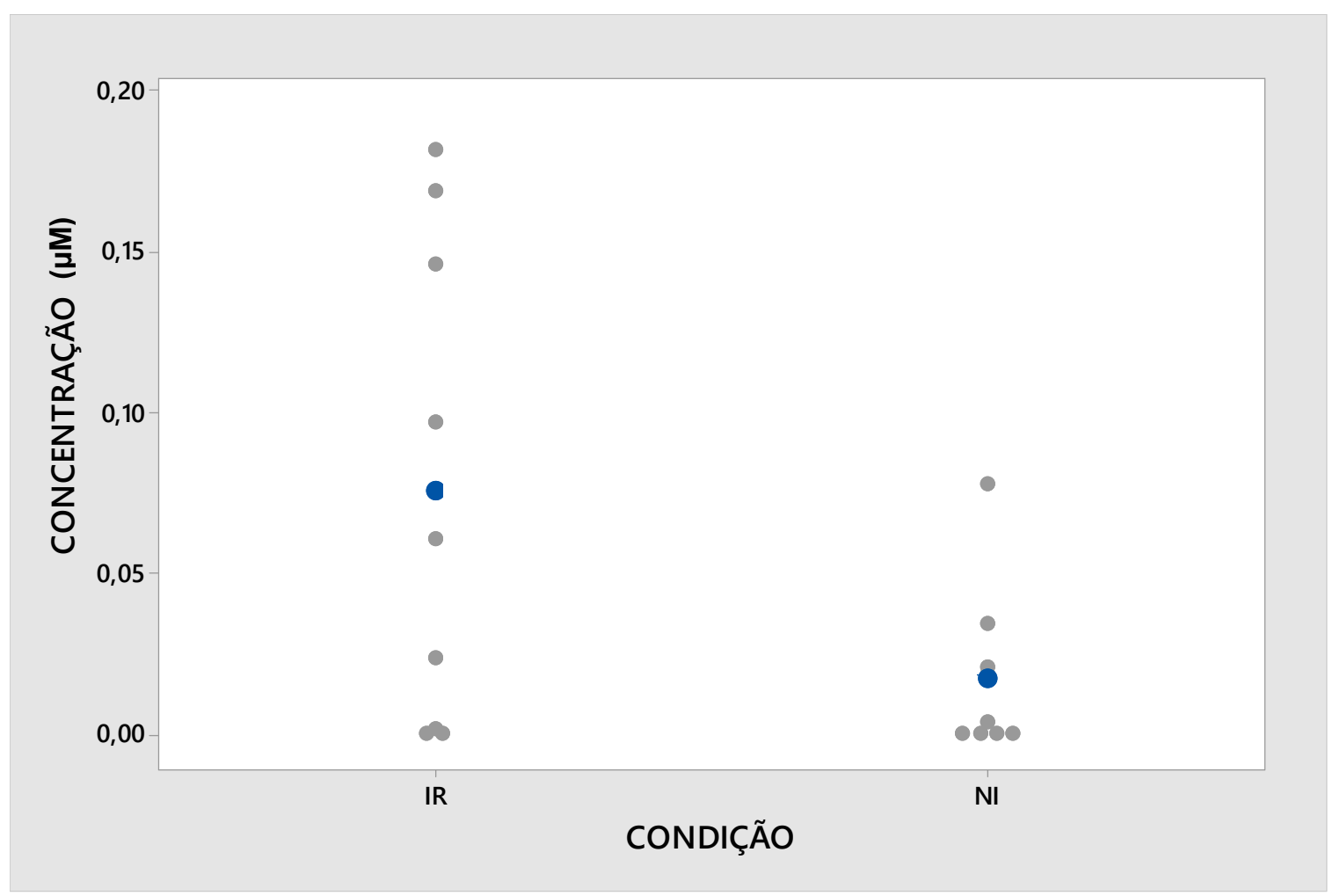

Legenda. IR: Amostras irradiadas de pele sem formulação; NI: Amostras não irradiadas de pele sem formulação. Os resultados não irradiados e irradiados foram avaliados de acordo com o teste ANOVA One Way por comparação Tukey entre os valores (nível de significância $=0,05$ ). 
Quando comparadas as amostras irradiadas com as não irradiadas houve diferenças significativas. A Figura 13 ilustra as médias dos dois grupos, pele irradiada e não irradiada, por meio da dispersão das concentrações obtidas nos voluntários. Devido à estrutura lipídica dérmica, a quantidade de peróxidos formados aumentou conforme a exposição à radiação. Houve maior formação de peróxidos nas amostras irradiadas (LADEMANN, 2009).

A pele executa duas essenciais funções, barreira contra estresse ambiental e regula a perda de água do corpo. A função barreira é determinada por estratificação tecidual que envolve a expressão programada e a reorganização de várias proteínas e estruturas. O resultado da diferenciação de queratinócitos é a camada córnea, formada por células mortas achatadas e envolvidas por lamelas lipídicas. Os corneócitos são completamente circundados por cadeias longas de ômega-hidroxi-ceramidas ligadas covalentemente, juntamente com ésteres de colesterol, esfingosina e ácidos graxos livres. O conteúdo lipídico do estrato córneo humano é de $50 \%$ de ceramidas, $25 \%$ de colesterol e $15 \%$ de ácidos graxos livres. Neste complexo lipídico uma variedade de hidrolases lipídicas e proteases compõem o sistema enzimático. A comparação estatística entre os grupos irradiados na pele, com formulação, foi realizada e os dados gerados estão dispostos na Tabela 13 (NATARAJAN et al., 2014; PERES, 2015). 
Tabela 13. Concentração média do aduto MDA-TBA nas amostras.

\begin{tabular}{c|c|c}
\hline Formulações & Condição & $\begin{array}{c}\text { Concentração Média } \pm \\
\text { Desvio padrão do aduto } \\
\text { MDA-TBA ( } \mu \text { M) }\end{array}$ \\
\hline F1 & IR & $0,07 \pm 0,07^{\mathrm{a}}$ \\
\hline F2 & IR & $0,04 \pm 0,05^{\mathrm{a}}$ \\
\hline F3 & IR & $0,10 \pm 0,07^{\mathrm{a}}$ \\
\hline F4 & IR & $0,06 \pm 0,06^{\mathrm{a}}$ \\
\hline F4 & NI & $0,04 \pm 0,06^{\mathrm{a}}$ \\
\hline \hline
\end{tabular}

Legenda. IR: Amostras irradiadas de pele com formulação; NI: Amostras não irradiadas de pele com formulação; F1: Base com octocrileno; F2: Base com metoxicinamato de octila; F3: Base com salicilato de octila; F4: Formulação base sem os filtros. Os resultados não irradiados e irradiados foram avaliados de acordo com o teste ANOVA One Way por comparação Tukey para comparação entre os cinco grupos diferentes (nível de significância $=0,05$ ). Letras diferentes na mesma coluna indicam diferença estatística significativa entre os resultados.

Houve tendência, nas médias, das formulações F1 $(0,07 \pm 0,07 \mu \mathrm{M})$ e F2 $(0,04 \pm 0,05 \mu \mathrm{M})$ em produzir menor resposta de peroxidação em relação ao extrato córneo irradiado sem proteção $(0,08 \pm 0,06 \mu \mathrm{M})$ ou só com a base sem filtros $(0,06 \pm 0,06 \mu \mathrm{M})$. Entretanto, provavelmente em função do desvio padrão, inerente à variabilidade genética e aos estudos com sujeitos, não se percebeu diferenças entre as amostras (NATARAJAN et al., 2014; PERES, 2015). 
Figura 14. Gráfico de comparação entre as médias das amostras com os valores individuais dispersos por grupo, somente amostras irradiadas.

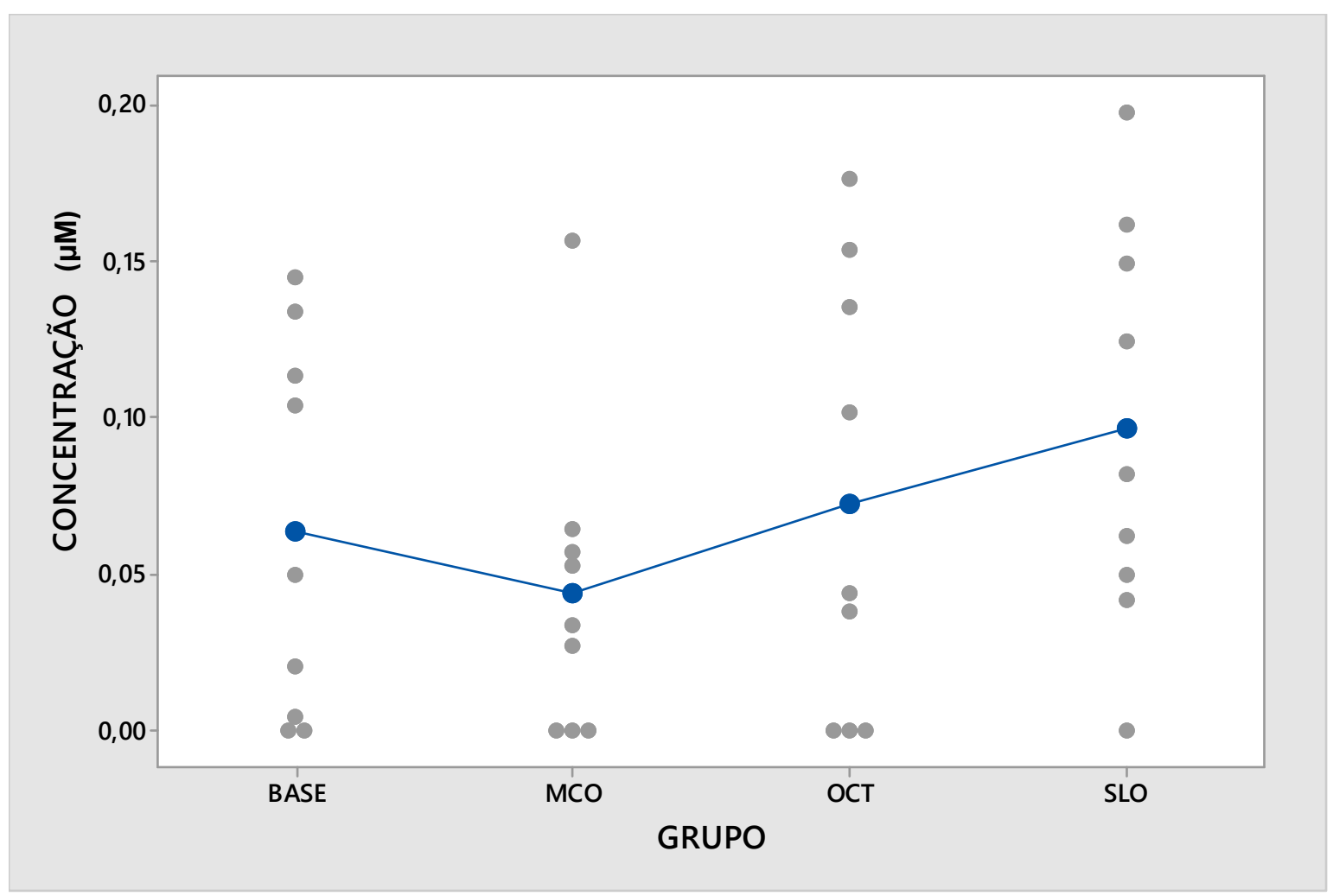

Legenda: OCT: Base com octocrileno; MCO: Base com metoxicinamato de octila; SLO: Base com salicilato de octila; BASE: Fórmula sem filtros.

Comparando as médias, na Figura 14, evidenciou-se uma menor formação de peróxidos pela média do grupo MCO. O MCO é bem tolerado e mundialmente usado em produtos de cuidados pessoais em saúde. Apesar de estudos relatando as possíveis atividades anti-inflamatórias do MCO e alguns dos seus derivados, há relatos de efeitos indesejados após aplicação tópica, como irritação da pele ou dermatite alérgica. Dos diversos produtos gerados da fotólise do $\mathrm{MCO}$, nem todos são tóxicos às células e sua capacidade de proteção perante à exposição solar, quando comparada com os filtros salicilato de octila e octocrileno é superior (KOMALA et al., 2018; STEIN et al., 2017).

Os raios eletromagnéticos interagem com os filtros orgânicos, absorvendo ou dispersando sua energia. Devido a sua capacidade de interagir com os raios UV, de acordo com a Figura 14, o salicilato de octila foi o filtro que menos impediu a produção de peróxidos lipídicos.

Os salicilatos têm a faixa ideal de absorção de filtros solares UVB, de 300-310 nm, no entanto, precisamente pela mesma razão, ou seja, a relação 
orto, eles têm um coeficiente de extinção baixo. A relação, entre o grupo fenólico e a função ester carboxílico, causa a tensão estérica, ou tensão de van der Waals na molécula toda, conforme Figura 15. Essa tensão de van der Waals faz com que a molécula desvie do planaridade, quanto maior o desvio menor o coeficiente de extinção $\left(€ / \mathrm{dm}^{3} \mathrm{~mol}^{-1} \mathrm{~cm}^{-1}\right)$. Este coeficiente é a capacidade de um mol da molécula de atenuar a luz incidida em determinado comprimento de onda (salicilato de octila $4130 € / \mathrm{dm}^{3} \mathrm{~mol}^{-1} \mathrm{~cm}^{-1}$ ) (SHAATH, 2005; WANG, LIM, 2016).

Figura 15. Deslocalização e ligação de hidrogênio através do plano da estrutura geral dos salicilatos.

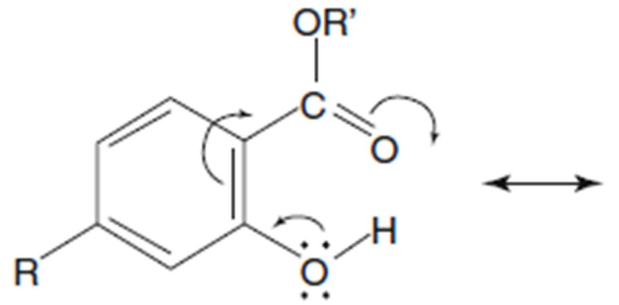<smiles></smiles>

Os cinamatos possuem uma insaturação extra conjugada, em ambos os compostos, nos anéis aromáticos e na porção carbonila do éster carboxílico. Esta configuração permite a deslocalização de elétrons em toda a molécula, Figura 16. A energia correspondente a esta transição eletrônica tem um comprimento de onda de cerca de $310 \mathrm{~nm}$ e um coeficiente de extinção molar maior (metoxicinamato de octila $23300 € / \mathrm{dm}^{3} \mathrm{~mol}^{-1} \mathrm{~cm}^{-1}$; octocrileno $12290 € / \mathrm{dm}^{3}$ $\mathrm{mol}^{-1} \mathrm{~cm}^{-1}$ ) (GARCIA et al, 2015; SHAATH, 2005; SHAATH, 2010; WANG, LIM, 2016).

Figura 16. Deslocalização de elétron em molécula de cinamato.<smiles>[R]OC(=O)C=Cc1ccc(OC)cc1</smiles><smiles>[R]O/C([O-])=C/C=C1C=CC(=[O+]C)C=C1</smiles>

O coeficiente de extinção define o quão fortemente uma molécula absorve radiação em uma determinada frequência. A média, da concentração de adutos de MDA-TBA encontrados, corresponde aos valores de coeficiente molar 
de cada um dos filtros e aos valores de FPS encontrados in vitro, Tabela 14 (SHAATH, 2005; SHAATH, 2010).

Tabela 14. Resultados de FPS, comprimento de onda crítico e concentração do aduto MDA-TBA e valores de coeficiente de extinção molar da literatura.

\begin{tabular}{c|c|c|c|c}
\hline \hline \multirow{2}{*}{ Formulações } & \multicolumn{2}{|c|}{$\begin{array}{c}\text { Fator de Proteção Estimado } \\
\text { (FPS) }\end{array}$} & $\begin{array}{c}\text { Coeficiente de } \\
\text { extinção molar } \\
\left(\boldsymbol{\epsilon} / \mathrm{dm}^{3} \mathbf{m o l}^{-1} \mathbf{c m}^{-1}\right)\end{array}$ & $\begin{array}{c}\text { Concentração } \\
\text { Média } \pm \text { Desvio } \\
\text { padrão do aduto } \\
\text { MDA-TBA }(\mu \mathrm{M})\end{array}$ \\
\cline { 2 - 5 } & Pré-Irradiação & Pós-irradiação & 4130 & $0,10 \pm 0,07$ \\
\hline F3 & $1,9 \pm 0,2$ & $1,0 \pm 0,0$ & 12290 & $0,07 \pm 0,07$ \\
\hline F1 & $6,7 \pm 2,1$ & $5,7 \pm 2,1$ & 23300 & $0,04 \pm 0,05$ \\
\hline \hline
\end{tabular}

Legenda: F1: Base com octocrileno; F2: Base com metoxicinamato de octila; F3: Base com salicilato de octila.

A formulação com melhor desempenho, de acordo com as médias, foi a F2, seguida das formulações F1 e F3. De acordo com a Tabela 14, quanto maior o FPS e o coeficiente de extinção molar, menor a concentração de adutos de MDA-TBA, ou seja, menor a produção de peróxidos.

Os filtros não apresentaram atividade inibidora da peroxidação lipídica perante a exposição à radiação solar artificial. Os resultados demonstraram o potencial do método com relação à quantificação da peroxidação lipídica na pele. 


\section{CONCLUSÕES}

Foram preparados sistemas emulsionados contendo os filtros octocrileno, metoxicinamato de octila e salicilato de octila biocompatíveis com a pele. As características organolépticas e físico-químicas das amostras apresentaram-se adequadas. Todas as formulações foram estáveis frente aos testes de centrifugação e estresse térmico.

A eficácia in vitro das preparações fotoprotetoras foi realizada por meio da espectrofotometria de refletância difusa com esfera de integração e a F2, base com metoxicinamato de octila, demonstrou o maior valor de FPS. A amostra F1, base com octocrileno, apresentou-se estável perante a exposição artificial à radiação UV.

O método por CLAE, para quantificação da peroxidação lipídica no estrato córneo, possuiu linearidade e demonstrou especificidade, exatidão e precisão satisfatórias.

O estresse pela radiação UV desencadeia a peroxidação lipídica na pele. Em função do protocolo aplicado, não houve diferenças entre as amostras, a eficácia, com relação a inibição da peroxidação lipídica, foi similar em todas as amostras. Os resultados sugerem que os filtros solares são capazes de impedir a peroxidação lipídica. 


\section{REFERÊNCIAS ${ }^{1}$}

AGRAPIDIS-PALOYMPIS, L. E.; NASH, R. A.; SHAATH, N. A. The effect of solvents on the ultraviolet absorbance of sunscreens. Journal of The Society of Cosmetic Chemist, v. 38, p. 209-221, 1987.

ALONSO, C. et al. An ex vivo methodology to assess the lipid peroxidation in stratum corneum. Journal of Photochemistry and Photobiology B: Biology, v. 97, n. 2, p. 71-76, 2009.

ALVES L.F. et al. A chromophoric study of 2-ethylhexyl p-methoxycinnamate. Chemical Physics Letters, v. 516, n. 4, p. 162-165, 2011.

American Association of Official Analytical Chemists (AOAC) Appendix F: Guidelines for standard method performance requirements. Official Methods of Analysis. Arlington, United States of America (2016).

AXELSTAD M. et al. Effects of pre-and postnatal exposure to the UV-filter octyl methoxycinnamate (MCO) on the reproductive, auditory and neurological development of rat offspring. Toxicology and applied pharmacology, v. 250, n. 3, p. 278-290, 2011.

AYALA, A.; MUÑOZ, M. F.; ARGÜELLES, S. Lipid peroxidation: production, metabolism, and signaling mechanisms of malondialdehyde and 4-hydroxy-2nonenal. Oxidative medicine and cellular longevity, v. 2014, 2014.

BABY, A.R. Avaliação in vitro da permeabilidade cutânea da rutina em emulsões cosméticas. São Paulo. 2007. 144 f. Tese (Doutorado) - Faculdade de Ciências Farmacêuticas, Universidade de São Paulo, São Paulo, 2007.

BABY, A.R. et al. Estabilidade e estudo de penetração cutânea in vitro da rutina veiculada em uma emulsão cosmética através de um modelo de biomembrana alternativo. Revista Brasileira de Ciências Farmacêuticas, v.44, n.2, p.233-248, 2008.

BABY, A.R. et al. Spectroscopic and termal characterization of alternative model biomembranes from shed skins of Bothrops jararaca and Spilotis pullatus. Brazilian Journal of Pharmaceutical Sciences, v. 45, n. 3, p. 423-428, 2009.

BAKER, L A.; HORBURY, M. D.; STAVROS, V. G. Ultrafast photoprotective properties of the sunscreening agent octocrylene. Opticsexpress, v. 24, n. 10, p. 10700-10709, 2016.

BALOGH, T.S. et al. Proteção à radiação ultravioleta: recursos disponíveis na atualidade em fotoproteção. Anais Brasileiros de Dermatologia, v. 86, n. 4, p. 73242, 2011.

BARRERA, G. et al. Lipid peroxidation-derived aldehydes, 4-hydroxynonenal and malondialdehyde in aging-related disorders. Antioxidants, v. 7, n. 8, p. 102, 2018.

\footnotetext{
${ }^{1}$ De acordo com a NBR 6023/2002 preconizada pela ASSOCIAÇÃO BRASILEIRA DE NORMAS TÉCNICAS (ABNT).
} 
BASTOS, A.S. et al. Quantitation of malondialdehyde in gingival crevicular fluid by a high-performance liquid chromatography-based method. Analytical biochemistry, v. 423, n. 1, p. 141-146, 2012.

BERNEBURG, M. et al. Singlet oxygen mediates the UVA-induced generation of the photoaging-associated mitochondrial common deletion. Journal of Biological Chemistry, v. 274, n. 22, p. 15345-15349, 1999.

BLÜTHGEN N. et al. Accumulation and effects of the UV-filter octocrylene in adult and embryonic zebrafish (Danio rerio). Science of the Total Environment, v. 476, p. 207-217, 2014.

BONDET, V.; BRAND-WILLIAMS, W.; BERSET, C. Kinetics and mechanisms of antioxidant activity using the DPPH $\bullet$. free radical method. LWT-Food Science and Technology, v. 30, n. 6, p. 609-615, 1997.

BRASIL. Agência Nacional de Vigilância Sanitária (ANVISA). Resolução RDC $n^{\circ}$ 47, de 16 de março de 2006. Diário Oficial da República Federativa do Brasil, Poder Executivo, Brasília.

BRASIL. Agência Nacional de Vigilância Sanitária (ANVISA). Resolução RDC n.30, de 01 de junho de 2012a. Diário Oficial da República Federativa do Brasil, Poder Executivo, Brasília.

BRASIL. Agência Nacional de Vigilância Sanitária. Resolução R.E. n.899, de 29 de maio de 2003. Determina a publicação do "Guia para validação de métodos analíticos e bioanalíticos". Diário Oficial da República Federativa do Brasil, Poder Executivo, Brasília.

BRASIL. Ministério da Saúde. Agência Nacional de Vigilância Sanitária. Guia de estabilidade de produtos cosméticos. Brasília, 2004, v.1, 45p.

BRASIL. Ministério da Saúde. Agência Nacional de Vigilância Sanitária. Guia para avaliação de segurança de produtos cosméticos. Brasília, 2012c, v.1, 74p.

BRASIL. Ministério da Saúde. Conselho Nacional de Saúde. Resolução n 466, de 12 de dezembro de 2012b. Diário Oficial da República Federativa do Brasil, Poder Executivo, Brasília.

BREMOND, N.; THIAM, A.R.; BIBETTE, J. Decompressing emulsion droplets favors coalescence. Physical review letters, v. 100, n. 2, p. 024501, 2008.

BRIASCO B. et al. Stability Study of Sunscreens with Free and Encapsulated UV Filters Contained in Plastic Packaging. Pharmaceutics, v. 9, n. 2, p. 19, 2017.

BUEGE, J.A.; AUST, S.D. Microsomal lipid peroxidation. Methods Enzymol. 52, 302-310.1978.

CHANDRAN, S; SINGH, R.S.P. Comparison of various international guidelines for analytical method validation. Die Pharmazie-An International Journal of Pharmaceutical Sciences,62 (1), 4-14 (2007). 
CHANG, N. et al. Skin cancer incidence is highly associated with ultraviolet-B radiation history. International journal of hygiene and environmental health, v. 213, n. 5, p. 359-368, 2010.

CHATELAIN, E.; GABARD, B. Photostabilization of Butyl methoxydibenzoylmethane (Avobenzone) and Ethylhexyl methoxycinnamate by Bis-ethylhexyloxyphenol methoxyphenyl triazine (Tinosorb S), a New UV Broadband Filter. Photochemistry and Photobiology, v. 74, n. 3, p. 401-406, 2001.

CHOQUENET, B. et al. Flavonoids and polyphenols, molecular families with sunscreen potential: determining effectiveness with an in vitro method. Natural Products Communication, v. 4, n. 2, p. 227-230, 2009.

CLARIANT, ARISTOFLEX ${ }^{\circledR}$ Polymers. 6p. 2013.

COLIPA Guidelines. International sun protection factor (SPF) test method. Auderghem: COLIPA, CTFA, SA, JCIA, 2006. 46p.

COLIPA. Guidelines. Method for in vitro determination of UVA protection: In vitro method for the determination of the UVA protection factor and "critical wavelength" values of sunscreen products, 2011, 28p.

COLIPA. Guidelines. Product test guidelines for the assessment of human skin compatibility. Brussels, 1997,26 p.

COUTEAU, C. et al. Study of the photostability of 18 sunscreens in creams by measuring the SPF in vitro. Journal of pharmaceutical and biomedical analysis, $v$. 44, n. 1, p. 270-273, 2007.

DAMIANI, E.; BASCHONG, W.; GRECI, L. UV-Filter combinations under UV-A exposure: Concomitant quantification of over-all spectral stability and molecular integrity. Journal of Photochemistry and Photobiology B: Biology, v. 87, n. 2, p. 95104, 2007.

DICKEL, H. et al. Standardized Tape Stripping: A Practical and Reproducible Protocol to Reduce Uniformly the Stratum Corneum. Agache's Measuring the Skin: Non-invasive Investigations, Physiology, Normal Constants, p. 289-297, 2017.

ESCOBAR-CHAVEZ, J.J. et al. The tape-stripping technique as a method for drug quantification in skin. Journal of pharmacy \& pharmaceutical sciences, v. 11, n. 1 , p. 104-130, 2008.

EZERSKAIA, A. et al. Quantification of changes in skin hydration and sebum after tape stripping using Infrared spectroscopy. In: Photonics in Dermatology and Plastic Surgery. International Society for Optics and Photonics, 401-407, 2017.

FILIP A. et al. The effects of grape seeds polyphenols on SKH-1 mice skin irradiated with multiple doses of UV-B. Journal of Photochemistry and Photobiology B: Biology, v. 105, n. 2, p. 133-142, 2011.

FIROOZ A. et al. Daytime changes of skin biophysical characteristics: A study of hydration, transepidermal water loss, ph, sebum, elasticity, erythema, and color 
index on middle eastern skin. Indian journal of dermatology, v. 61, n. 6, p. 700, 2016.

FITZPATRICK, T. B. The validity and practicality of sun-reactive skin types I through VI. Archives of dermatology, v. 124, n. 6, p. 869-871, 1988.

FLOR, J.; DAVOLOS, M.R. CORREA, M.A. Protetores solares. Química Nova, p. 153-158, 2007.

FORESTIER, S. Rationale for sunscreen development. Journal of the American Academy of Dermatology, v. 58, n. 5, p. S133-S138, 2008.

FRANTZEN, M. et al. Biological effects of mechanically and chemically dispersed oil on the Icelandic scallop (Chlamys islandica). Ecotoxicology and Environmental Safety, v. 127, p. 95-107, 2016.

FRISING, T. NOÏK, C; DALMAZZONE, C. The liquid/liquid sedimentation process: from droplet coalescence to technologically enhanced water/oil emulsion gravity separators: a review. Journal of dispersion science and technology, v. 27, n. 7, p. 1035-1057, 2006.

GALVÃO, K. C. S. Desenvolvimento de nanoemulsões para uso em alimentos e uso tópico. 2015. 213f. Tese (Doutorado). Faculdade de Zootecnia e Engenharia de Alimentos - Universidade de São Paulo, Pirassununga, 2015.

GARCIA, R. D. et al. Benchmark studies of UV-vis spectra simulation for cinnamates with UV filter profile. Journal of molecular modeling, v. 21, n. 6, p. 150, 2015.

GASCHLER, M.M.; STOCKWELL, B.R. Lipid peroxidation in cell death. Biochemical and biophysical research communications, v. 482, n. 3, p. 419-425, 2017.

GHANI, M. A. et al. Measurement of antioxidant activity with the thiobarbituric acid reactive substances assay. Food chemistry, v. 230, p. 195-207, 2017.

GILBERT, E. et al. Commonly used UV filter toxicity on biological functions: review of last decade studies. International journal of cosmetic science, v. 35, n. 3, p. 208-219, 2013.

HANSON K.M. et al. Photochemical degradation of the UV filter octyl methoxycinnamate in solution and in aggregates. Photochemical \& Photobiological Sciences, v. 14, n. 9, p. 1607-1616, 2015.

HONG, Y. et al. Total plasma malondialdehyde levels in 16 Taiwanese college students determined by various thiobarbituric acid tests and an improved highperformance liquid chromatography-based method. Clinical biochemistry, v. 33, n. 8, p. 619-625, 2000.

IKEHATA, H.; ONO, T. The mechanisms of UV mutagenesis. Journal of radiation research, v. 52, n. 2, p. 115-125, 2011. 
JANERO, D. R. Malondialdehyde and thiobarbituric acid-reactivity as diagnostic indices of lipid peroxidation and peroxidative tissue injury. Free Radical Biology and Medicine, v. 9, n. 6, p. 515-540, 1990.

JANG H. et al. Skin pH is the master switch of kallikrein 5-mediated skin barrier destruction in a murine atopic dermatitis model. Journal of Investigative Dermatology, v. 136, n. 1, p. 127-135, 2016.

JANJUA N.R. et al. Systemic absorption of the sunscreens benzophenone-3, octyl-methoxycinnamate, and 3- (4-methyl-benzylidene) camphor after whole-body topical application and reproductive hormone levels in humans. Journal of Investigative Dermatology, v. 123, n. 1, p. 57-61, 2004.

JENTZSCH F. et al. Photodegradation of the UV filter ethylhexyl methoxycinnamate under ultraviolet light: Identification and in silico assessment of photo-transformation products in the context of grey water reuse. Science of the Total Environment, v. 572, p. 1092-1100, 2016.

JIMÉNEZ-DÍAZ I. et al. Simultaneous determination of the UV-filters benzyl salicylate, phenyl salicylate, octyl salicylate, homosalate, 3-(4-methylbenzylidene) camphor and 3-benzylidene camphor in human placental tissue by LC-MS/MS. Assessment of their in vitro endocrine activity. Journal of Chromatography B, v. 936, p. 80-87, 2013.

KARPKIRD, T. M.; WANICHWEACHARUNGRUANG, S.; ALBINSSON, B. Photophysical characterization of cinnamates. Photochemical \& Photobiological Sciences, v. 8, n. 10, p. 1455-1460, 2009.

KOMALA, I. et al. Structure-Activity Relationship Study on the Ethyl pMethoxycinnamate as an Anti-Inflammatory Agent. Indonesian Journal of Chemistry, v. 18, n. 1, p. 60-65, 2018.

KRAUSE M. et al. Sunscreens: are they beneficial for health? An overview of endocrine disrupting properties of UV-filters. International journal of andrology, $v$. 35, n. 3, p. 424-436, 2012.

KRISHNAN R. et al. Optical spectroscopy of hydrophobic sunscreen molecules adsorbed to dielectric nanospheres. Photochemistry and photobiology, v. 79, n. 6 , p. 531-539, 2004.

KUNZ M. et al. Elevated serum superoxide dismutase and thiobarbituric acid reactive substances in different phases of bipolar disorder and in schizophrenia. Progress in Neuro-Psychopharmacology and Biological Psychiatry, v. 32, n. 7, p. 1677-1681, 2008.

LADEMANN, J. et al. The tape stripping procedure-evaluation of some critical parameters. European Journal of Pharmaceutics and Biopharmaceutics, v. 72, n. 2, p. 317-323, 2009.

LEPHART, E. D. Skin aging and oxidative stress: Equol's anti-aging effects via biochemical and molecular mechanisms. Ageing research reviews, v. 31, p. 36-54, 2016. 
LEVI, K. UV damage and sun care: deciphering mechanics of skin to develop next generation therapies. Journal of the Mechanical Behavior of Biomedical Materials, v. 28, p. 471-473, 2013.

Liu X.H. et al. Preparation and evaluation of novel octyl methoxycinnamate-loaded solid lipid nanoparticles. International journal of cosmetic science, v. 37, n. 4, p. 446-453, 2015.

LOPES, F.M.; CRUZ, R.O.; BATISTA, K.A. Radiação ultravioleta e ativos utilizados nas formulações de protetores solares. Ensaios e Ciência: C. Biológicas, Agrárias e da Saúde, v. 16, n. 4, 2015.

MOHAN, S.V.; CHANG, A.L.S. Advanced basal cell carcinoma: epidemiology and therapeutic innovations. Current Dermatology Reports, v. 3, n. 1, p. 40-45, 2014.

NASCIMENTO, L. F.; SANTOS, E. P.; AGUIAR, A. P. Fotoprotetores orgânicos: Pesquisa, Inovação e a Importância da Síntese orgânica. Revista Virtual de Química, v. 6, n. 2, p. 190-223, 2013.

NATARAJAN, V. T. et al. Multifaceted pathways protect human skin from UV radiation. Nature chemical biology, v. 10, n. 7, 2014.

NICULAE, G. et al. Coencapsulation of butyl-methoxydibenzoylmethane and octocrylene into lipid nanocarriers: UV performance, photostability and in vitro release. Photochemistry and photobiology, v. 89, n. 5, p. 1085-1094, 2013.

OLIVEIRA, C.A. Desenvolvimento, avaliação da segurança e eficácia clínica de sistemas nanoparticulados de gelatina contendo rutina. São Paulo. 2015. 190p. Tese (Doutorado) - Faculdade de Ciências Farmacêuticas, Universidade de São Paulo, São Paulo, 2015.

OLIVEIRA, C.A. et al. Functional photostability and cutaneous compatibility of bioactive UVA suncare products. Journal of Photochemistry and Photobiology B: Biology, v. 148, p. 154-159, 2015.

OLIVEIRA, M.A.C; ISAAC, V.L.B. Synthesis and evaluation of new organic uv filters for prevention skin cancer. World journal of pharmacy and pharmaceutical sciences. V., p. 10, 1-11 2016.

PALM, M. D.; O'DONOGHUE, M. N. Update on photoprotection. Dermatol Ther, v. 20, p. 360-376, 2007.

PATTANAARGSON, S.; LIMPHONG, P. Stability of octyl methoxycinnamate and identification of its photo-degradation product. International journal of cosmetic science, v. 23, n. 3, p. 153-160, 2001.

PEREIRA, M. et al. Fotoestabilização de protectores solares por incorporação de chás como fase externa. Jornal de Investigação Biomédica e Biofarmacêutica, $n$ (12) 1, 107-116, 2015.

PERES, D.D. Ácido ferúlico em protetores solares: desenvolvimento e eficácia multifuncional in vitro, ex vivo e in vivo. São Paulo. 2015. 168p. Tese (Doutorado) 
- Faculdade de Ciências Farmacêuticas, Universidade de São Paulo, São Paulo, 2015.

PERES, D.D. et al. Hydrolyzed collagen interferes with in vitro photoprotective effectiveness of sunscreens. Brazilian Journal of Pharmaceutical Sciences, v. 53, n. 2, 2017.

PERUZZI, M.F. et al. Avaliação da atividade antioxidante pela inibição da peroxidação lipídica e quelação de íon ferro de extratos metanólicos de Azadirachta indica (NEEM), p. 17-19 . In: In Anais do V Simpósio de Bioquímica e Biotecnologia - VSIMBBTEC. Blucher Biochemistry Proceedings. São Paulo: Blucher, 2015.

PESCIA, A.C. et al. On the assessment of photostability of sunscreens exposed to UVA irradiation: From glass plates to pig/human skin, which is best?. International Journal of Pharmaceutics, v. 427, n. 2, p. 217-223, 2012.

POLONINI, H.C. et al. Synthesis and evaluation of octocrylene-inspired compounds for UV-filter activity. Química Nova, v. 37, n. 6, p. 1004-1009, 2014.

POPRAC P. et al. Targeting Free Radicals in Oxidative Stress-Related Human Diseases. Trends in Pharmacological Sciences, 2017.

RAMOS, P.F.; GIARDINI, I.J.M. Estudo comparativo de formulações de fator de proteção solar de farmácias magistrais utilizando simuladores. Infarma-Ciências Farmacêuticas, v. 26, n. 4, p. 251-257, 2014.

RIBANI, M. et al. Validação em métodos cromatográficos e eletroforéticos. Química nova, Vol. 27, No. 5, 771-780, 2004.

RIBEIRO, R. P. Desenvolvimento e validação da metodologia de análise do teor de filtros solares e determinação do FPS in vitro em formulações fotoprotetoras comerciais. 2004. 92p. Dissertação (Mestrado em Ciências Farmacêuticas) Faculdade de Farmácia, Universidade Federal do Rio de Janeiro, Rio de Janeiro, 2004.

RIBEIRO, S.M.R. et al. A formação e os efeitos das espécies reativas de oxigênio no meio biológico. Bioscience Journal, v. 21, n. 3, 2006.

RODIL, R. et al. Photostability and phytotoxicity of selected sunscreen agents and their degradation mixtures in water. Analytical and bioanalytical chemistry, v. 395, n. 5 , p. 1513, 2009.

RODRIGUES, N.D.N.; STANIFORTH, M.; STAVROS, V.G. Photophysics of sunscreen molecules in the gas phase: a stepwise approach towards understanding and developing next-generation sunscreens. In: Proc. R. Soc. A. The Royal Society, 2017. p. 20160677.

ROGERS H.W. et al. Incidence estimate of non melanoma skin cancer (keratinocyte carcinomas) in the US population, 2012. JAMA Dermatology, v. 151, n. 10, p. 1081-1086, 2015. 
RUSZKIEWICZ, J. A. et al. Neurotoxic effect of active ingredients in sunscreen products, a contemporary review. Toxicology Reports, 2017.

SAMBANDAN, D.R.; RATNER, D. Sunscreens: an overview and update. Journal of the American Academy of Dermatology, v. 64, n. 4, p. 748-758, 2011.

SANTOS, J.S. Desenvolvimento de formulações fotoprotetoras contendo filtros solares nanoencapsulados. 2014. 204f. Tese (Doutorado). Faculdade de Farmácia da Universidade Federal do Rio Grande do Sul. Porto Alegre, 2014

SARRUF, F. D. et al. Assessment of in vitro Sun Protection Factor (SPF) and rheological profile of commercial infant sunscreens. Journal of Basic and Applied Pharmaceutical Sciences, v. 34, n. 1, p. 33-36, 2013.

SCHLUMPF $\mathrm{M}$. et al. In vitro and in vivo estrogenicity of UV screens. Environmental health perspectives, v. 109, n. 3, p. 239, 2001.

SCHULTZ, S. et al. High-pressure homogenization as a process for emulsion formation. Chemical Engineering \& Technology: Industrial Chemistry-Plant Equipment-Process Engineering-Biotechnology, v. 27, n. 4, p. 361-368, 2004.

SEITÉ, S. et al. Broad-spectrum moisturizer effectively prevents molecular reactions to UVA radiation. Cutis, v. 90, n. 6, p. 321-326, 2012.

SELJESKOG, E.; HERVIG, T.; MANSOOR, M. A. A novel HPLC method for the measurement of thiobarbituric acid reactive substances (TBARS). A comparison with a commercially available kit. Clinical Biochemistry, v. 39, n. 9, p. 947-954, 2006.

SHAATH, N. A. Ultraviolet filters. Photochemical \& Photobiological Sciences, v. 9, n. 4, p. 464-469, 2010.

SHAATH, N. Sunscreens: Regulations and Commercial Development, Third Edition (Cosmetic Science and Technology Series). United States of America. Taylor \& Francis Group, 2005.

SHIVHARE, M.; MCCREATH, G. Practical considerations for DoE implementation in quality by design. Bio Process International, v. 8, n. 6, p. 22-30, 2010.

SIEGEL, R.L.; MILLER, K.D.; JEMAL, A. Cancer statistics, 2016. CA: A cancer journal for clinicians, v. 66, p. 7-30, 2016.

SPRINGSTEEN, A. et al. In vitro measurement of sun protection factor of sunscreens by diffuse transmittance. Analytica Chimica Acta, v.380, n.2/3, p.155164, 1999.

STEIN, H.V. et al. Photolysis and cellular toxicities of the organic ultraviolet filter chemical octyl methoxycinnamate and its photoproducts. Environmental Science: Processes \& Impacts, v. 19, n. 6, p. 851-860, 2017.

STERN, R.S. Prevalence of a history of skin cancer in 2007: results of an incidence-based model. Archives of Dermatology, v. 146, n. 3, p. 279-282, 2010. 
SVOBODOVA A.; WALTEROVA D.; VOSTALOVA J. Ultraviolet light induced alteration to the skin. Biomedical Papers-Palacky University in Olomouc, v. 150, n. 1, p. 25, 2006.

THIELE, J.J. et al. The Antioxidant Network of the Stratum corneum. Current Problems in Dermatology. Oxidants and Antioxidants in Cutaneous Biology, v. 29, p 26-42, 2001.

TORMAN, V.B.; COSTER, R.; RIBOLDI, J. Normalidade de variáveis: métodos de verificação e comparação de alguns testes não paramétricos por simulação. Revista HCPA. Porto Alegre. Vol. 32, №. 2, p. 227-234, 2012.

UNITED STATES (U.S). FOOD AND DRUG ADMINISTRATION (FDA). Department of Health and Human Services. 21 CRF parts 347 and 352. Sunscreen drug products for over-the-counter human use. $2015 \mathrm{a}$.

UNITED STATES (U.S.). FOOD AND DRUG ADMINISTRATION (FDA). Department of Health and Human Services. 21 CFR Parts 201 and 310. Labeling and effectiveness testing; sunscreen drug products for over-the- counter human use. $2015 b$.

UNITED STATES OF AMERICA (U.S.A) International Conference on Harmonisation Guideline.Q2: Validation of Analytical Procedures: Text and Methodology. 2005.

UNITED STATES OF AMERICA (U.S.A) International Conference on Harmonisation Guideline. Q8: Pharmaceutical Development. 2006.

UNITED STATES PHARMACOPEIA (USP): USP27; The National Formulary: NF22. Rockville: United States Pharmacopeial Convention, 2003. p.2622-2625.

URASAKI, M.B.M. et al. Práticas de exposição e proteção solar de jovens universitários. Revista Brasileira de Enfermagem, v. 69, n. 1, p. 126-133, 2016.

VELASCO, M.V.R. et al. Associação da rutina com p-metoxicinamato de octila e benzofenona-3: avaliação in vitro da eficácia fotoprotetora por espectrofotometria de refletância. Latin American Journal of Pharmacy, v.27, n.1, p.23-27, 2007.

VELASCO, M.V.R. et al. Broad spectrum bioactive sunscreens. International Journal of Pharmaceutics, v.363, n.1/2, p.50-57, 2008.

VELASCO, M.V.R. et al. Novas metodologias analíticas para avaliação da eficácia fotoprotetora (in vitro) - revisão. Revista de Ciências Farmacêuticas Básica e Aplicada, v. 32, n. 1, p. 27-34, 2011.

VICIOLLE, E.; CASTILHO, P.; ROSADO, C. In vitro and in vivo assessment of the effect of Laurus novo canariensis oil and essential oil in human skin. International journal of cosmetic science, v. 34, n. 6, p. 546-50, dez. 2012.

WANG, S. Q.; LIM, H. W. (Ed.). Principles and practice of photoprotection. United States of America. Springer International Publishing Switzerland, 2016. 
WIJEKOON, K. C. et al. The fate of pharmaceuticals, steroid hormones, phytoestrogens, UV-filters and pesticides during MBR treatment. Bioresource technology, v. 144, p. 247-254, 2013.

ZAMBON, A.P.L.B. Influência da associação de filtros solares sobre a estabilidade, liberação, permeação e retenção cutânea do p-metoxicinamato de octila em formulações fotoprotetoras. 2011. xx, 125 p. Dissertação (mestrado) Universidade Estadual Paulista, Faculdade de Ciências Farmacêuticas, 2011.

ZANON-MORENO $\mathrm{V}$. et al. Oxidative stress in primary open-angle glaucoma. Journal of glaucoma, v. 17, n. 4, p. 263-268, 2008.

ZEGARSKA, B. et al. Air pollution, UV irradiation and skin carcinogenesis: what we know, where we stand and what is likely to happen in the future?. Advances in Dermatology and Allergology/Postępy Dermatologii i Alergologii, v. 34, n. 1, p. 6, 2017. 


\section{ANEXOS}

\section{Anexo A - Currículo Lattes}

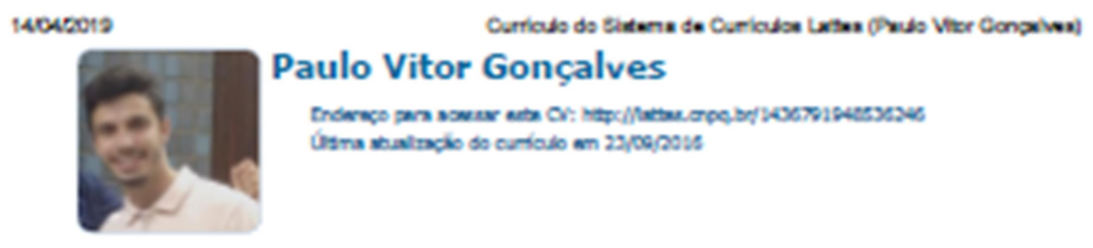

Tom exeriênch na śrea de Famsida, com botase em Pescuisa e Deservolvimento. (Texto informado pelo autce)

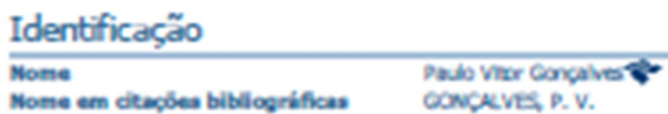

Endereşo

Formação acadêmica/titulação

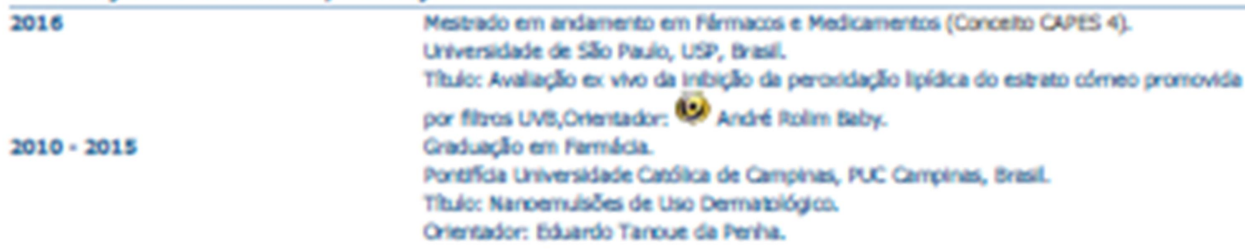

Formação Complementar

\begin{tabular}{|c|c|}
\hline $2015 \cdot 2015$ & 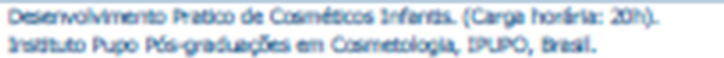 \\
\hline 2015 - 2015 & 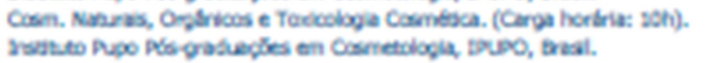 \\
\hline $2015 \cdot 2015$ & 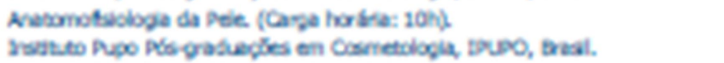 \\
\hline 2015 - 2015 & 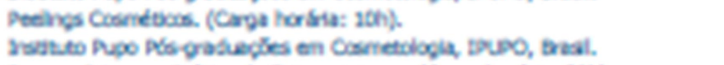 \\
\hline 2015 - 2015 & 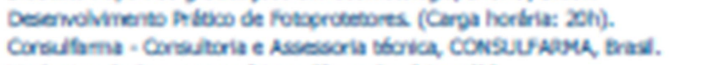 \\
\hline 2015 - 2015 & 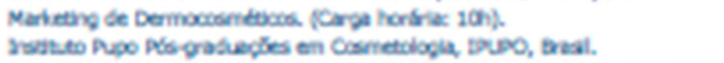 \\
\hline $2015 \cdot 2015$ & 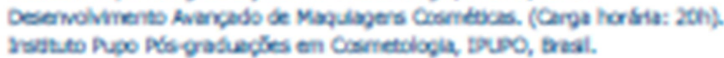 \\
\hline 2015 - 2015 & 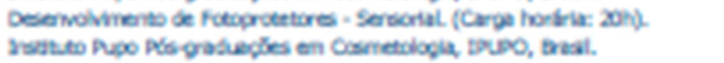 \\
\hline 2015 - 2015 & 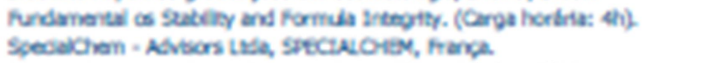 \\
\hline $2014 \cdot 2015$ & 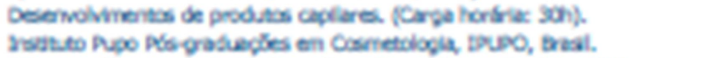 \\
\hline $2014 \cdot 2014$ & 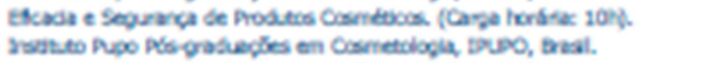 \\
\hline 2014 - 2014 & 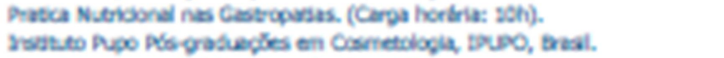 \\
\hline 2011 - 2011 & 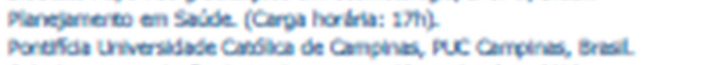 \\
\hline 2005 - 2000 & 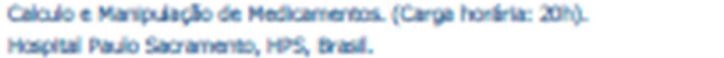 \\
\hline
\end{tabular}

Atuação Profissional 
Projetos de pesquisa

2012 - 2013 Caracterizaçăo e padronizaçăo de oleorresina de Copaifera ssp.
Descriç̆o: Bolsa de IC - FAPESP.
Situaç̆o: Conduido; Natureza: Pesquisa.
Nunos envolvidos: Graduaç̆o: (1) .

Integrantes: Paulo Vicor Gonçalves - Integrante / Carmen Luda Queiroga - Coordenador.

Áreas de atuação

Grande área: Cênclas da Saúde / Área: Farmácia.

\title{
Idiomas
}

Ingles

Compreende Razcavelmente, Fala Pouco, LA Razoavelmente, Escreve Pouco.

\section{Produções}

\author{
Produção bibliográfica
}

Pbina gerada pebo Sstema Curriculo Lattes em 14/04/2019 \&s 21:55:07 


\section{Anexo B - Informações para os membros de bancas julgadoras de Mestrado e Doutorado}

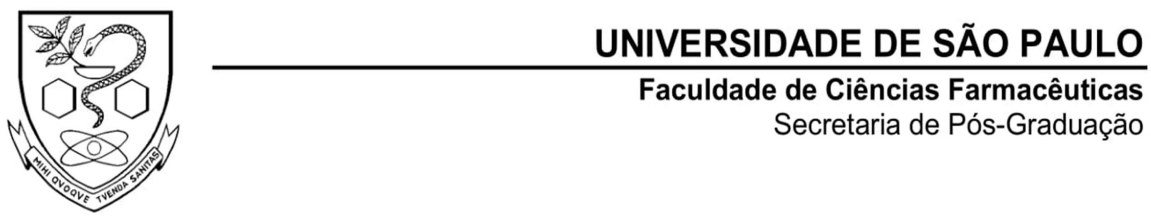

\section{Informações para os Membros de Bancas Julgadoras de Mestrado/Doutorado}

1. O candidato fará uma apresentação oral do seu trabalho, com duração máxima de trinta minutos.

2. Os membros da banca farão a arguição oral. Cada examinador disporá, no máximo, de trinta minutos para arguir o candidato, exclusivamente sobre o tema do trabalho apresentado, e o candidato disporá de trinta minutos para sua resposta.

2.1. Com a devida anuência das partes (examinador e candidato), é facultada a arguição na forma de diálogo em até sessenta minutos por examinador.

3. A sessão de defesa será aberta ao público.

4. Terminada a arguição por todos os membros da banca, a mesma se reunirá reservadamente e expressará na ata (relatório de defesa) a aprovação ou reprovação do candidato, baseando-se no trabalho escrito e na arguição.

4.1. Caso algum membro da banca reprove o candidato, a Comissão Julgadora deverá emitir um parecer a ser escrito em campo exclusivamente indicado na ata.

4.2. Será considerado aprovado o aluno que obtiver aprovação por unanimidade ou pela maioria da banca.

5. Dúvidas poderão ser esclarecidas junto à Secretaria de Pós-Graduação: pgfarma@usp.br, (11) 30913621.

São Paulo, 05 de maio de 2017.

Prof. Dr. João Roberto Oliveira do Nascimento Presidente da CPG/FCF/USP 


\section{ANEXO C - Ficha do Aluno - Paulo Vitor Gonçalves}

Janus - Sistema Administrativo da Pós-Graduação

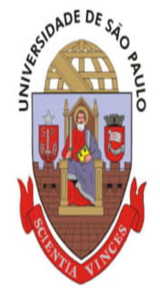

Universidade de São Paulo

Faculdade de Ciências Farmacêuticas

Documento sem validade oficial

FICHA DO ALUNO

9139 - 10083916/1 - Paulo Vitor Gonçalves

Email:

paulovigon@hotmail.com (favor indicar um email usp.br o mais rápido possivel)

Data de Nascimento:

27/12/1989

Cédula de Identidade:

RG - 16.432.585 - MG

Local de Nascimento:

Estado de Minas Gerais

Nacionalidade:

Brasileira

Graduação:

Farmacêutico - Pontificia Universidade Católica de Minas Gerais - Minas Gerais Brasil - 2016

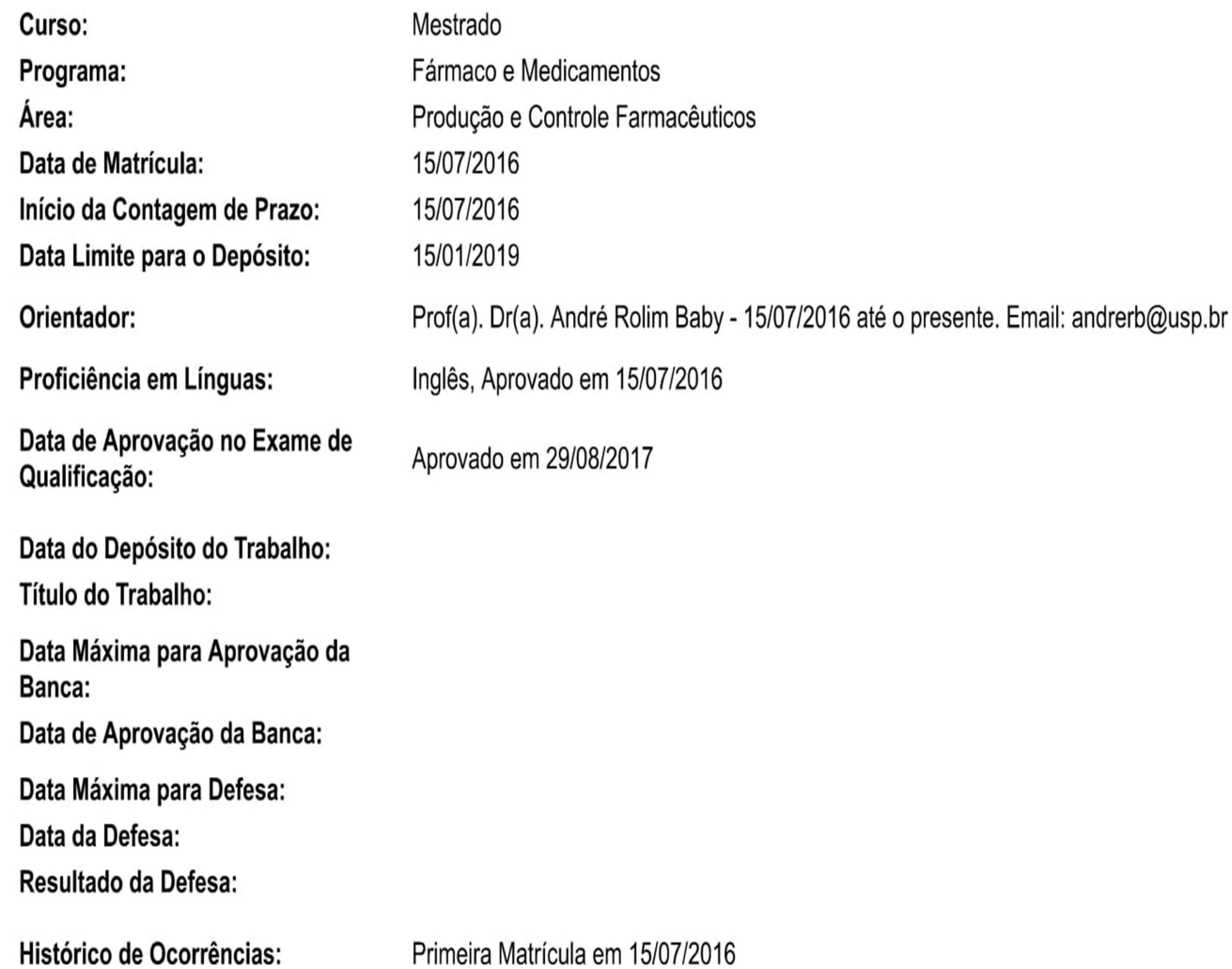

Orientador:

Proficiência em Línguas:

Prof(a). Dr(a). André Rolim Baby - 15/07/2016 até o presente. Email: andrerb@usp.br

Data de Aprovação no Exame de Qualificação: Inglês, Aprovado em 15/07/2016

Aprovado em 29/08/2017

Data do Depósito do Trabalho:

Título do Trabalho:

Data Máxima para Aprovação da

Banca:

Data de Aprovação da Banca:

Data Máxima para Defesa:

Data da Defesa:

Resultado da Defesa:

Histórico de Ocorrências:

Primeira Matrícula em 15/07/2016

Aluno matriculado no Regimento da Pós-Graduação USP (Resolução nº 6542 em vigor de 20/04/2013 até 28/03/2018).

Última ocorrência: Matrícula de Acompanhamento em 16/07/2018

Impresso em: 09/01/2019 01:29:14 
Janus - Sistema Administrativo da Pós-Graduação

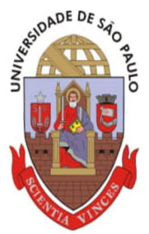

Universidade de São Paulo

Faculdade de Ciências Farmacêuticas

Documento sem validade oficial

FICHA DO ALUNO

9139 - 10083916/1 - Paulo Vitor Gonçalves

\begin{tabular}{|c|c|c|c|c|c|c|c|c|c|}
\hline Sigla & Nome da Disciplina & Início & Término & $\begin{array}{l}\text { Carga } \\
\text { Horária }\end{array}$ & Cred. & Freq & Conc & Exc & Situação \\
\hline $\begin{array}{l}\text { QBQ5893- } \\
1 / 1\end{array}$ & $\begin{array}{l}\text { - Processos Redox em Bioquímica (Instituto de } \\
\text { Quimica - Universidade de São Paulo) }\end{array}$ & $02 / 08 / 2016$ & $14 / 11 / 2016$ & 60 & 0 & 70 & $\mathrm{R}$ & $\mathrm{N}$ & Concluida \\
\hline $\begin{array}{l}\text { FBF5805- } \\
\quad 2 / 3\end{array}$ & $\begin{array}{l}\text { Delineamento de Experimentos e } \\
\text { Ferramentas Estatisticas Aplicadas às } \\
\text { Ciências Farmacêuticas }\end{array}$ & $11 / 08 / 2016$ & $19 / 10 / 2016$ & 90 & 6 & 100 & A & $\mathrm{N}$ & Concluída \\
\hline $\begin{array}{l}\text { FBF5777- } \\
3 / 7\end{array}$ & Tópicos Gerais de Fármaco e Medicamentos I & $11 / 08 / 2016$ & $23 / 11 / 2016$ & 45 & 3 & 93 & A & $\mathrm{N}$ & Concluída \\
\hline $\begin{array}{l}\text { FBF5712- } \\
7 / 2\end{array}$ & Introdução à Síntese de Fármacos & $06 / 03 / 2017$ & $15 / 05 / 2017$ & 150 & 0 & - & - & $\mathrm{N}$ & $\begin{array}{l}\text { Pré- } \\
\text { matrícula } \\
\text { recusada }\end{array}$ \\
\hline $\begin{array}{l}\text { FBF5704- } \\
\quad 6 / 5\end{array}$ & Análise Espectrométrica de Fármacos & $06 / 03 / 2017$ & $18 / 06 / 2017$ & 150 & 10 & 85 & A & $\mathrm{N}$ & Concluida \\
\hline $\begin{array}{l}\text { FBF5784- } \\
2 / 5\end{array}$ & $\begin{array}{l}\text { - Eletroforese Capilar: Princípios e Aplicações } \\
\text { na Área Farmacêutica }\end{array}$ & 08/03/2017 & $11 / 05 / 2017$ & 90 & 6 & 77 & A & $\mathrm{N}$ & Concluida \\
\hline
\end{tabular}

\begin{tabular}{|l|c|c|c|}
\hline \hline & \multicolumn{2}{|c|}{ Créditos mínimos exigidos } & Créditos obtidos \\
\hline & Para exame de qualificação & Para depósito da dissertação & \\
\hline Disciplinas: & 0 & 25 & 25 \\
\hline Estágios: & & & 25 \\
\hline Total: & 0 & 25 & 25 \\
\hline
\end{tabular}

Créditos Atribuídos à Dissertação: 71

Conceito a partir de 02/01/1997:

A - Excelente, com direito a crédito; B - Bom, com direito a crédito; C - Regular, com direito a crédito; R - Reprovado; T Transferência.

Um(1) crédito equivale a 15 horas de atividade programada.

Última ocorrência: Matrícula de Acompanhamento em 16/07/2018

Impresso em: 09/01/2019 01:29:15 


\title{
Anexo D - Parecer Consubstanciado do Comitê de Ética em Pesquisa
}

USP - FACULDADE DE
CIÊNCIAS FARMACÊUTICAS Plotoforma
DA UNIVERSIDADE DE SÃO

\section{PARECER CONSUBSTANCIADO DO CEP}

\section{DADOS DO PROJETO DE PESQUISA}

Título da Pesquisa: Avaliação ex vivo da inibição da peroxidação lipídica do estrato córneo promovida por filtros UVB

Pesquisador: André Rolim Baby

Área Temática:

Versão: 2

CAAE: 61716316.4 .0000 .0067

Instituição Proponente: Faculdade de Ciências Farmacêuticas da Universidade de São Paulo

Patrocinador Principal: Financiamento Próprio

\section{DADOS DO PARECER}

Número do Parecer: 1.996 .575

\begin{abstract}
Apresentação do Projeto:
O aumento da incidência de câncer de pele está associado à maior exposição à luz solar e a inclusão de ações de proteção ao Sol é uma estratégia relevante de minimizar os níveis cumulativos de exposição à radiação. Os raios ultravioleta (UV), ao alcançarem a pele, podem causar eritema, inflamação, fotoenvelhecimento, formação de rugas e imunossupressão devido à formação de espécies reativas de oxigênio (ERO's). A formação de ERO's, como o oxigênio singleto, radical ânion superóxido, peroxido de hidrogênio e radical hidroxil elevam o risco dos danos fotooxidativos. $O$ desequilíbrio entre a formação de ERO's e os mecanismos antioxidantes do organismo desencadeia o estresse oxidativo. Na pele, as ERO's são as responsáveis pelo dano oxidativo no DNA, proteínas e lipídeos. Identificar e quantificar biomarcadores do estresse oxidativo cutâneo é essencial para a correta correlação entre os raios UV e seus efeitos. Deve-se isto, em parte, à limitação de métodos para quantificar os parâmetros que são diretamente afetados pela exposição aos raios UV, tais como a peroxidação lipídica. São necessários métodos complementares para avaliação da eficácia de fotoprotetores perante os danos

causados pelo estresse oxidativo. A proposta do projeto compreende a avaliação ex vivo da
\end{abstract}

Endereço: Av. Prof. Lineu Prestes, 580, Bloco 13A, sala 112

Bairro: Butantã CEP: $05.508-000$

UF: SP Município: SAO PAULO

Telefone: (11)3091-3622 Fax: (11)3031-8986 E-mail: cepfcf@usp.br 


\section{USP - FACULDADE DE CIÊNCIAS FARMACÊUTICAS DA UNIVERSIDADE DE SÃO

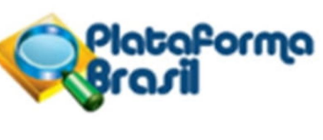

Continuação do Parecer: 1.996 .575

eficácia de filtros solares UVB, inseridos em formulações O/A, por meio da quantificação da peroxidação lipídica proveniente do estrato córneo removido

por tape-stripping. Os resultados permitirão determinar a efetividade de um método ex vivo, menos invasivo, para a determinação da eficácia de protetores solares e quantificação dos produtos resultantes da peroxidação lipídica.

\section{Objetivo da Pesquisa:}

Objetivos gerais:

A proposta do projeto compreende a avaliação ex vivo da eficácia de filtros solares UVB por meio da quantificação da peroxidação lipídica proveniente do estrato córneo removido por tape-stripping.

Objetivos específicos:

O projeto de pesquisa apreciará atingir as seguintes metas:

(i) preparo de amostras em veículo emulsionado (emulsão O/A) contendo p-metoxicinamato de octila, salicilato de octila ou octocrileno;

(ii) caracterização física, físico-química, estabilidade preliminar e eficácia funcional in vitro das preparaçõespor espectrofotometria de refletância difusa com esfera de integração;

(iii) validação de método analítico por cromatografia à líquido de alta eficiência para a quantificação da peroxidação lipídica; e

(iv) determinação da eficácia ex vivo dos filtros solares UVB por meio do doseamento da lipoperoxidação a partir do estrato córneo obtido por tape-stripping.

\section{Avaliação dos Riscos e Benefícios:}

Os pesquisadores declaram:

RISCOS: reações inesperadas, decorrentes da aplicação tópica do(s) produto(s)

em teste, podem ocorrer, incluindo dermatites de contato e/ou alérgica com intensidades variáveis, podendo ser graves.

Garantimos que os cuidados e acompanhamento necessários serão fornecidos pelos pesquisadores durante todas as etapas do estudo. Em caso de reações adversas que necessitem de acompanhamento ambulatorial e/ou internação, os responsáveis pela pesquisa lhe acompanharão até uma unidade de saúde do Sistema Único de Saúde-SUS, que apresenta infraestrutura adequada para qualquer tratamento que se faça necessário. Garantimos que todas as despesas decorrentes do eventual

Endereço: Av. Prof. Lineu Prestes, 580, Bloco 13A, sala 112

Bairro: Butantã CEP: $05.508-000$

UF: SP Municipio: SAO PAULO

Telefone: (11)3091-3622 Fax: (11)3031-8986_ E-mail: cepfc@@usp.b 


\section{USP - FACULDADE DE CIÊNCIAS FARMACÊUTICAS DA UNIVERSIDADE DE SÃO}

Continuação do Parecer: 1.996 .575

tratamento

serão arcadas, de forma integral, pelos responsáveis por esta pesquisa.

BENEFÍCIOS:

Você não obterá nenhum benefício financeiro e à sua saúde, pois este é um produto cosmético. Noentanto, você estará ajudando, como participante desta pesquisa, a ampliar o conhecimento sobre a segurança e eficácia de produtos cosméticos.

\section{Comentários e Considerações sobre a Pesquisa:}

Trata-se de Projeto de Pesquisa de Mestrado, do aluno: Paulo Vitor Gonçalves, com a orientação do Prof. Dr. André Rolim Baby

As estratégias para prevenir e proteger a pele contra os danos causados pela exposição solar estão se expandindo, porém, a eficácia destas pode ser insatisfatória. Identificar e quantificar biomarcadores do estresse oxidativo na pele é essencial para a correta correlação entre os raios UV e seus efeitos. Existe uma ampla investigação sobre os efeitos de danos UV e tratamentos à nível celular. Entretanto, há diferentes métodos de quantificar os efeitos de danos induzidos por UV na pele. Deve-se isto, em parte, à falta de métodos para quantificar os parâmetros que são diretamente afetados pela exposição aos raios UV, tais como a peroxidação de lipídeos, alteração na quantidade de antioxidantes, atividade de enzimas antioxidantes e produtos da oxidação de proteínas e do DNA. Portanto, apesar do uso de protetores solares ser uma realidade irretorquível, existe a necessidade de métodos complementares para a comprovação mais abrangente da eficácia desta classe de produtos. São necessários métodos para avaliação da eficácia de fotoprotetores perante os danos causados pelo estresse oxidativo.

Os resultados deste projeto apresentarão perspectivas de aplicação prática na área de pesquisa

Endereço: Av. Prof. Lineu Prestes, 580, Bloco 13A, sala 112

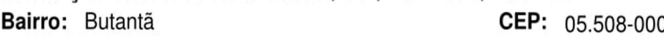

E-mail: cepfcf@usp.br 


\section{USP - FACULDADE DE CIÊNCIAS FARMACÊUTICAS DA UNIVERSIDADE DE SÃO

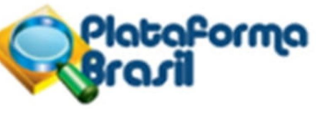

Continuação do Parecer: 1.996 .575

clínica de

produtos cosméticos fotoprotetores, agregando novo método,

menos invasivo, a ser empregado para a análise complementar da eficácia

fotoprotetora. O método para a determinação da eficácia ex vivo de fotoprotetores é inovador e não há aplicabilidade da técnica de TBARS para este tipo de análise. A subsequente divulgação científica irá estimular a criação e consolidação de novas linhas de pesquisa no presente segmento, além de contribuição técnico-científica relevante na Área Cosmética.

Considerações sobre os Termos de apresentação obrigatória:

Todos foram apresentados.

Recomendações:

As recomendações foram atendidas, sem novas recomendações.

Conclusões ou Pendências e Lista de Inadequações:

Sem pendências.

Considerações Finais a critério do CEP:

Aprovado ad referendum.

Este parecer foi elaborado baseado nos documentos abaixo relacionados:

\begin{tabular}{|c|c|c|c|c|}
\hline Tipo Documento & Arquivo & Postagem & Autor & Situação \\
\hline $\begin{array}{l}\text { Informações Básicas } \\
\text { do Projeto }\end{array}$ & $\begin{array}{l}\text { PB_INFORMAÇŌES_BÁSICAS_DO_P } \\
\text { ROJETO 799709.pdf }\end{array}$ & $\begin{array}{c}29 / 03 / 2017 \\
00: 36: 46 \\
\end{array}$ & & Aceito \\
\hline Outros & CartadeEsclarecimento.pdf & $\begin{array}{c}29 / 03 / 2017 \\
00: 35: 31 \\
\end{array}$ & $\begin{array}{l}\text { PAULO VITOR } \\
\text { GONCALVES } \\
\end{array}$ & Aceito \\
\hline $\begin{array}{l}\text { Declaração de } \\
\text { Pesquisadores }\end{array}$ & Participacao.pdf & $\begin{array}{c}03 / 11 / 2016 \\
16: 34: 34 \\
\end{array}$ & $\begin{array}{l}\text { PAULO VITOR } \\
\text { GONCALVES } \\
\end{array}$ & Aceito \\
\hline $\begin{array}{l}\text { TCLE / Termos de } \\
\text { Assentimento / } \\
\text { Justificativa de } \\
\text { Ausência } \\
\end{array}$ & TCLE.pdf & $\begin{array}{c}27 / 09 / 2016 \\
14: 35: 00\end{array}$ & $\begin{array}{l}\text { PAULO VITOR } \\
\text { GONCALVES }\end{array}$ & Aceito \\
\hline Folha de Rosto & FolhaRosto.pdf & $\begin{array}{c}27 / 09 / 2016 \\
14: 33: 40 \\
\end{array}$ & $\begin{array}{l}\text { PAULO VITOR } \\
\text { GONCALVES } \\
\end{array}$ & Aceito \\
\hline $\begin{array}{l}\text { Projeto Detalhado / } \\
\text { Brochura } \\
\text { Investigador }\end{array}$ & Projeto.pdf & $\begin{array}{l}27 / 09 / 2016 \\
14: 32: 44\end{array}$ & $\begin{array}{l}\text { PAULO VITOR } \\
\text { GONCALVES }\end{array}$ & Aceito \\
\hline
\end{tabular}

Endereço: Av. Prof. Lineu Prestes, 580, Bloco 13A, sala 112

Bairro: Butantã

UF: SP

CEP: $05.508-000$

Município: SAO PAULO

Fax: (11)3031-8986 E-mail: cepfcf@usp.b 


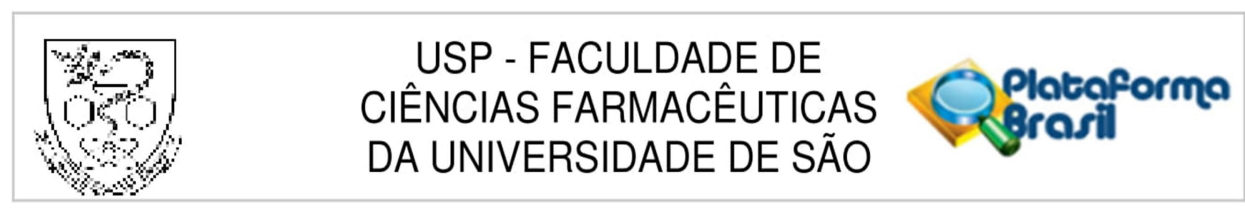

Continuação do Parecer: 1.996 .575

Situação do Parecer:

Aprovado

Necessita Apreciação da CONEP:

Não

SAO PAULO, 03 de Abril de 2017

Assinado por:

Cristina Northfleet de Albuquerque

(Coordenador)

Endereço: Av. Prof. Lineu Prestes, 580, Bloco 13A, sala 112

Bairro: Butantã

UF: SP

Município: SAO PAULO

Telefone: (11)3091-3622

Fax: (11)3031-8986

E-mail: cepfcf@usp.br 


\title{
Anexo E - Termo de Consentimento Livre e Esclarecido (TCLE) para a Avaliação ex vivo de Peroxidação Lipídica
}

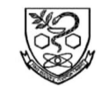 \\ Universidade de São Paulo \\ Faculdade de Ciências Farmacêuticas \\ TERMO DE CONSENTIMENTO LIVRE E ESCLARECIDO - TCLE \\ AVALIAÇÃO EX VIVO DA PEROXIDAÇÃO LIPÍDICA
}

1. Informações do Participante da Pesquisa (para preenchimento)

Nome:

Documento de Identidade (número): Sexo: ( ) M ( ) F

Local de Nascimento: Data de Nascimento:

Endereço:

Complemento: Bairro: CEP:

Cidade: Estado:

Telefone (residencial): Telefone (celular):

\section{Dados sobre a Pesquisa}

Título da Pesquisa: Avaliação ex vivo da inibição da peroxidação lipídica do estrato córneo promovida por filtros UVB

Pesquisador Responsável: Dr. André Rolim Baby / fone: (11) 3091-2358 e (11) 94225-0033

- Professor Doutor da Universidade de São Paulo (Faculdade de Ciências Farmacêuticas)

Pesquisador Associado: Paulo Vitor Gonçalves / fone: (11) 4496-2398 e (11) 97631-6044

- Pesquisador da Universidade de São Paulo (Faculdade de Ciências Farmacêuticas)

\section{Duração da Pesquisa: 1 dia}

Risco da Pesquisa: Mínimo

\section{Faixa etária dos participantes da pesquisa: de 18 a 60 anos}

Você está sendo convidado a participar de uma pesquisa que tem como objetivo avaliar a eficácia de filtros solares UVB através do estrato córneo removido por tape-stripping. 0 estrato córneo (camada mais superficial da pele), será retirado através de um procedimento simples que consiste na adesão de uma fita adesiva específica na superfície da pele limpa e posterior retirada (tape-strippimg). Pedimos que leia detalhadamente este Termo de Consentimento e, apenas se concordar com os itens mencionados, assine-o em duas vias (uma delas será entregue a você). Todas as dúvidas surgidas durante ou após o estudo serão prontamente esclarecidas.

Para a realização deste estudo, você comparecerá ao local da pesquisa em apenas um dia, permanecendo no local por um período de aproximadamente seis horas. Nesse dia, será realizada uma avaliação clínica da sua pele, com posterior aplicação do(s) produto(s) em teste em seu antebraço. Serão realizadas duas aplicações do(s) produto(s), sempre no mesmo local, com intervalos de duas horas entre cada aplicação. 


\section{050
28 \\ Universidade de São Paulo \\ Faculdade de Ciências Farmacêuticas \\ TERMO DE CONSENTIMENTO LIVRE E ESCLARECIDO - TCLE \\ AVALIAÇÃO EX VIVO DA PEROXIDAÇÃO LIPÍDICA}

Após duas horas da última aplicação, serão realizadas aplicações sucessivas de fitas adesivas, com o objetivo de remover a camada superficial da pele nas áreas de aplicação do(s) produto(s) em teste, com desconforto mínimo.

Adicionalmente, uma área virgem do antebraço (não utilizada para a aplicação do(s) produto(s) em teste) será utilizada como controle do estudo, e também receberá aplicações sucessivas de fitas adesivas, com o objetivo de remover a camada superficial da pele.

Após esta etapa, você poderá deixar as dependências do local da pesquisa. Os adesivos removidos serão posteriormente avaliados, por pesquisadores treinados, para determinação da peroxidação lipídica da(s) amostra(s) aplicada(s) (áreas de aplicação).

Solicitamos que durante o período de estudo (incluindo três dias antes do início do ensaio e três dias após a sua finalização) você não altere seus hábitos de higiene, dieta, medicamentos, cosméticos e exercícios; não se exponha excessivamente ao sol; e não aplique qualquer produto no local de realização do teste.

Todas as substâncias que compõem o produto são de uso habitual, na forma de aplicação proposta, e consideradas seguras para a finalidade que se destinam. No entanto, ainda que raras, ressaltamos que reações inesperadas, decorrentes da aplicação tópica do(s) produto(s) em teste, podem ocorrer, incluindo dermatites de contato e/ou alérgica com intensidades variáveis, podendo ser graves.

Garantimos que os cuidados e acompanhamento necessários serão fornecidos pelos pesquisadores durante todas as etapas do estudo. Caso você necessite de assistência médica ou esclarecimento, favor entrar em contato com Dr. André Rolim Baby / fone: (11) 3091-2358 e (11) 94225-0033 e ou Paulo Vitor Gonçalves / fone: (11) 4496-2398 e (11) 97631-6044.

Em caso de reações adversas que necessitem de acompanhamento ambulatorial e/ou internação, os responsáveis pela pesquisa lhe acompanharão até uma unidade de saúde do Sistema Único de Saúde-SUS, que apresenta infraestrutura adequada para qualquer tratamento que se faça necessário. Garantimos que todas as despesas decorrentes do eventual tratamento serão arcadas, de forma integral, pelos responsáveis por esta pesquisa.

Você não obterá nenhum benefício financeiro e à sua saúde, pois este é um produto cosmético. No entanto, você estará ajudando, como participante desta pesquisa, a ampliar o conhecimento sobre a segurança e eficácia de produtos cosméticos. Garantimos que as suas despesas, decorrentes exclusivamente da participação nesta pesquisa, serão completamente ressarcidas. Eventuais danos decorrentes da sua participação serão indenizados.

Todas as informações obtidas e declaradas por você serão tratadas de maneira confidencial, sendo que apenas as pessoas diretamente ligadas a este estudo e autoridades legais poderão ter acesso, sem com isso, violar a confidencialidade. Se os resultados do estudo forem publicados, sua identidade continuará sendo preservada. 
Universidade de São Paulo Faculdade de Ciências Farmacêuticas

\section{TERMO DE CONSENTIMENTO LIVRE E ESCLARECIDO - TCLE AVALIAÇÃO EX VIVO DA PEROXIDAÇÃO LIPÍDICA}

Você pode retirar sua participação a qualquer momento do estudo, comunicando sua desistência ao pesquisador responsável pelo seu acompanhamento, sem que isso acarrete qualquer consequência negativa a você.

\section{Consentimento Pós-Esclarecido}

Declaro que, após ter sido convenientemente esclarecido pelo pesquisador e ter entendido 0 que me foi explicado, consinto em participar do presente Protocolo de Pesquisa.

São Paulo, de de

Assinatura do Participante de Pesquisa

Assinatura do Pesquisador Responsável

Para qualquer questão, dúvida, esclarecimento ou reclamação sobre aspectos éticos relativos a este protocolo de pesquisa, favor entrar em contato com o Comitê de Ética em Pesquisa da Faculdade de Ciências Farmacêuticas da Universidade de São Paulo: Av. Prof. Lineu Prestes, 580, Bloco 13 A, Butantã, São Paulo, CEP: 05508-000, telefones (11) 3091-3622 e (11) 3091-3677, e-mail: cepfcf@usp.br. 